Chemical Technology

ANL-01/33

Division

Chemical Technology

Division

Chemical Technology

Division

Chemical Technology

Chemical Technology

Division

Chemical Technology

Division

Chemical Technology

Division

Chemical Technology

Division

Chemical Technology

Division

Chemical Technology

Division

Chemical Technology

Division

Chemical Technology

Division

Chemical Technology

Division

Chemical Technology

Division

Chemical Technology

Division

Chemical Technology

Division

\title{
Batch Tests with Unirradiated Uranium Metal Fuel Program Report
}

by M. D. Kaminski

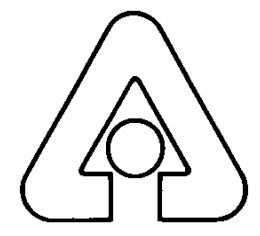

Argonne National Laboratory, Argonne, Illinois 60439

operated by The University of Chicago

for the United States Department of Energy under Contract W-31-109-Eng-38

Chemical Technology

Division

Chemical Technology

Division

Chemical Technology

Division

Chemical Technology

Division 
Argonne National Laboratory, with facilities in the states of Illinois and Idaho, is owned by the United States Government and operated by The University of Chicago under the provisions of a contract with the Department of Energy.

\section{DISCLAIMER}

This report was prepared as an account of work sponsored by an agency of the United States Government. Neither the United States Government nor any agency thereof, nor The University of Chicago, nor any of their employees or officers, makes any warranty, express or implied, or assumes any legal liability or responsibility for the accuracy, completeness, or usefulness of any information, apparatus, product, or process disclosed, or represents that its use would not infringe privately owned rights. Reference herein to any specific commercial product, process, or service by trade name, trademark, manufacturer, or otherwise, does not necessarily constitute or imply its endorsement, recommendation, or favoring by the United States Government or any agency thereof. The views and opinions of document authors expressed herein do not necessarily state or reflect those of the United States Government or any agency thereof, Argonne National Laboratory, or The University of Chicago.

Available electronically at http://www.doe.gov/bridge

Available for a processing fee to U.S. Department of Energy and its contractors, in paper, from:

U.S. Department of Energy

Office of Scientific and Technical Information

P.O. Box 62

Oak Ridge, TN 37831-0062

phone: (865) 576-8401

fax: (865) 576-5728

email: reports@adonis.osti.gov 


\section{ANL-01/33 \\ ARGONNE NATIONAL LABORATORY \\ 9700 South Cass Avenue \\ Argonne, IL 60439}

\section{Batch Tests with Unirradiated Uranium Metal Fuel Program Report}

By

M. D. Kaminski

Chemical Technology Division

December 2001 


\section{TABLE OF CONTENTS}

$\underline{\text { Page }}$

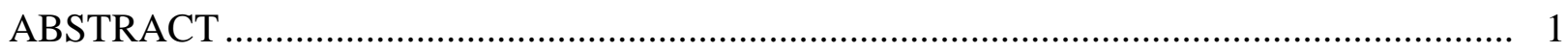

I. INTRODUCTION AND BACKGROUND .............................................................. 1

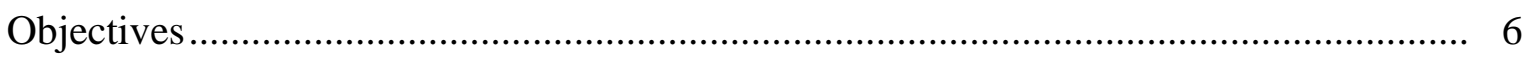

II. EXPERIMENTAL AND TECHNICAL APPROACH................................................ 6

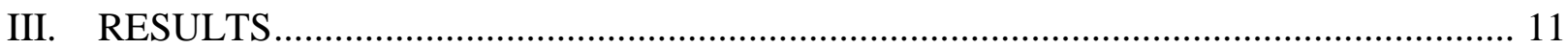

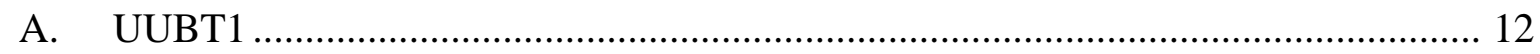

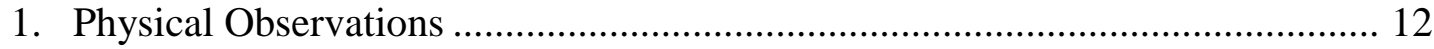

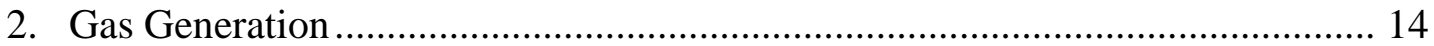

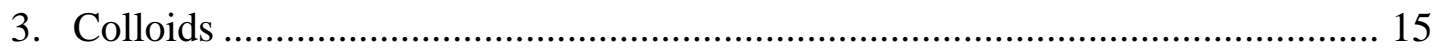

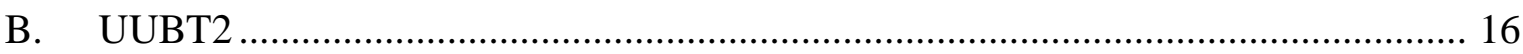

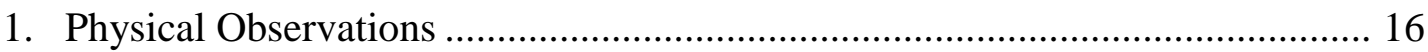

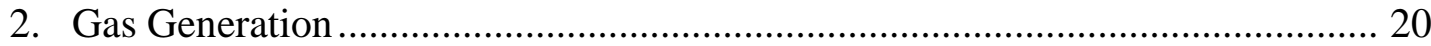

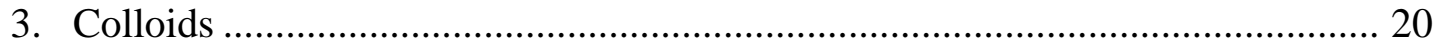

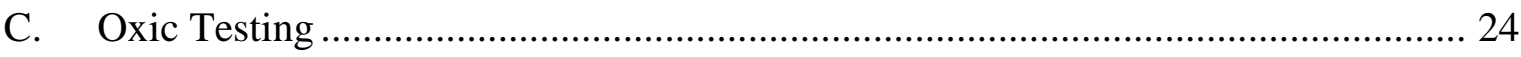

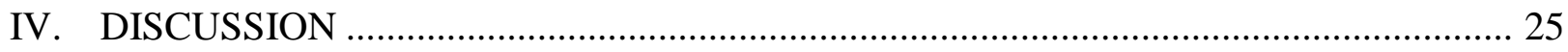

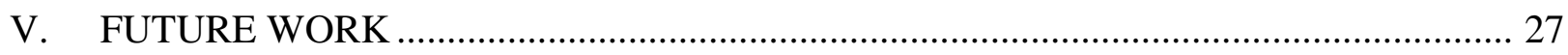

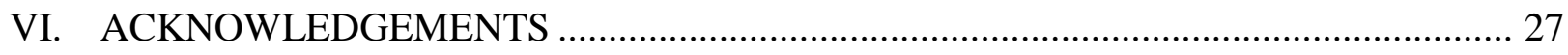

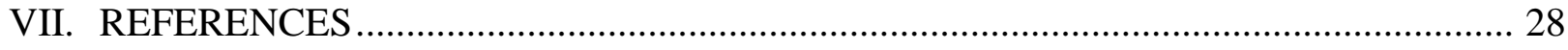

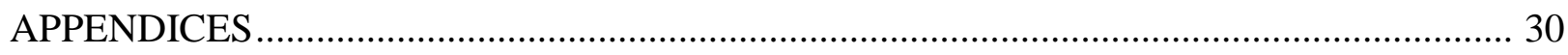

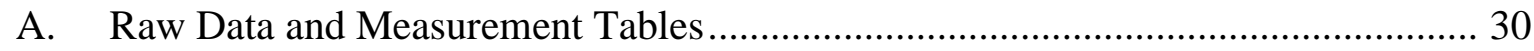

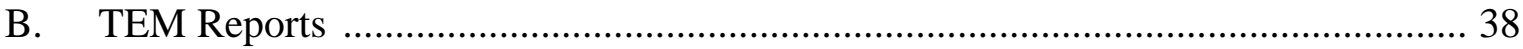




\section{LIST OF FIGURES}

$\underline{\text { Page }}$

1. Oxidation Rate of Metallic Uranium as a Function of Oxygen Partial

Pressure

2. Experimental Test Components ....................................................................... 9

3. Controlled Atmosphere Containment Box Developed for Metallic Uranium

Batch Testing Program

4. Measured $\mathrm{O}_{2}$ Concentrations in the Controlled Atmosphere Containment

Box as a Function of Time Following Opening of the Gloveport.

5. Spallation Products from the Corrosion of Metallic Uranium Fuel after

45 Days

6. The Inferred $\mathrm{H}_{2}$ Gas Produced during the Corrosion of $98.4 \mathrm{mg}$ of Uranium Metal in Test UUBT1

7. Optical Microscopic Image of the Partially Oxidized Fuel and Spalled Products Found at the Bottom of the Test Vessel

8. SEM Images of Suspended Uranium Oxides Found in Test UUBT2 at 55 Days

9. X-ray Diffraction Pattern for Oxidized Uranium Metal in EJ-13 at $90^{\circ} \mathrm{C}$

10. The Inferred $\mathrm{H}_{2}$ Gas Produced during the Corrosion of $84.1 \mathrm{mg}$ of Uranium Metal in Test UUBT2.

11. Dissolved and Colloid Uranium Concentrations in Solutions from Test UUBT2

12. TEM of Two Types of Colloids Found during Test UUBT2. 23

13. Transmission Electron Micrographs of Calcium-Rich Colloids Collected at 115 Days under Oxic Conditions in Test UUBT2 


\section{LIST OF TABLES}

$\underline{\text { Page }}$

1. Reaction Rates for Uranium Oxidation under Various Conditions............................ 6

2. Elemental Concentration for Deaerated EJ-13 Water Used in the

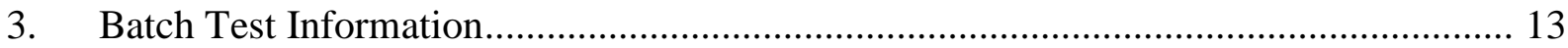

4. Light Scattering Intensity for Samples Withdrawn during Test UUBT1 .................... 16

5. Diffraction Peaks Identified for Oxidized Uranium Metal ....................................... 18

6. Measured Light Scattering Intensity for Samples Withdrawn during Test

UUBT2.

A1. Raw ICP-MS Data as Received from Analysis Report

RFA\# I-010104-1

A2. Raw ICP-MS Data as Received from Analysis Report

RFA\# I-010327-3

A3. Raw ICP-MS Data as Received from Analysis Report

RFA\# I-010327-3

A4. Raw ICP-MS Data as Received from Analysis Report

RFA\# I-010620-1

A5. Test Vessel Pressure Measurements Used to Estimate Uranium Oxidation

Rates for Test UUBT1

A6. Test Vessel Pressure Measurements Used to Estimate Uranium Oxidation

Rates for Test UUBT2.

A7. Analysis and Cell Parameters for X-Ray Diffraction of Oxidized Uranium Metal from Test UUBT2 Day 108

A8. Analysis and Cell Parameters for X-Ray Diffraction of Silicon

Powder Standard 


\begin{abstract}
Although the general environment of the proposed repository at Yucca Mountain is expected to be oxidizing in nature, the local chemistry within fuel canisters may be otherwise. The combination of low dissolved oxygen and corrosion of metallic fuels, such as Hanford's N-Reactor inventory, may produce reducing conditions. This condition may persist for periods sufficient to affect the corrosion and paragenesis of fuels and their reaction products. Starting in September 2001, unirradiated metallic uranium fuel was examined during batch tests under anoxic conditions. A series of tests carried out under inert atmosphere highlighted the rapid corrosion of the metallic uranium in EJ-13 water at $90^{\circ} \mathrm{C}$. During the oxidation of the uranium, uranium dioxide fines spalled from the fuel surface generating copious amounts of colloids. The proportion of uraniumassociated colloids accounted for nearly $50 \%$ to $>99 \%$ of the uranium in solution after a brief period where no colloids were detected. The colloids were identified as individual $(<10 \mathrm{~nm})$ and agglomerated uranium dioxide spheres as large as a few hundred nanometers in size. Silicate and alumino-silicate clays of diverse size and shape were also identified. The bulk size distribution as measured by dynamic light scattering was consistent with the microscopy observations in that the polydispersity indices were large, indicating a wide distribution of colloid particle sizes. The colloids were found to persist for periods beyond the scope of these tests and are at least partly stable. The anoxic experiments suggest that at least two mechanisms are responsible for uranium corrosion. The initial corrosion period is variably long but may last more than one month during which there is no net release of gas. Calculations of oxygen concentration in the vessel at the time of vessel closure show that this period is not consistent with the presence of dissolved oxygen, which would suppress $\mathrm{H}_{2}$ production in undersaturated conditions. After this induction period, the fuel begins to produce $\mathrm{H}_{2}$ gas until the coupon completely disaggregates into fine $\mathrm{UO}_{2+x}$ powder.
\end{abstract}

\title{
I. INTRODUCTION AND BACKGROUND
}

Although the general environment of the proposed repository at Yucca Mountain is expected to be oxidizing in nature, the local chemistry within fuel canisters may not be so. One can envision a scenario by which a fuel canister is breached thus allowing moisture to enter. Moisture reacting with metallic uranium fuels would deplete the available oxygen and may produce oxygen-starved conditions. These anoxic conditions may persist for periods sufficient to affect the corrosion and paragenesis of fuels and their corrosion products. The corrosion products are expected to come in contact with oxic conditions following their transport from the waste canister or potentially within the canister as a result of changing conditions. The changes brought about by the oxic front may be important.

It is has been well documented that the rate of uranium metal corrosion (i.e., $\mathrm{U} \rightarrow \mathrm{UO}_{2}$ ) is inversely dependent on the dissolved oxygen concentration and can accelerate by an order of magnitude at very low dissolved oxygen concentrations (see Fig. 1). Recently, we began 
hydrologically unsaturated, drip testing of the irradiated uranium metal fuel (N-Reactor) in air and the results show that a significant quantity of colloids is generated during oxidation. It is unknown whether colloids would also be generated under reducing conditions and at what number density or rate. In addition, fission product and actinide disposition in an anoxic environment may be different from that in oxic tests.

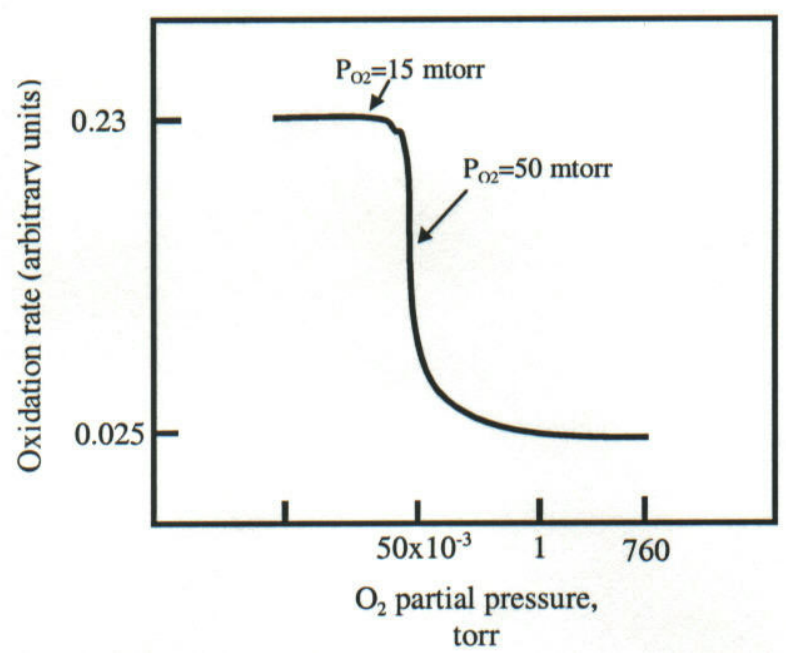

Fig. 1. Oxidation Rate for Metallic Uranium as a Function of Oxygen Partial Pressure [COLMENARES-1984]

Haschke summarizes the data [HASCHKE-1998] from a number of reviews on the oxidation characteristics of uranium metal. The oxidation of the surface is characterized by two distinct stages where the corrosion is limited by the diffusion of oxygen through the surface layer. The corrosion rate during the initial parabolic stage decreases as the thickness of the oxide layer grows. Following that, spalling of the oxide layer occurs and a constant effective layer thickness is achieved producing a linear rate of corrosion. The general corrosion rate $R_{U}$ is quantified as

$$
\mathrm{R}_{U}=k\left(\mathrm{P}_{O_{2}}\right)^{m}\left(\mathrm{P}_{H_{2} O}\right)^{n} \mathrm{e}^{\left(-E_{a} / R T\right)}
$$

where $k$ is the rate constant, $m$ and $n$ are empirical constants, $P$ is the pressure, $R$ is the gas constant, and $E_{a}$ is the energy of activation. In general, $m$ is negative and $n$ is positive; thus under most conditions, $\mathrm{O}_{2}$ and $\mathrm{H}_{2} \mathrm{O}$ compete to suppress and enhance the corrosion of the metal, respectively. Of note, at low oxygen pressures ( $P_{O_{2}}<15 \mathrm{mtorr}$ or $\left.20 \mathrm{ppm}\right), m=0$ and the rate is dependent only on the $\mathrm{H}_{2} \mathrm{O}$ pressure. Under humid conditions at $100{ }^{\circ} \mathrm{C}$, the uranium metal surface will be saturated with sorbed water and $R$ will be independent of water pressure or $n=0$. Under oxygen-free conditions the spalled products are large flakes free of hydride and determined to be $\mathrm{UO}_{2}$ and $\mathrm{UO}_{3} \cdot \mathrm{H}_{2} \mathrm{O}$ [HASCHKE-1998]. This disagrees with Ritchie's results [RITCHIE-1981], which state that oxygen is needed for trioxide formation. The overall reactions for wet oxidation in the absence of oxygen is expressed as, 


$$
\mathrm{U}+(2+\chi) \mathrm{H}_{2} \mathrm{O} \rightarrow \mathrm{UO}_{2+\chi}+(2+\chi) \mathrm{H}_{2}
$$

and with oxygen present,

$$
\begin{aligned}
& \mathrm{U}+\mathrm{H}_{2} \mathrm{O}+\mathrm{O}_{2} \rightarrow \mathrm{UO}_{2}+\mathrm{H}_{2} \mathrm{O} \\
& \mathrm{U}+\frac{2+\chi}{2} \mathrm{O}_{2} \rightarrow \mathrm{UO}_{2+\chi}
\end{aligned}
$$

where $x<0.25$. Oxidation in dry atmosphere produces strongly adherent black films, while wet oxidation produces a fine, loose black powder. Wet oxidation in the presence of $\mathrm{O}_{2}$ produces sheets of oxide that spall off once a critical thickness is reached $(\sim 1 \mu \mathrm{m})$. Baker et al. [BAKER1966] showed that oxygen concentration decreases linearly with time and that almost no $\mathrm{H}_{2}$ is produced until all the oxygen is consumed. They postulated that uranium hydride $\left(\mathrm{UH}_{3}\right)$ formed during anoxic corrosion in a closed system, which explained the slight decrease in $\mathrm{H}_{2}$ detected during experimentation.

The role of water in Eq. 2 needs clarification. Many researchers have tackled the problem of mechanistically determining uranium oxidation in undersaturated conditions $(<90 \%$ relative humidity). Baker et al. [BAKER-1966] argued that wet oxidation in the absence of oxygen follows a mechanism by which hydroxyls are formed at the oxide surface $\left(\mathrm{OH}_{\mathrm{s}}^{-}\right)$and diffuse into the lattice, converting uranium into its oxide as follows,

$$
\begin{aligned}
& \mathrm{H}_{2} \mathrm{O}(\mathrm{g}) \rightarrow \mathrm{H}_{\mathrm{s}}^{+}+\mathrm{OH}_{\mathrm{s}}^{-} \\
& \mathrm{U}+\mathrm{OH}_{\mathrm{s}}^{-} \rightarrow \mathrm{U}^{4+}+3 \mathrm{e}^{-}+\mathrm{O}_{\mathrm{s}}^{2-}+\mathrm{H}_{\mathrm{s}}
\end{aligned}
$$

The fate of the hydrogen radicals may involve hydrogen gas generation or hydride formation.

$$
\begin{aligned}
& 2 \mathrm{H} \cdot \rightarrow \mathrm{H}_{2} \\
& \underset{\mathrm{s}}{3 \mathrm{H} \cdot \mathrm{U}} \rightarrow \mathrm{UH}_{3}
\end{aligned}
$$

When oxygen is present, the reaction rate is reduced because of parasitic adsorption of $\mathrm{O}_{2}$ onto reaction sites on the corroding uranium. The $\mathrm{O}_{2}$ in this model converts hydrogen species produced by Eqs. 4 and 5 into water in an overall reaction,

$$
\mathrm{O}_{2}(\mathrm{~g})+2 \mathrm{e}^{-} \rightarrow 2 \mathrm{O}_{\mathrm{s}}^{-}
$$




$$
\begin{aligned}
& \mathrm{O}_{\mathrm{s}}^{-}+\mathrm{H}_{\mathrm{s}}^{+} \rightarrow \mathrm{OH}_{\mathrm{s}} \\
& \underset{\mathrm{O}}{\mathrm{OH}}+\underset{\mathrm{H}}{\mathrm{H}} \rightarrow \mathrm{H}_{2} \mathrm{O}(\mathrm{g})
\end{aligned}
$$

Colmenares [COLMENARES-1984] explains that the reactants in the oxidation of uranium can be described by chemisorption and dissociation of water as follows:

$$
\mathrm{H}_{2} \mathrm{O}_{\mathrm{s}}+\mathrm{O}^{2-}(l, i) \rightarrow \mathrm{OH}^{-}(l, i)+\mathrm{OH}_{\mathrm{s}}^{-}
$$

and

$$
\mathrm{H}_{2} \mathrm{O}_{\mathrm{S}}+\mathrm{O}^{-}(i)+\mathrm{e}^{-} \rightarrow \mathrm{OH}^{-}(i)+\mathrm{OH}_{\mathrm{S}}^{-}
$$

where $l$ and $i$ are lattice-positioned and interstitial-positioned oxygen, respectively, in the $\mathrm{UO}_{2+\mathrm{x}}$ lattice and $\mathrm{O}^{-}$is derived from the catalytic breakdown of surface $\mathrm{OH}^{-}$. The hydroxyl ions diffuse through the lattice in an interstitial mechanism and are responsible for the redox reactions with $\mathrm{U}^{4+}$ to produce the oxide much like in Baker's model:

$$
2 \mathrm{OH}^{-}+\mathrm{U}^{4+} \rightarrow \mathrm{UO}_{2}+2 \mathrm{H}^{+}
$$

The hydrogen is free to diffuse through the oxide, combine with another proton, and produce $\mathrm{H}_{2}$ gas. This mechanism can explain the low activation energy for metallic uranium oxidation because of the relative ease with which $\mathrm{OH}^{-}$and $\mathrm{O}^{-}$can diffuse through a fluorite $\mathrm{UO}_{2}$ latticetype. Also, inhibition of corrosion by the presence of $\mathrm{O}_{2}$ can be explained by its occupation of sites normally utilized by $\mathrm{H}_{2} \mathrm{O}$ to produce hydroxyl ions.

McGillivray et al. [MCGILLIVRAY-1994] used secondary ion mass spectrometry (SIMS) and argues that the uranium oxidation rate can be explained via a Langmuir-type model above $\sim 150{ }^{\circ} \mathrm{C}$ :

$$
R_{U}=\frac{k_{1} P_{\mathrm{H}_{2} \mathrm{O}}}{1+k_{2} P_{\mathrm{H}_{2} \mathrm{O}}}+D
$$

where $k_{1}$ and $k_{2}$ are the rate constants related to the sorption and desorption, $P_{\mathrm{H}_{2} \mathrm{O}}$ is the vapor pressure of water, and $D$ is the dry air oxidation rate. This expression predicts a plateau in the oxidation rate as $P_{\mathrm{H}_{2} \mathrm{O}}$ is increased $\left(R_{U}=k_{1} / k_{2}+D\right.$ as $\left.P_{\mathrm{H}_{2} \mathrm{O}} \rightarrow \infty\right)$ and is only applicable to relative humidity below $90 \%$. Oxygen occupies available sites on the $\mathrm{UO}_{2}$ lattice and contributes to the oxidation of uranium by introducing $\mathrm{O}^{2-}$ species, which diffuse more slowly than water-derived hydroxy species (identical to dry oxidation of uranium). Hydrogen bonding allows water to adsorb on top of the chemisorbed $\mathrm{O}_{2}$ layer and continue to react with the surface, albeit at a lower rate. So, both $\mathrm{H}_{2} \mathrm{O}$ vapor and $\mathrm{O}_{2}$ are believed to contribute reacting species so that the rate is $\sim 75 \%$ from $\mathrm{H}_{2} \mathrm{O}$-contributing species and $\sim 25 \%$ from $\mathrm{O}_{2}$-contributing species at $100{ }^{\circ} \mathrm{C}$ in moist air. 
Haschke [HASCHKE-1998] recently suggested that the reaction proceeds via the following mechanism by which oxygen is separated from water:

$$
\begin{aligned}
& x \mathrm{H}_{2} \mathrm{O}(\mathrm{g}) \rightarrow x \mathrm{H}_{2} \mathrm{O}_{\mathrm{s}} \\
& \mathrm{U}(\mathrm{s})+x \mathrm{H}_{2} \mathrm{O}_{\mathrm{s}} \rightarrow \mathrm{UO}_{\mathrm{x}}(\mathrm{s})+2 x \mathrm{H}_{\mathrm{s}} \\
& \frac{x}{2} \mathrm{O}_{2}(\mathrm{~g}) \rightarrow \frac{x}{2} \mathrm{O}_{2, \mathrm{~s}} \rightarrow x \mathrm{O}_{\mathrm{s}} \\
& 2 x \mathrm{H}_{\mathrm{s}}+x \mathrm{O}_{\mathrm{s}} \rightarrow x \mathrm{H}_{2} \mathrm{O}_{\mathrm{s}} \rightarrow x \mathrm{H}_{2} \mathrm{O}(\mathrm{g})
\end{aligned}
$$

where (ads) indicates species adsorbed to the $\mathrm{UO}_{2}$ lattice. Baker and Haschke mechanisms are consistent with isotope-labeled ${ }^{18} \mathrm{O}$ experiments of Baker et al. [BAKER-1966] for a net reaction of

$$
\mathrm{U}(\mathrm{s})+x \mathrm{H}_{2} \mathrm{O}(\mathrm{g})+\frac{x_{18}}{2} \mathrm{O}_{2}(\mathrm{~g}) \rightarrow \mathrm{UO}_{x}+x \mathrm{H}_{2}{ }^{18} \mathrm{O}(\mathrm{g})
$$

where the ${ }^{18} \mathrm{O}$ is traced. Weirick [WEIRICK-1984] did not substantiate the isotopic studies of Baker et al. [BAKER-1966], but Haschke [HASCHKE-1998] dismissed Weirick's results because of a number of inconsistencies. In support of Weirick, McGillivray's mechanisms allows for isotopically rich and normal oxygen to appear in the oxide simply because both gases, $\mathrm{O}_{2}$ and $\mathrm{H}_{2} \mathrm{O}$, impart reacting species $\left(\mathrm{O}^{2-}\right.$ and $\mathrm{OH}^{-}$, respectively). It is clear that more careful work is needed in the use of isotopically labeled $\mathrm{H}_{2} \mathrm{O}$ and $\mathrm{O}_{2}$ before a conclusion can be drawn.

Above $90 \% \mathrm{RH}$, the reaction rate again changes, indicating a change in reaction mechanism. Saturated vapor conditions yield equivalent corrosion rates to water immersion tests [BAKER-1966] when no $\mathrm{O}_{2}$ is present in either system. Increasing humidity above 50-70\% (greatly depending on test sample) will produce a maximum in oxidation rate that can then lead to a reduced rate at humidity levels approaching saturation. Baker et al. [BAKER-1966] explained that this could be due to water invasion into microfissures in the oxide layer that suppress the release of $\mathrm{H}_{2}$. The buildup of $\mathrm{H}_{2}$ in the microfissures simultaneously slows water diffusion to the oxide-metal interface that reduces the corrosion rate at levels approaching saturation. If oxygen is present, the rate increases markedly near water saturation and may be explained by surface pitting and the exclusion of $\mathrm{O}_{2}$ from surface sites by the mass action of water, both phenomena increasing the availability of water to react with the metal. Hydrogen is produced at a linear rate in accordance with the mechanism of Eq. 2 with slightly less than stoichiometric $\mathrm{H}_{2}(>85 \%)$. The deficit is owed to $\mathrm{UH}_{3}$ production that reduces $\mathrm{H}_{2}$ generation by a factor of eight ${ }^{1}$ via

$$
4 \mathrm{U}(\mathrm{s})+4 \mathrm{H}_{2} \mathrm{O} \rightarrow 2 \mathrm{UO}_{2}+\mathrm{H}_{2}+2 \mathrm{UH}_{3}
$$

\footnotetext{
${ }^{1}$ Compare to Eq. 2 where $2 \mathrm{H}_{2}$ are produced for every $\mathrm{U}$ oxidized.
} 
Typical rates determined for the corrosion of uranium metal are provided in Table 1 for reference.

Table 1. Reaction Rates for Uranium Oxidation under Various Conditions

\begin{tabular}{lcccc}
\hline \multicolumn{1}{c}{ Author } & $P_{O_{2}}$ & RH $(\%)$ & $\mathrm{T}$ & Rate $\left(\mathrm{mg} / \mathrm{cm}^{2} / \mathrm{h}\right)$ \\
\hline ORMAN-1964 & 0 & 100 & 100 & 4.75 \\
ORMAN-1964 & 0 & immersed & 100 & 4.2 \\
WABER-1952 & 0 & immersed & 90 & 1.01 \\
RITCHIE-1981 & 0 & 100 & 90 & 1.54 \\
WABER-1952 & air & immersed & 80 & 0.57 \\
RITCHIE-1981 & air & 100 & 90 & 0.09 \\
\hline
\end{tabular}

In the case of irradiated fuels, it has been shown that the corrosion rate was not enhanced due to radiolysis products as demonstrated during gamma irradiation experiments [BAKER1966]. Instead, the small increase in reaction rate with irradiated fuel results from a decrease in fuel density and increase in swelling.

\section{$\underline{\text { Objectives }}$}

The objectives of the batch tests with metallic uranium fuel was to determine the effects of an anoxic environment on the corrosion of metallic uranium fuels by assessing the paragenesis of alteration products, disposition of fission products and actinides, colloid occurrence and properties, and solution chemistry. Following this anoxic testing period, the fuel was exposed to oxic conditions and the immediate change in solution chemistry and paragenesis assessed.

\section{EXPERIMENTAL AND TECHNICAL APPROACH}

The experimental procedure is detailed in the Standard Operating Procedure - Procedure for Batch Testing of Metallic Uranium Fuel Under Saturated Water and Variable-Oxygen Atmosphere (WMRD-SOP-061, Rev. 0) but will be paraphrased here. Scientific Notebook \#1763 contains all data or references to data generated under this program.

All tests were run in 22-mL stainless steel Parr vessels. The Parr vessel caps were modified with welded quick-disconnect male fittings to accept a gas pressure gauge. Water from the $\mathrm{J}-13$ well was reacted at $90{ }^{\circ} \mathrm{C}$ for 21 days with crushed core samples of Topopah Spring tuff. $\mathrm{J}-13$ well water prepared in this manner is called EJ-13 and is characterized by a higher silicon and sodium content than $\mathrm{J}-13$ water. Ultrapure nitric acid (16 $\underline{\mathrm{M}})$ was used to acidify samples prior to analysis ( $\sim 5 \mu \mathrm{L}$ per $400 \mu \mathrm{L}$ sample). EJ-13 (MG Bottle \#3 or TSR\#MK09) was purged with humid $\mathrm{N}_{2}$ for 1.5 days before initial use and stored in the anoxic atmosphere thereafter. All components were purged with Ar or $\mathrm{N}_{2}$ before use. By measuring the dissolved oxygen, it was observed that sparging the solution with $\mathrm{N}_{2}$ or $\mathrm{Ar}$ gas reduced the dissolved oxygen concentration within about one minute to below the detection limits of the probe $(0.04 \mathrm{ppm})$. By providing a blanket of inert gas (as opposed to sparging the solution by submerging the gas line in the solution) the $\mathrm{O}_{2}$ can be reduced to $<0.04 \mathrm{ppm}$ in about $20 \mathrm{~min}$. Water from MG Bottle \#3 
was used for the initial experiment (test UUBT1) and stored in the portable glovebox (atmospheric $\mathrm{O}_{2}$ was 1.9-2.3\%). Water from TSR \#MK09 was stored in the Plexiglas containment box (atmospheric $\mathrm{O}_{2}<10 \mathrm{ppm}$ ). See below for descriptions of the glovebox and containment box configuration. The EJ-13 batches were analyzed regularly and typical values are shown in Table 2.

Table 2. Elemental Concentration for Deaerated EJ-13 Water Used in the Mock Tests

\begin{tabular}{ccc|ccc}
\hline Element & $\begin{array}{c}\text { Conc., } \\
\mathrm{ng} / \mathrm{g}\end{array}$ & $\begin{array}{c}\text { Standard } \\
\text { Deviation }\end{array}$ & Element & $\begin{array}{c}\text { Conc., } \\
\mathrm{ng} / \mathrm{g}\end{array}$ & $\begin{array}{c}\text { Standard } \\
\text { Deviation }\end{array}$ \\
\hline $\mathrm{Li}$ & 70 & 70 & $\mathrm{Fe}$ & 800 & 400 \\
$\mathrm{~B}$ & 80 & 300 & $\mathrm{Zr}$ & 2 & 1 \\
$\mathrm{Na}$ & 46000 & 6000 & $\mathrm{Au}$ & $<2.6$ & 0.8 \\
$\mathrm{Mg}$ & 300 & 100 & $\mathrm{U}$ & $<1.8$ & 0.5 \\
$\mathrm{Al}$ & 500 & 300 & $\mathrm{Ni}$ & 9 & 6 \\
$\mathrm{Si}$ & 35000 & 3000 & $\mathrm{Sr}$ & 39 & 2 \\
$\mathrm{P}$ & 380 & 70 & $\mathrm{Cs}$ & 1.8 & 0.3 \\
$\mathrm{~K}$ & 10000 & 2000 & $\mathrm{~Np}-237$ & $<0.1$ & $<0.1$ \\
$\mathrm{Ca}$ & 8400 & 700 & $\mathrm{U}-238$ & 0.6 & 0.6 \\
$\mathrm{Cr}$ & $<45$ & 20 & $\mathrm{Pu}-239$ & $<0.2$ & $<0.2$ \\
$\mathrm{Mn}$ & $<8$ & 2 & $\mathrm{Am}-241$ & $<0.1$ & $<0.1$ \\
\hline
\end{tabular}

All activities were done in the controlled atmosphere except where noted and during the oxic testing periods (see below). The fuel was cut from unirradiated N-Reactor fuel elements into small wedges with the cladding removed. The fuel was polished with 600 grit $\mathrm{SiC}$ and ultrasonically rinsed in deionized water for $2-3 \mathrm{~min}$. The test was initiated by placing the fuel piece $(\sim 100 \mathrm{mg})$ at the bottom of the Parr vessel or on a gold screen $(11-\mu \mathrm{m}$ nominal opening) held in a steel lifting bail. The EJ-13 was added to the vessel $(10-16 \mathrm{~mL})$, the vessel was sealed to $140 \mathrm{ft}-\mathrm{lb}$ torque with steel enclosures and a copper gasket, and placed in the heating block at $90^{\circ} \mathrm{C}$ until it was sampled. A test vessel were sampled by cooling the vessel to room temperature using dry ice, transferred out of the glovebox (for UUBT1) and weighed, and the cap was loosened but not fully opened (test UUBT2 was located outside the containment box when sealed). The vessel was transferred back into the glovebox or containment box, the cap was removed, pictures were taken, and liquid samples were withdrawn for analysis. Four hundred microliters each was withdrawn for $\mathrm{pH}$ measurement, dissolved ion concentration (by passing through a 30,000 MW filter), colloid + dissolved ion concentration ${ }^{2}$ (by passing through a $0.45 \mu \mathrm{m}$ filter), and the colloid size distribution. Tests were restarted, following a sampling, by resealing the vessel and replacing it in the heating block or replenishing the EJ-13 volume in the vessel before sealing.

Pictures were captured by a digital camera, alone, or attached to a Navitar (12X) zoom lens optical microscope. Field of view was measured with a mechanical ruler. Solutions were

\footnotetext{
${ }^{2}$ By subtracting the dissolved ion filtrate concentration from this value the uranium concentration associated with
} colloids is determined. 
submitted to in-house inductively coupled plasma-mass spectrometry (Fisons VG PlasmaQuadII+ series) as described elsewhere [WOLF-1998]. The Eh was measured with a ORION 420A combination $\mathrm{pH} / \mathrm{Eh}$ instrument and $\mathrm{Pt}-\mathrm{Ag} / \mathrm{AgCl}$ electrode. Solution $\mathrm{pH}$ was measured with a Sentron Instruments $2001 \mathrm{pH}$ meter. Electron microscopy was performed by passing $5 \mu \mathrm{L}$ of solution through a holey carbon grid and analyzing the grid using a Hitachi S3000N scanning electron microscope (SEM) coupled to a NORAN energy dispersive X-ray spectroscope (EDS), and a JEOL 2000 FXII transmission electron microscope operating at $200 \mathrm{kV}$. Dissolved oxygen was measured using a Microelectrodes, Inc. Model MI-730 $\mathrm{O}_{2}$ selective electrode and OM-4 oxygen meter calibrated to deionized water equilibrated with ambient air. The dissolved oxygen was computed based on the instrument readout according to Eq. 20:

$$
\mathrm{CO}_{2}[\mathrm{ppm}]=\frac{a}{22.414} \frac{(760-p)}{760} \frac{\mathrm{R}}{100} \times 32 \times 1000
$$

where $\mathrm{R}$ is the universal gas constant, $a$ is a temperature-dependent constant $\left(0.03044\right.$ at $\left.21{ }^{\circ} \mathrm{C}\right)$ and $p$ is the pressure in $\mathrm{mm}$ of $\mathrm{Hg}\left(18.65\right.$ at $\left.21{ }^{\circ} \mathrm{C}\right)$. Solutions in equilibrium with the atmosphere show a reading of 20.9 or $8.86 \mathrm{ppm}$. The detection limit for this instrument is 0.04 ppm dissolved oxygen or $0.1 \% \mathrm{O}_{2}$ in gas. The containment air was monitored using a Teledyne Analytical Instruments AO 316-H oxygen analyzer calibrated to ambient air.

Colloid size distribution was estimated using photon correlation spectrometry or dynamic light scattering [Malvern PCS4700C analyzer and Uniphase Ar ion laser (Model 2213-75CL)] checked against NIST polystyrene standards (SRM 1963 and SRM 1691, 100 and $300 \mathrm{~nm}$ nominal diameters, respectively). Colloid samples were withdrawn from the test vessels into cylindrical glass vials and capped. Samples were stored in the reservoir of the containment box at room temperature and purged continuously with $\mathrm{N}_{2}$.

Before exposing the test vessels to an oxic environment, a small amount of oxidized fuel slurry powder $(<5 \mathrm{mg})$ was removed by pipette for XRD analyses. This sample was stored in the containment box until removed for analysis. The estimated exposure time of fuel powder to ambient air was $<2 \mathrm{~h}$, for sample preparation and transfer, and $24 \mathrm{~h}$ for analysis. This time is not considered sufficient to cause further oxidation of the fuel powder. The sample was prepared by centrifuging the wet powder and withdrawing the supernatant EJ-13. Ethanol was added to the vial, and the resultant suspension withdrawn by pipette onto a zero-background single crystal silicon XRD planchet. The ethanol was driven off by placing the planchet in an oven at $90{ }^{\circ} \mathrm{C}$ for five minutes. The ethanol provided a suitable fixing agent for this type of powder sample. The solid products were identified using a Rigaku MiniFlex X-ray diffractometer, and the results compared to powder diffraction files from the International Centre for Diffraction Data. Standard silicon powder was analyzed subsequent to the sample analysis to check calibration and was in full agreement. (See Appendix A for the raw data and diffractometer scan parameters.)

An anoxic environment was created for test sampling and restarts. It was designed to provide adequate radiation shielding for eventual tests with irradiated metallic uranium fuels. The initial experimental setup for the anoxic test conditions was created in a portable glovebox purged with $\mathrm{Ar}$ or $\mathrm{N}_{2}$ (see Fig. 2). The glovebox was modified to include a temperature- 
controlled aluminum block capable of single-temperature control of four to six vessels (22- or 44-mL Parr vessels). A Parr vessel filled with sand was connected to the external power supply via two thermocouples to control the block temperature and for over-temperature control. The glovebox was purged with dry Ar daily, but not continuously. Samples and supplies were transferred in and out of the glovebox in a manner minimizing oxygen invasion. Equipment was first placed in the transfer port with the inner door sealed. The transfer port was evacuated to -15 psig, filled with dry Ar to $-5-0$ psig, evacuated to $-15 \mathrm{psig}$, and filled again with dry Ar to 0 psig. The contents were then transferred through the inner port to the glovebox. Transfers outside the glovebox were completed by opening the inner port (the transfer port was filled with Ar from the previous transfer), placing the contents into the transfer port, and closing the inner port. The outer port could then be opened to remove the contents.

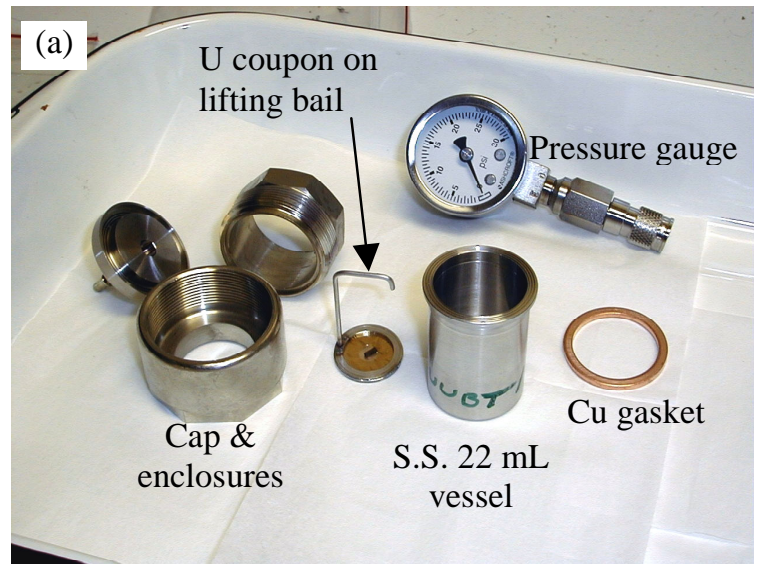

Fig. 2. Experimental Test Components:

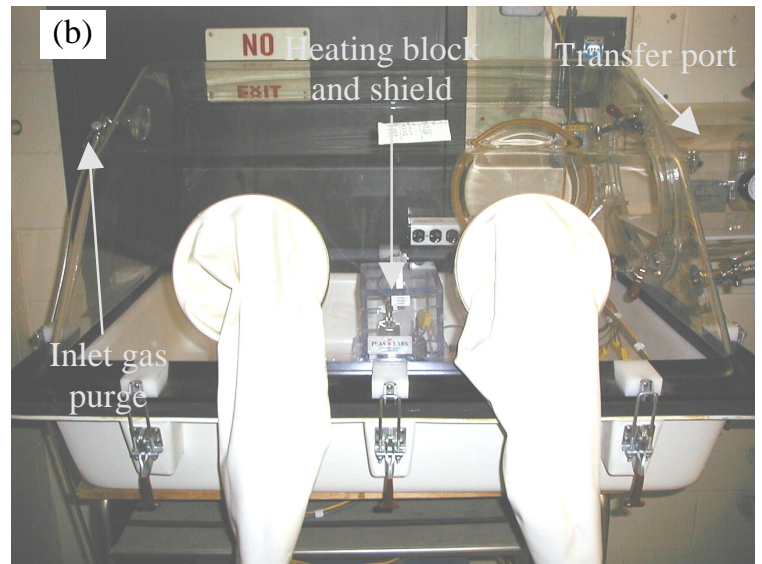

(a) Batch Test Vessel and Components and (b) Portable Glovebox Used in Anoxic Uranium Metal Batch Tests

It was recognized during the mock test UUBT1 that there were several deficiencies in the experimental setup. First, the oxygen concentration in the glovebox was consistently 1.8-2.0 $\mathrm{mol} \% \mathrm{O}_{2}$ at $21^{\circ} \mathrm{C}$. The dissolved oxygen for a solution in equilibrium with the glovebox gas at this $\mathrm{O}_{2}$ level is $0.76-0.85 \mathrm{ppm}$. The dissolved oxygen that was measured in the EJ-13 stock bottle (MG Bottle \#3) was $2.3 \%$ or $0.98 \mathrm{ppm}$. These levels were not considered sufficiently low to eliminate the participation of oxygen in the corrosion of the fuel.

Before the start of the second mock test UUBT2, the experimental setup was modified to address the aforementioned concerns. A Plexiglas containment box was fabricated for operation within a standard fume hood. As shown in Fig. 3, the containment box contained an air pump for continuous sampling of the $\mathrm{O}_{2}$ levels in the box, a working platform, cylindrical access shaft in the top (not shown) for a digital microscope, and storage unit below. A trap door in the floor of the working platform allowed access to vials in the storage unit. The entire containment box was purged constantly with $\mathrm{N}_{2}$ that had been filtered to remove oils and moisture. The joints in the Plexiglas were sealed with RTV except for the top that was rendered tight by placing a rubber gasket between it and the tops of the six walls and sealing with screws. For this setup, the containment box $\mathrm{O}_{2}$ levels were monitored using the Teledyne $\mathrm{O}_{2}$ Analyzer because the $\mathrm{O}_{2}$ levels would be below the detection limit of the $\mathrm{O}_{2}$ selective electrode. 


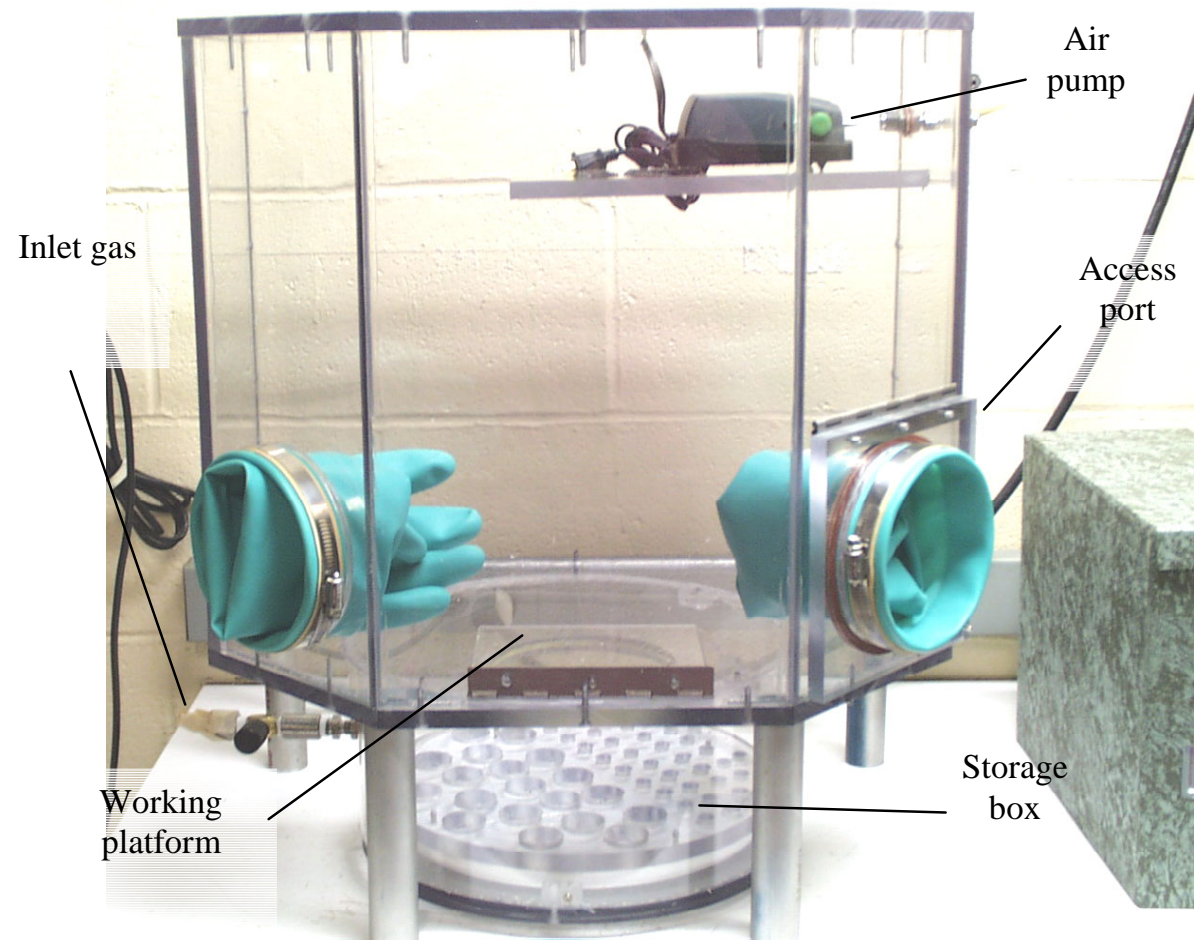

Fig. 3. Controlled Atmosphere Containment Box Developed for Metallic Uranium Batch Testing Program

The $\mathrm{O}_{2}$ levels were measured in the containment box to simulate real preparation and sampling conditions. The box could maintain $<50 \mathrm{ppm} \mathrm{O}_{2}$ in $\mathrm{N}_{2}$ during active sampling and $<10$ ppm when the box was left undisturbed. Inserting items into the containment box required entrance through the gloveport, which introduced atmospheric oxygen into the box. Figure 4 contains plots of the oxygen levels in the box after opening the gloveport at various $\mathrm{N}_{2}$ inlet purge pressures. As can be seen, the containment box is purged quickly: only $20 \mathrm{~min}$ is required to reach <10 ppm from initial levels of 11,000 ppm. 


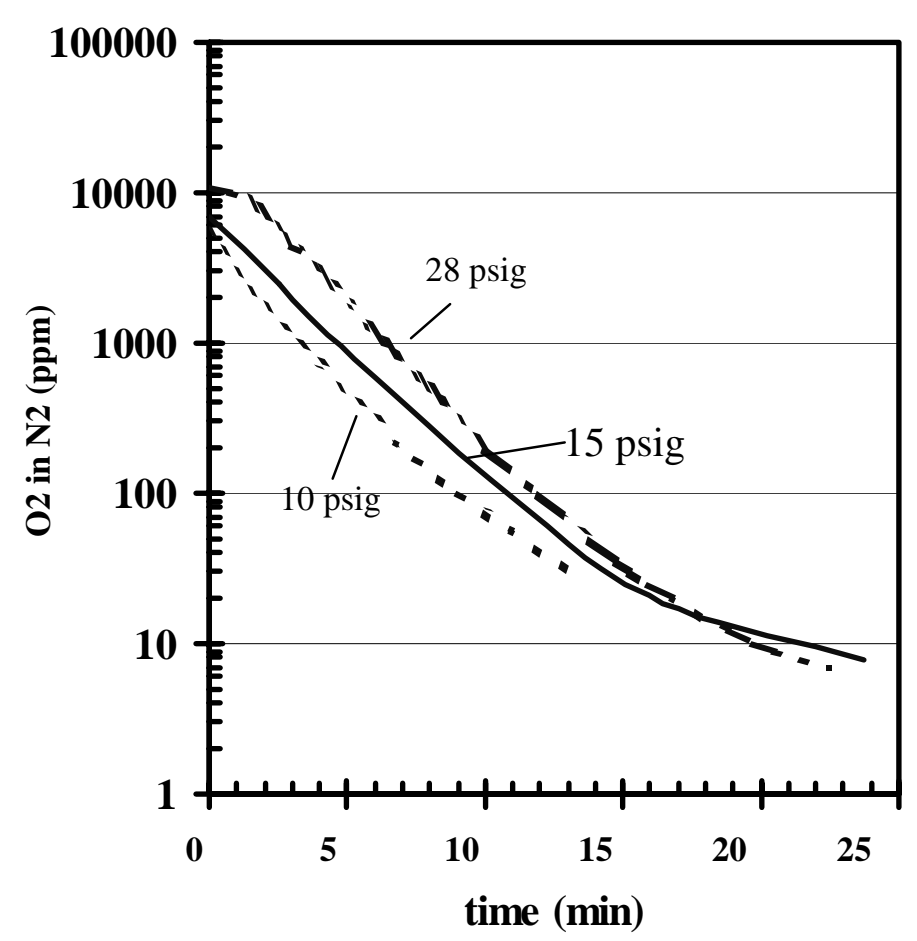

Fig. 4. Measured $\mathrm{O}_{2}$ Concentrations in the Controlled Atmosphere Containment Box as a Function of Time Following Opening of the Gloveport. $\mathrm{N}_{2}$ purge pressure was 10,15 , and 28 psig

\section{RESULTS}

The mock uranium batch test program schedule is highlighted below.

\begin{tabular}{ll}
\hline Safety review & Approved 9/00 \\
Portable glovebox modified & Completed 9/00 \\
Draft Test Plan Approval & $9 / 00$ \\
UUBT1* Test Start: & $9 / 22 / 00$ \\
UUBT1 Sampling: & $9 / 28 / 00,10 / 10 / 00,10 / 24 / 00,11 / 6 / 01$ \\
UUBB1 $^{\dagger}$ Blank Test Start: & $11 / 00$ \\
Test Plan & Approved $1 / 30 / 01$ \\
Standard Operating Procedure & Approved 2/12/01 \\
UUBT2 $2^{\ddagger}$ Test Start: & $1 / 25 / 01$ \\
UUBT2 Test Sampling: & $1 / 31 / 01,2 / 22 / 01,3 / 20 / 01,5 / 11 / 01,6 / 11 / 01$ \\
UUBB1 Test Start: & $2 / 22 / 01$ \\
UUBB1 Test Sampling & $6 / 18 / 01$ \\
\hline
\end{tabular}

*Unirradiated Uranium Batch Test sample \#1

${ }^{\dagger}$ Unirradiated Uranium Blank Batch test \#1

Unirradiated Uranium Batch Test sample \#2 
More details for the three tests UUBT1, UUBT2, and UUBB1 are given in Table 3 and the following sections will detail the individual tests, in turn. In the final section, a summary will be provided. The starting $\mathrm{pH}$ of the deaerated EJ-13 was 8.0-8.6, similar to the aerated values. For UUBT1 no EJ-13 was added to the test vessel at samplings to replenish any lost liquid. The liquid contents decreased from $15.99 \mathrm{~g}$ to $9.85 \mathrm{~g}$ at test termination due to aliquots removed for sampling and vapor lost at the lid/base closure seal. Tests UUBT2 and UUBB1 were replenished with EJ-13 to compensate for lost volume. For UUBT1, the $\mathrm{pH}$ of the reacted solution was slightly acidic at 5.8-5.9 while the blank pH was 7.1. The Eh of the EJ-13 before the test start was $240 \mathrm{mV}$ (vs. Calomel) and was not significantly different than aerated EJ-13. The Eh was monitored periodically during test UUBT2 and was consistent with UUBT1 values.

\section{A. $\quad \underline{\text { UUT1 }}$}

\section{Physical Observations}

Test UUBT1 was first sampled after six days. The fuel was intact and black, but a small volume of black $\mathrm{UO}_{2}$ fines was noted on the gold screen of the lifting bail. After 17 days, the proportion of fines increased and, now, mixed brown and black fines could be discerned. The fuel surface had browned noticeably but was not noticeably reduced in size. The brown color of $\mathrm{UO}_{2}$ is consistent with near stoichiometric $\mathrm{UO}_{2}(\mathrm{x} \rightarrow 0), \mathrm{H}_{2}$ presence, and reducing conditions, although there was no evidence of appreciable gas generation until about 40 days into the test.

After 32 days, the population of brown colored fines immediately surrounding the fuel had increased. The fuel surface was brown with hints of black. Representative morphologies for the uranium fines are shown in Fig. 5. The fines appeared to be exfoliated sheets of the oxidized metal $<1 \mu \mathrm{m}$ thick or flaky agglomerations that were typically $<30 \mu \mathrm{m}$ in length. When the vessel was opened after 45 day, the fuel was $~ 80-90 \%$ disaggregated into brown fines. 


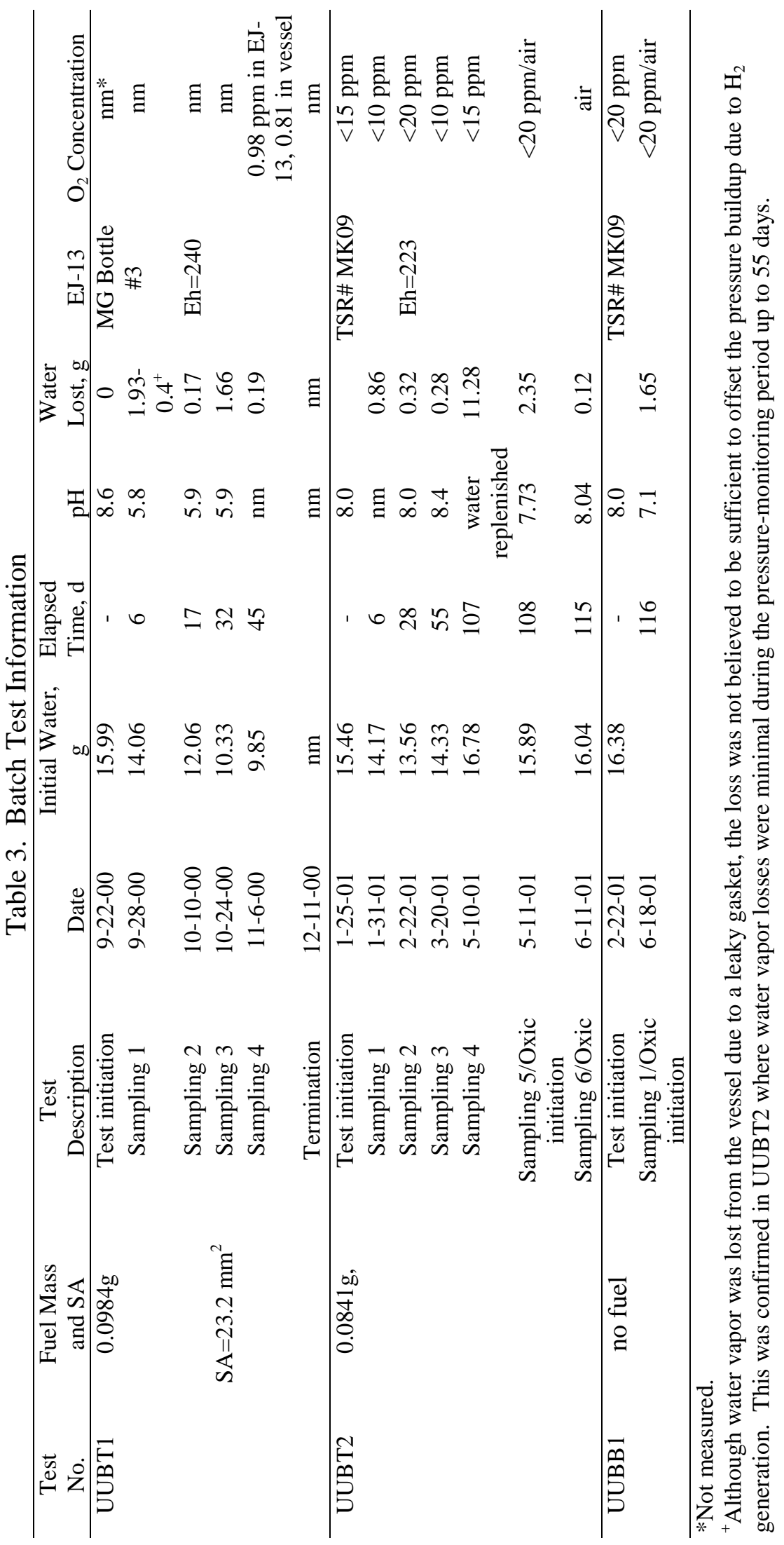



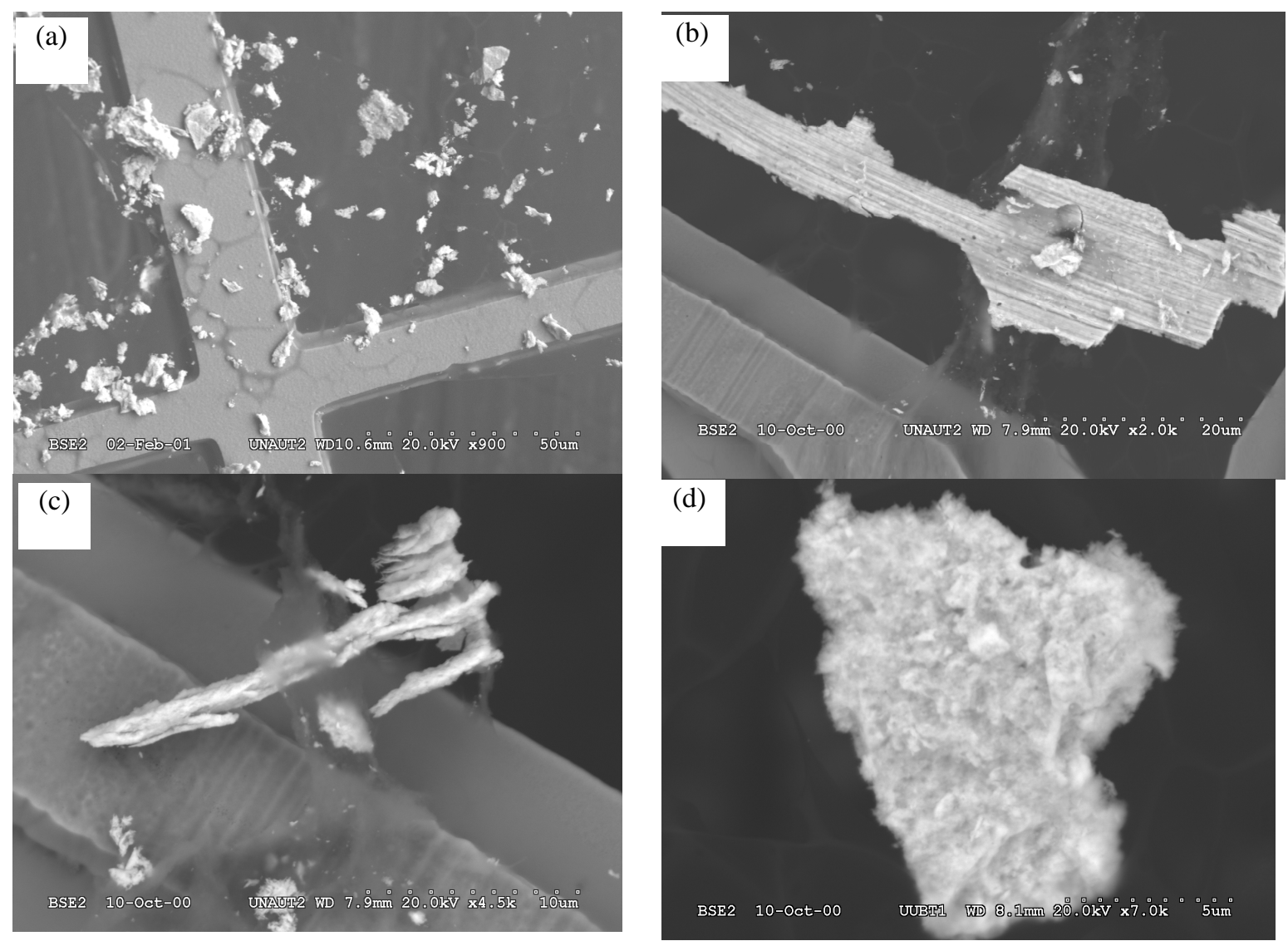

Fig. 5. Spallation Products from the Corrosion of Metallic Uranium Fuel after 45 days. (a) An expanded view. A closer view is provided of the exfoliated sheets (b, c) and the flaky surface of some fines $(\mathrm{d})$. The test vessels were exposed to containment air with $2 \% \mathrm{O}_{2}$.

\section{Gas Generation}

Between sampling at 32 and at 45 days into the test, 2-3 psig of gas was generated in the vessel. The vessel was resealed after 45 days and the gas pressure rose linearly until about 66 days as shown in Fig. 6. Assuming the mechanism shown in Eq. 2 with $n=0$, the calculated uranium corrosion rate is $1.9 \mathrm{mg} \mathrm{U} / \mathrm{d}$ for the linear period from 45-66 days. During this period the amount of fuel oxidized corresponded to $1.9 \mathrm{mg} / \mathrm{d} \mathrm{x} 22 \mathrm{~d}=41.8 \mathrm{mg}$ or $42 \%$ of the fuel. If $\mathrm{H}_{2}$ production were the preponderant mechanism, then approximately 52 days would be required for complete oxidation of the fuel at this rate, ignoring other effects (e.g., surface area, ionic transport). From this exercise, it is quite apparent that the fuel corrosion followed at least two mechanisms. The corrosion mechanism that dominated the initial period produced no measurable gas release for a period lasting almost one month. These results are completely contrary to those of Baker et al., as one would expect a linear rate of $\mathrm{H}_{2}$ production in accordance with Eq. 2. Afterward, a net gas release was observed signaling a second mechanism and implying the dominance of Eq. 2. It also appears that since gas production began before a sampling (when the $\mathrm{O}_{2}$ levels in the vessel would be most depleted) 
and continued after the sampling, once the second period had begun it continued despite the solution being partly equilibrated with air containing $2 \% \mathrm{O}_{2}$. This behavior suggests that the onset of the second period is independent of the oxygen concentration in water and must therefore be a function of the altered matrix of the fuel. In other words, the fuel condition by about the $45^{\text {th }}$ day had become such that hydrogen gas was not being suppressed, since its production is expected based on undersaturated tests, as described in the Introduction.

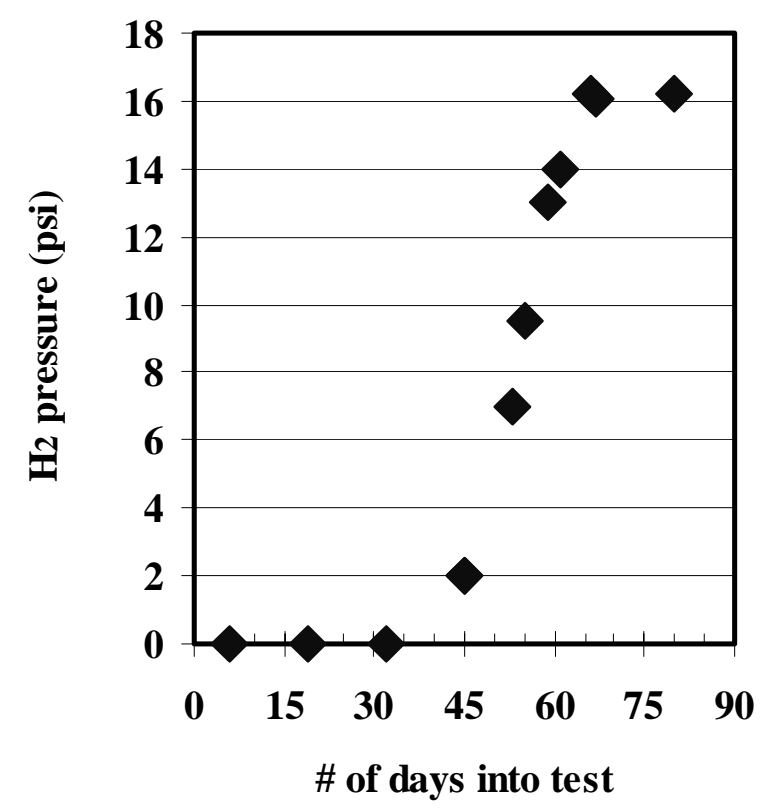

Fig. 6. The Inferred $\mathrm{H}_{2}$ Gas Produced during the Corrosion of $98.4 \mathrm{mg}$ of Uranium Metal in Test UUBT1

\section{Colloids}

Colloids were not present in detectable concentrations until the sampling at day 17. Table 4 provides supporting data. By day 6 , the scattering intensity of the solution ${ }^{3}$ was comparable to that of deaerated EJ-13 water $\left(\sim 6-10 \times 10^{3}\right.$ counts/sec). By day 32 the dissolved uranium concentration had risen from $500 \mathrm{ppb}$ at days 6 and 17 to $2660 \mathrm{ppb}$ and a colloid population had formed to detectable concentrations producing scattering intensities ten times background. Analysis by ICP-MS could not confirm the existence of colloidal uranium by day 32 , within the limit of the calculation error, nor could other elements typically observed in fuel environmental colloids be determined to reasonable accuracy (see Appendix A for compilation of ICP-MS data). Of course, this does not mean that the colloids detected by light scattering could not be composed of uranium, aluminum, or silicon, or other elements but that the subtraction technique used to determine colloid concentration is insufficiently accurate. In fact, as shown in the following section, the colloids borne from uranium corrosion are

\footnotetext{
${ }^{3}$ The light scattering intensity is a measure of the number of colloids in the sample assuming colloids of monomodal size are generated.
} 
composed of many elements not apparent from solution elemental analysis. Size distribution data could not be generated by light scattering analysis due to the disperse nature of the sample indicated by the polydispersity index from light scattering analysis. The polydispersity for UUBT1 samples was typically $>0.5 .^{4}$

Table 4. Light Scattering Intensity for Samples Withdrawn During Test UUBT1

\begin{tabular}{cccc}
\hline Sample & Date of Analysis & $\begin{array}{c}\text { Light Scattering } \\
\text { Intensity }\left(\mathrm{x} 10^{3} \mathrm{cps}\right)\end{array}$ & $\begin{array}{c}\text { Laser Power } \\
(\mathrm{mW})\end{array}$ \\
\hline EJ-13 & periodically & $6-10$ & 3 \\
day 6 & $10-11-00$ & 60 & 50 \\
day 17 & $6-26-01$ & 22 & 3 \\
day 32 & $11-6-00$ & 100 & 3 \\
day 32 & $6-26-01$ & $<10$ & 3 \\
\hline
\end{tabular}

The stability of the colloids was examined by periodically analyzing stored samples. Light scattering intensities also are shown in Table 4 for the limited data set. Though colloids collected at day 17 (10-10-00) were analyzed $81 / 2$ months later (6-26-01) and were readily detected, they were not detected in the day 32 sample analyzed nine months after collection. At this point, it is unclear whether the colloids are stable for transport or sensitive to slight changes in solution that may occur during storage or subsurface transport. Colloid stability is examined in more detail in the next section describing results from UUBT2.

\section{B. $\quad \underline{\text { UUBT2 }}$}

\section{Physical Observations}

Because the $\mathrm{O}_{2}$ concentration maintained in the glovebox used for Test UUBT1 was not sufficiently low $\left(1.8-2.0 \mathrm{~mol} \% \mathrm{O}_{2}\right)$, a second test, UUBT2, was run in a containment box with significantly lower $\mathrm{O}_{2}\left(<50 \mathrm{ppm} \mathrm{O}_{2}\right.$ in atmosphere). As in test UUBT1, the fuel in UUBT2 produced spalled products but remained in good condition with sharp edges and corners after six days. Up to day 55, the original fuel piece was distinguishable but the vessel bottom was dominated by $\mathrm{UO}_{2}$ fines. After 108 days the fuel appeared to be completely converted to the $\mathrm{UO}_{2}$ fines. The fines appeared to be similar in morphology to those examined from UUBT1 at test termination when less flaky particulate was abundant. Example micrographs are provided in Figs. 7-8. Baker et al. [BAKER-1966] reported that fines created under oxygen-starved conditions had a BET surface area of $30 \mathrm{~m}^{2} / \mathrm{g}$.

\footnotetext{
${ }^{4} \mathrm{~A}$ polydispersity index of $<0.3$ is ideal for light scattering although values as high as 0.5 have been amenable under special circumstances.
} 


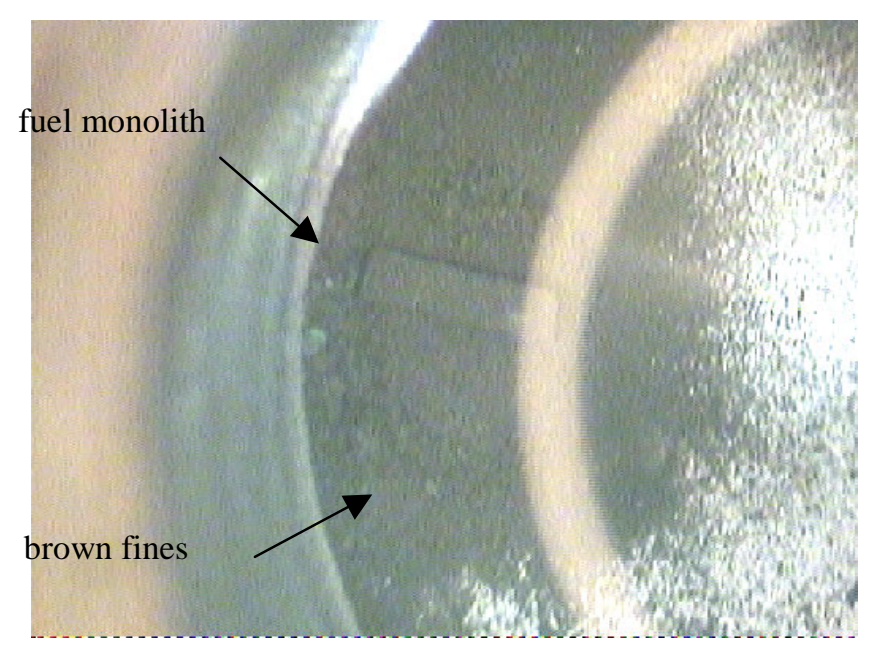

Fig. 7. Optical Microscopic Image of the Partially Oxidized Fuel and Spalled Products Found at the Bottom of the Test Vessel (Test UUBT2 at 28 Days, Field of View $=14.7 \mathrm{~mm}$ )

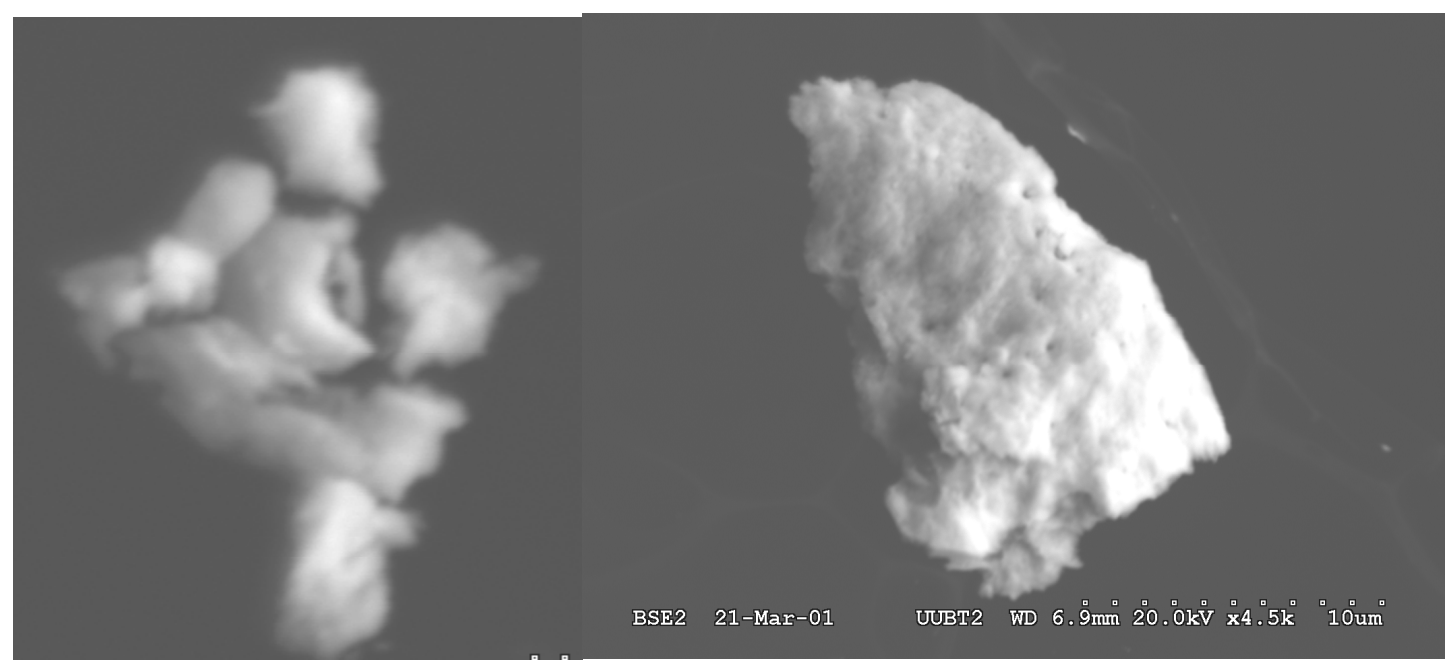

Fig. 8. SEM Images of Suspended Uranium Oxides Found in Test UUBT2 at 55 Days

A portion of the powder was collected for XRD analysis. The diffraction peaks for the sample collected after 108 days of reaction are shown in Table 5. 
Table 5. Diffraction Peaks Identified for Oxidized Uranium Metal

\begin{tabular}{ccc}
\hline $\begin{array}{c}\text { Peak Location } \\
(2 \theta)\end{array}$ & $\begin{array}{c}\text { Relative } \\
\text { Intensity }\end{array}$ & $\begin{array}{c}\text { Full Width Half } \\
\text { Maximum } \\
\left({ }^{\circ}\right)\end{array}$ \\
\hline 12 & 3.3 & 0.12 \\
28.447 & 100 & 1 \\
32.799 & 38 & 1.075 \\
47.365 & 47.1 & 1.319 \\
56.031 & 37.9 & 1.319 \\
58.722 & 8.5 & 1.319 \\
69.011 & 4.8 & 1.825 \\
76.114 & 13.4 & 1.825 \\
78.411 & 8.9 & 1.825 \\
87.926 & 9.8 & 2.04 \\
94.665 & 8.4 & 2.04 \\
$\sim 107$ & 5.9 & $>2$ \\
$\sim 115$ & 17.3 & $>2$ \\
\hline
\end{tabular}

The diffraction pattern is shown in Fig. 9 and reveals remarkably wide peaks, which correspond to very small scattering domains and this will be expounded on shortly. All peaks can be accounted for by uraninite except for that occurring at $2 \theta=12.0^{\circ}$. The location of this peak is consistent with higher oxidation uranyl oxyhydroxides of which schoepite $\left(\mathrm{UO}_{2}\right)_{8} \mathrm{O}_{2}(\mathrm{OH})_{12}\left(\mathrm{H}_{2} \mathrm{O}\right)_{12} \quad\left(2 \theta=12.001^{\circ}\right)$, metaschoepite $\left(\mathrm{UO}_{2}\right)_{8} \mathrm{O}_{2}(\mathrm{OH})_{12}\left(\mathrm{H}_{2} \mathrm{O}\right)_{10}$ $\left(2 \theta=12.041^{\circ}\right)$, and possibly ianthinite $\mathrm{U}^{4+}\left(\mathrm{UO}_{2}\right) \mathrm{O}_{4}(\mathrm{OH})_{6}\left(\mathrm{H}_{2} \mathrm{O}\right)_{9}\left(2 \theta=11.64^{\circ}\right)$ are candidates. It would be very difficult to identify the exact phase that is responsible for the $12.0^{\circ}$ peak since the secondary diffraction peaks of the uranyl minerals coincides with the broad $\mathrm{UO}_{2}$ peaks in this sample making confirmatory identification impossible. However, uranyl species are present. This result may appear to be somewhat surprising since one might expect an anoxic environment to produce $\mathrm{UO}_{2+\mathrm{x}}$ but Haschke reported similar results [HASCHKE-1998] based on XRD where a mixture of $\mathrm{UO}_{2}$ and hydrated $\mathrm{UO}_{3}$ was detected under anoxic corrosion. Also, there is a small systematic shift in the $\mathrm{UO}_{2}$ peak locations to higher $2 \theta$ that translates to a lower unit cell parameter indicative of excess oxygen above stoichiometry. This shift is expected based on Colmenares' review [COLMENARES-1984] on the occurrence of $\mathrm{UO}_{2+\mathrm{x}}$ from the wet oxidation of uranium metal in the absence of oxygen. Quantitative evidence for hyperstoichiometric $\mathrm{UO}_{2+\mathrm{x}}$ is provided by cell refinement which indicated $\mathrm{UO}_{2+\mathrm{x}}$ with a calculated cell parameter ${ }^{5}$ of $5.445 \pm 0.007 \AA$ compared to a value of $5.440 \AA$ for $\mathrm{U}_{4} \mathrm{O}_{9}$ $\left(\mathrm{UO}_{2.25}\right)$ and $5.468 \AA$ for $\mathrm{UO}_{2.03}$ suggesting the spalled product is closer to $\mathrm{UO}_{2.25}$ than $\mathrm{UO}_{2.0}$. This finding is consistent with the presence of the uranyl compounds in the diffraction pattern and appears to agree with Haschke [HASCHKE-1998]. At the same time it differs from the results of Baker [BAKER-1966] who found the product oxide to be $\mathrm{UO}_{2.06 \pm 0.02}$ when oxygen was absent in the reaction. When the product oxide was subsequently exposed to oxygen at elevated temperatures the oxide $\mathrm{UO}_{2.2 \pm 0.1}$ was produced [BAKER-1966]. Due to the

\footnotetext{
${ }^{5}$ The cell parameter is a linear function of the oxygen content of the unit cell where hyperstoichiometry leads to a decreased cell parameter and hypostoichometry leads to an increased cell parameter.
} 
conflicting evidence presented here, by Haschke [HASCHKE-1998], and by Baker [BAKER1966], it is difficult to determine whether the hyperstoichiometric $\mathrm{UO}_{2}$ produced in this study is accurately characterized or a product of further oxidation during the analysis period. No uranium hydrides were detected.

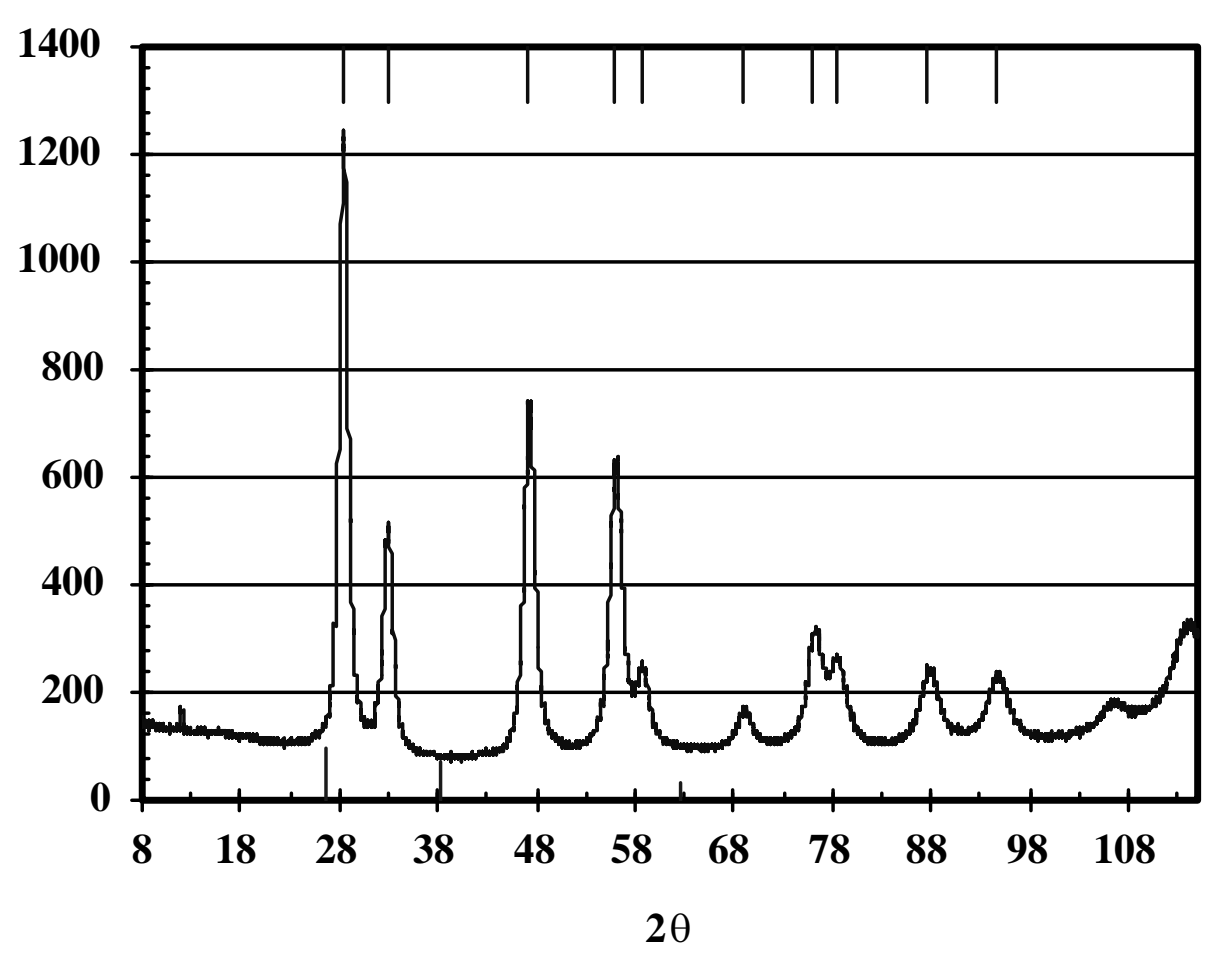

Fig. 9. X-ray Diffraction Pattern for Oxidized Uranium Metal in EJ13 at $90^{\circ} \mathrm{C}$ (the Markings at the Top of the Plot Show Expected Peak Positions for Uraninite and Those at the Bottom Show Expected Peak Positions for $\mathrm{UH}_{3}$, Ruling Out the Presence of Hydrides in Levels Sufficient for XRD Detection)

Included in the cell refinement is an estimate of the diffracting domain size based on the full width at half-maximum of the peaks. The domain size for this material is $<10 \mathrm{~nm}$, which does not necessarily mean that individual particle sizes are $10 \mathrm{~nm}$. But when one considers the TEM analysis of uranium colloids (see Section III.B.3) it is quite clear that uranium colloids are being generated as spheres with particle sizes of 5-10 nm. The TEM and XRD data then suggest that colloids are released into solution as a result of cleavage along crystal domains that form during the oxidation of the metal. Importantly then, the release of $\mathrm{UO}_{2+x}$ colloids occurs regardless of the presence of dissolved oxygen. If dissolved oxygen were a major participant, one would expect $\mathrm{UO}_{3}$-type colloids formed via dissolution and precipitation of dissolved uranyl species to dominate the colloid population. This conclusion is consistent with observations on the oxic and anoxic corrosion of uranium metal and occurrence of similar $\mathrm{UO}_{2+\mathrm{x}}$ colloids in unreported, oxic drip tests run at ANL. 


\section{Gas Generation}

As with UUBT1, the gas pressure was monitored (see Fig. 10). Pressurization could not be detected before day 6 because of a leaky gasket. Once again, there appears to be an induction period before the evolution of hydrogen defines the dominant corrosion mechanism. Compared to UUBT1 the oxygen levels in solution are extremely low, so it appears that the induction period is not a sensitive function of the $\mathrm{O}_{2}$ concentration in solution. That is to say, the presence of 1/10 the oxygen levels in ambient air (Test UUBT1) displayed an induction period identical, to within experimental error, to that observed in Test UUBT2 where $<50 \mathrm{ppm} \mathrm{O}_{2}$ was present. The pressure in the vessel begins to increase 10-14 days into the test. The linear period between days 14 and 54 was used to estimate an oxidation rate of $0.94 \mathrm{mg} / \mathrm{d}$ based on a least squares fit of the data and corresponds to an estimated corrosion of $39 \mathrm{mg}$ of fuel ( $46 \%$ of original fuel) during this period. If this value is normalized to the original fuel geometric surface area (assume same surface area as UUBT1, $23.2 \mathrm{~mm}^{2}$ ), a highly conservative corrosion rate of $4 \times 10^{5} \mathrm{mg} / \mathrm{m}^{2} / \mathrm{d}$ is obtained. No net production of gas was measured after day 55. A faulty gasket may have caused the failure to observe additional gas generation.

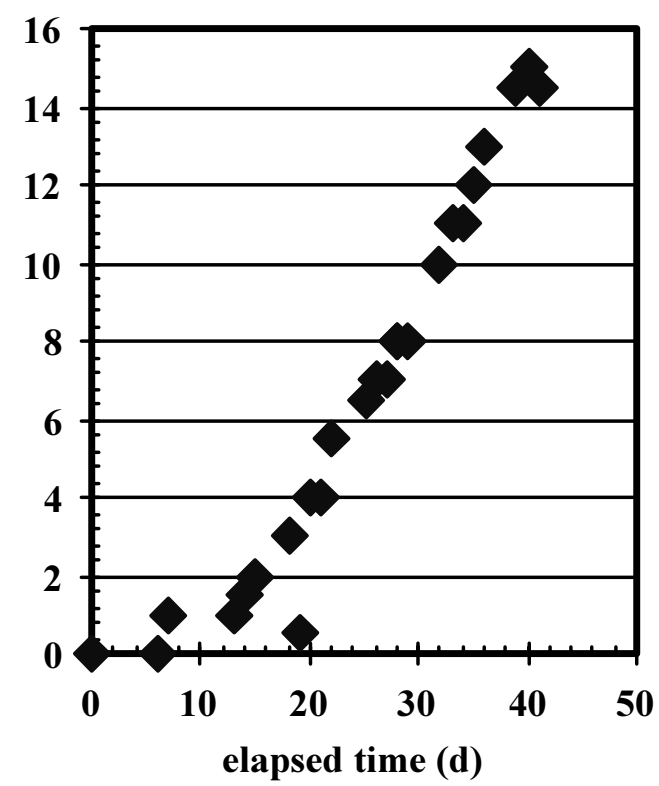

Fig. 10. The Inferred $\mathrm{H}_{2}$ Gas Produced during the Corrosion of $84.1 \mathrm{mg}$ of Uranium Metal in Test UUBT2

\section{3. $\quad$ Colloids}

The reacted solution was not analyzed for colloids until day 28 , at which time the colloid population was detectable by DLS. It subsequently increased to exceptionally 
high levels, indicated by extremely large scattering intensities for days 55 samples $\left(1100 \times 10^{3}\right.$ cps) and day 108 samples $\left(1790 \times 10^{3} \mathrm{cps}\right)$ as displayed in Table 6 . When the light scattering software could generate acceptable data fits, a wide distribution was computed. The polydispersity indices were reasonably low to have confidence in the distribution histograms for some measurements but could not be reproduced with certainty. Typical size distribution outputs were $300 \mathrm{~nm} \pm 300 \mathrm{~nm}$ at FWHM. Of note is the scattering signal from the experimental blank UUBB1 after day 116. The strong scattering intensity suggests that EJ-13 itself is susceptible to colloid production under anoxic conditions. The TEM analysis of filtrate revealed the presence of smectite clays. In addition, the TEM data that follows will show that components of EJ-13 are probably contributing significantly to the colloid population.

The dissolved uranium concentration at the initial sampling (360 ppb) was similar to that in days 6 and 17 of UUBT1 (colloids were not filtered until day 55). By day 55 uranium colloids were prevalent. As seen in Fig. 11, colloidal uranium accounted for nearly all the detectable uranium at 55 days and approximately half of the uranium in solution at day 108. It is noted that nickel was found in solution well in excess of its EJ-13 concentrations and was partitioned to the colloidal range suggesting that the stainless steel vessel may be contributing to the nature of some colloidal species. No other metals (e.g., Si, $\mathrm{Ca}, \mathrm{Fe}, \mathrm{Al})$ were found to be strongly partitioned to the colloidal phases based on solution analyses.

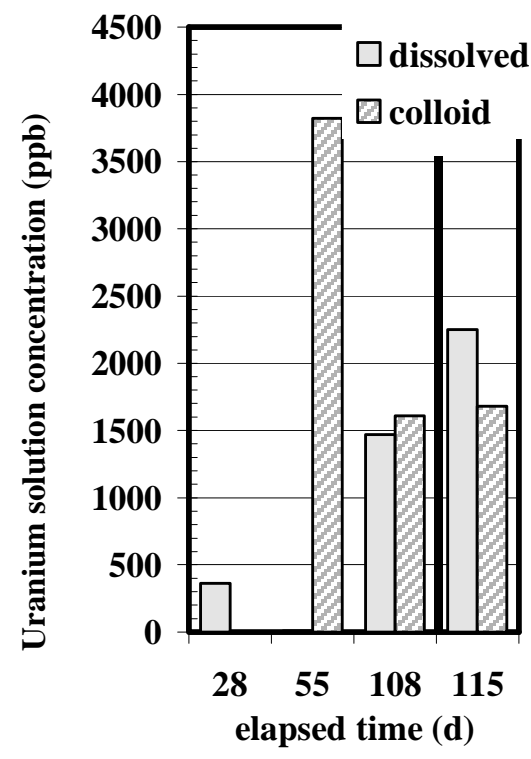

Fig. 11. Dissolved and Colloidal Uranium Concentrations in Solutions from Test UUBT2. (The vertical line indicates that the test was equilibrated with air after the sampling at 108 days.) 


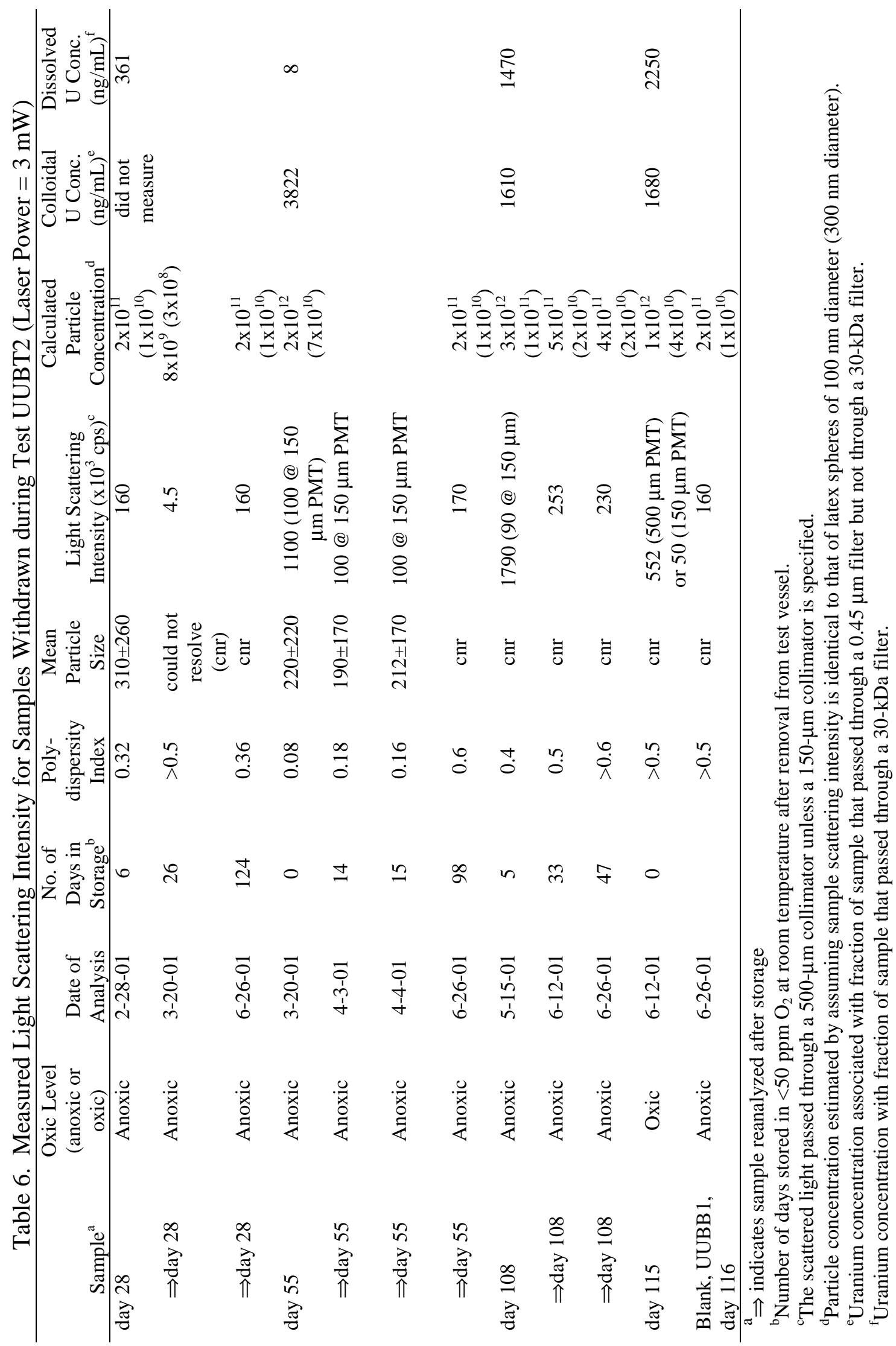


The unfiltered solution at day 55 was wicked through a holey carbon grid and analyzed by TEM. This analysis offers a more accurate method of determining the disposition of elements within colloids. The results are displayed in Fig. 12. Colloids appeared to be composed of $\mathrm{UO}_{2}$ spheres and smectite-type silicate clays. The uranium oxides existed as large agglomerates of tiny spheres $<10 \mathrm{~nm}$ in diameter (Fig. 12a) or attached to silicate clay host materials. The uranium agglomerations varied in size from $<50 \mu \mathrm{m}$ to $>200 \mu \mathrm{m}$. The morphology of the smectite clays (Fig. 12b) resembles that of layered clays found in waste glass corrosion [MERTZ-1999], with variations in size and shape. Not surprisingly, because of the nature of clays, $\mathrm{Fe}, \mathrm{Ni}$, and $\mathrm{Al}$ were found in association to varying degrees. The source of Fe may be either the EJ13 or the vessel and the source of Ni must be the corrosion of the vessel. This diversity of both the $\mathrm{UO}_{2}$ and silicate clay colloid morphology corroborates DLS measurements where size distribution data were difficult to reproduce due to large sample polydispersity.
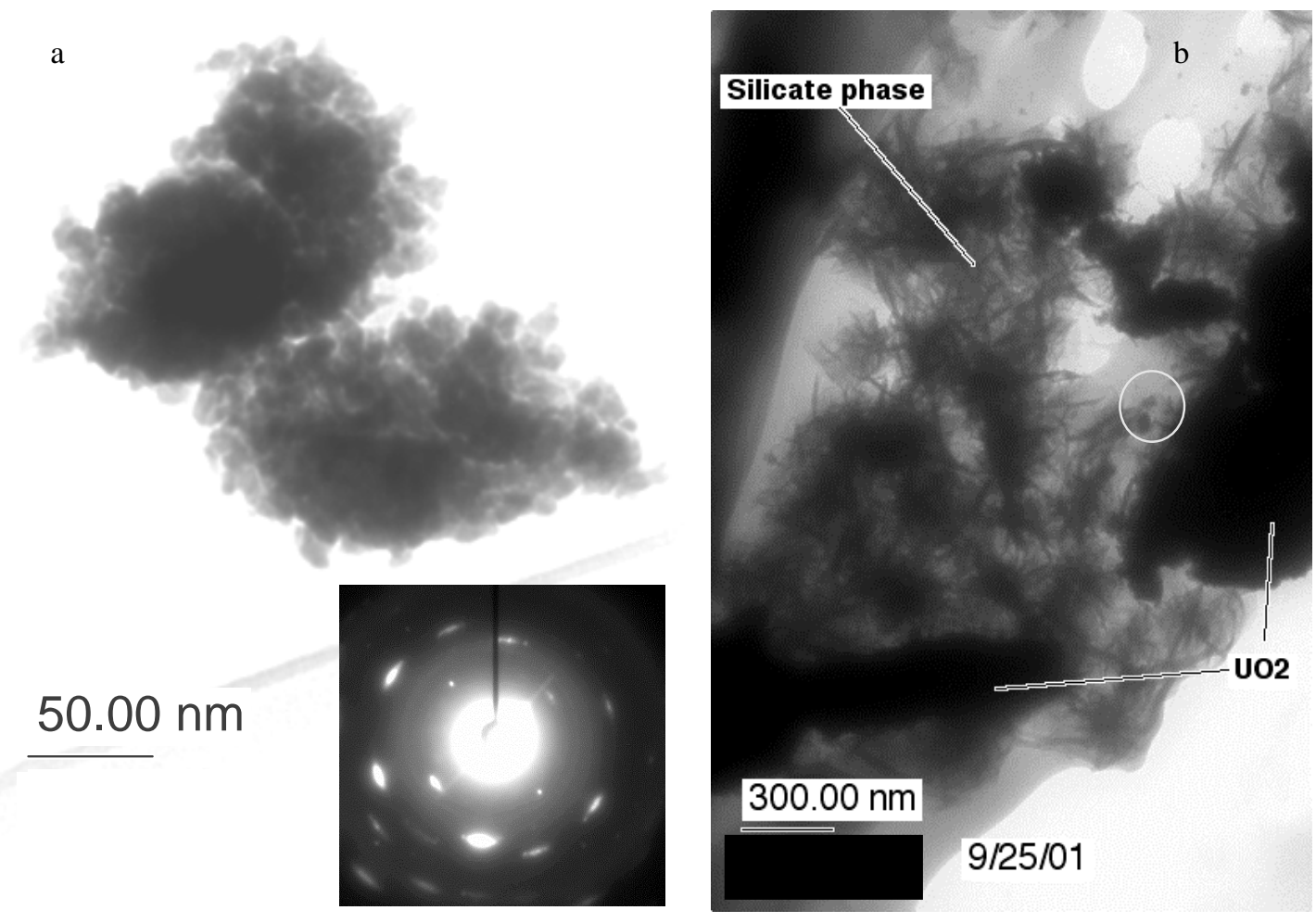

Fig. 12. TEM Images of Two Types of Colloids Found during Test UUBT2 Reveals (a) an Agglomeration of $\mathrm{UO}_{2}$ Spheres and Electron Diffraction Pattern of Similar Structure and (b) the Rippled Morphology Typical of a Layered Smectite Clay Structure. Note the $\mathrm{UO}_{2}$ spheres entrained in the clay (circled).

The stability of colloids was investigated as before and is shown in Table 6. Colloids collected at day 28 persisted in the sample after four months or storage 
with scattering intensity equal to the initial evaluation (2-28-01), while the colloid signal was reduced from $1100 \times 10^{3}$ cps to $170 \times 10^{3} \mathrm{cps}$ in the day 55 sample after three months storage. A similar decrease in signal intensity was observed after a one-month storage of the day 108 sample. The data suggest that uranium metal corrosion will produce copious amounts of colloids, which are at least partly unstable and will reduce in number with time. Still unknown is whether this instability is generated by changes in $\mathrm{pH}$, temperature, vessel material, or by the absence of a precipitated source material (i.e., the uranium oxide products controlled by the solubility index). Also, it is still to be determined whether the decrease in colloid signal is due to disappearance of either $\mathrm{UO}_{2}$ and clay or both.

This collection of data marked the termination of the anoxic tests. Test UUBT2 was restarted by exposing the vessel contents to normal air $\left(21 \% \mathrm{O}_{2}\right)$ and monitoring the effect on dissolved uranium and colloids. The next section summarizes the results of this short experiment.

\section{C. $\quad$ Oxic Testing}

After exposing the test UUBT2 to laboratory air for about 12 hours, the vessel was resealed and heated to $90^{\circ} \mathrm{C}$ as before. A sample was withdrawn at day 7 (115 days after UUBT2 initiation) and analyzed as previously described. The brown appearance of the spalled products was not visibly altered (e.g., no change in color) and the presence of colloids remained strong although the signal intensity did drop significantly, >1000 to $552 \mathrm{kcps}$ (see Table 6). Uranium associated with the colloids was determined by filtration and was comparable to day 108, although the dissolved uranium concentration was 50\% higher (see Fig. 11). There were no other significant differences between solution and colloidal elemental concentrations in the anoxic and oxic tests (see Table A4, Appendix A). Analysis of the colloids by TEM produced similar results as seen at 55 days, although calcium-rich colloids now were observed (see Fig. 13), in addition to $\mathrm{UO}_{2}$ and clay colloids. The clays incorporated $\mathrm{Al}, \mathrm{Ni}, \mathrm{Fe}$, and $\mathrm{Mg}$.

There appear to be at least two mechanisms governing the corrosion of metallic uranium fuel in well water at $90{ }^{\circ} \mathrm{C}$. The first mechanism appears to dominate the initial corrosion while the fuel is relatively intact. No gas pressurization occurs during this induction period. The second mechanism produces a net gas release, presumed to be $\mathrm{H}_{2}$, as the fuel is completely converted to a fine $\mathrm{UO}_{2}$ powder. 


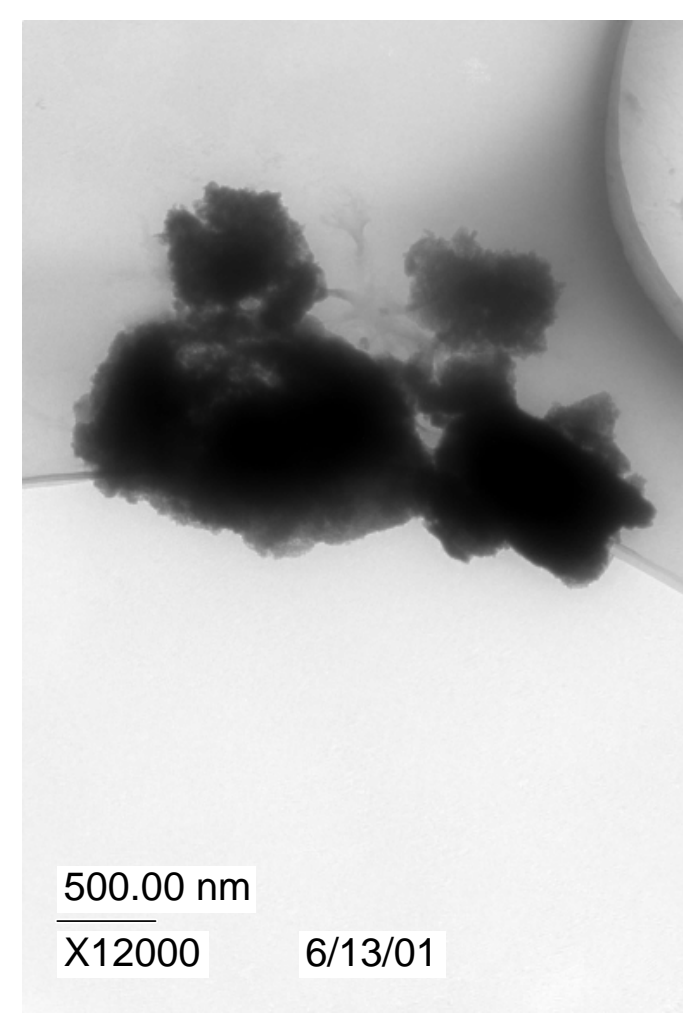

Fig. 13. Transmission Electron Micrographs of Calcium-Rich Colloids Collected at Day 115 under Oxic Conditions in Test UUBT2. No other elements were detected by X-ray analysis of this colloid (oxygen could not be determined).

\section{DISCUSSION}

The induction periods were 6 weeks and 1-2 weeks for test UUBT1 $\left(2 \% \mathrm{O}_{2}\right.$ in $\left.\mathrm{N}_{2}\right)$ and UUBT2 $\left(<100 \mathrm{ppm} \mathrm{O}_{2}\right.$ in $\left.\mathrm{N}_{2}\right)$, respectively. If the induction period were a direct function of oxygen available in the test vessel, no induction period would have been expected to occur in UUBT2. Based on oxygen availability one can compute the fraction, $f$, of uranium that can be oxidized according to Eq. 3. For UUBT1, assume that the vessel was in equilibrium with the glovebox air $\left(C_{O_{2}}=0.2 \mathrm{~mol}\right.$ fraction) at each sampling (five samplings), and that all the $\mathrm{O}_{2}$ (dissolved and in vessel head-space) is available for reaction. The dissolved component turns out to be insignificant compared to the $\mathrm{O}_{2}$ available in the headspace of the vessel. Using this approach the following fraction can be computed: 


$$
\frac{\left(C_{O_{2}} \frac{V_{\text {head }}}{22.4 \times 10^{3}}\right) / 2}{\left(m_{U} \frac{1}{238 \times 10^{3}}\right)} \times 100 \times n=f_{U \rightarrow U O_{2}}=6 \%
$$

where $V_{\text {head }}$ is the headspace volume in the vessel $(7-11 \mathrm{~mL}), 22.4 \times 10^{3}$ is the conversion factor for moles of air per $\mathrm{mL}, 1 / 2$ is the stochiometric ratio from Eq. 3 where $x=0, m_{U}$ is the mass of uranium metal in $\mathrm{mg}, 238 \times 10^{3}$ is the conversion factor for moles of $\mathrm{U}$ per $\mathrm{mg}$ of fuel, and $n$ is the number of times the vessel was sampled. Thus, the total oxygen available to the fuel can roughly account for $6 \%$ of the oxidized fuel, at which time $\mathrm{H}_{2}$ production under Eq. 6 should dominate. And yet, the pressurization calculations show that $\mathrm{H}_{2}$ can account for only $<50 \%$ of the oxidized fuel. Using this exercise for test UUBT2, where the $\mathrm{O}_{2}$ levels were $>1000$ times lower than in UUBT1, it is quite obvious that oxygen should not be a factor in the corrosion of the fuel. The results suggest that the corrosion of uranium under saturated anoxic conditions does not follow Eq. 2 exclusively. There must be additional mechanisms to account for the reduced $\mathrm{H}_{2}$ production and the induction period corrosion. One such mechanism is removal of $\mathrm{H}_{2}$ during the formation of uranium hydrides via Eq. 19, which would produce an accumulation of $\mathrm{UH}_{3}$ that would subsequently release hydrogen by reaction with water:

$$
2 \mathrm{UH}_{3}+4 \mathrm{H}_{2} \mathrm{O} \rightarrow 2 \mathrm{UO}_{2}+7 \mathrm{H}_{2} \text {. }
$$

Baker et al. [BAKER-1966] showed that $\mathrm{UH}_{3}$ formation increased as the relative humidity and temperature increased producing up to $13 \%$ hydride under flowing gas conditions. The static conditions of this test may contribute to hydride concentrations higher than $13 \%$. The similarities in density between hydride $\left(10.95 \mathrm{~g} / \mathrm{cm}^{3}\right)$ and oxide $\left(11-11.3 \mathrm{~g} / \mathrm{cm}^{3}\right)$ suggest that both products could grow intimately without developing sufficiently large stresses. The lack of hydride in the diffraction analysis reduces the credibility of this argument although hydrides may have reacted with water to produce $\mathrm{UO}_{2}$ before analysis could be completed. Reasons for the observed induction period needs further investigation.

Of prominent importance, colloids were generated in copious quantities compared to corrosion of other fuel types such as MOX [MERTZ-2001a], UAl [KAMINSKI2001], and $\mathrm{UO}_{2}$ [MERTZ-2001b]. These colloids are composed of isolated $(<10 \mathrm{~nm})$ or agglomerated uranium dioxide spheres and smectite clays. The agglomerated spheres and clay material displayed a variety of sizes from $<50 \mathrm{~nm}$ to $>500 \mathrm{~nm}$. Light scattering measurements confirmed the polydispersity of the colloids and high colloid populations. Using the scattering intensities, colloid densities as high as $10^{12}$ particles/L were estimated. Uranium was associated with the colloid fraction in substantial concentrations: as much as $98.2 \%$ of the uranium released into solution (Test UUBT2, day 55). In this sample, the colloidal uranium concentration was $1.6 \times 10^{-5} \mathrm{M}$, as opposed to a dissolved concentration of $3 \times 10^{-8} \mathrm{M}$. The $\mathrm{UO}_{2+\mathrm{x}}$ colloid spheres appear to form via cleavage along crystal domains $5-10 \mathrm{~nm}$ in size that are produced during the direct oxidation of the material as shown by X-ray diffraction. This is an important finding because it suggests that colloidal $\mathrm{UO}_{2}$ is released directly during oxidation and is not 
limited to the kinetics of oxidation, dissolution, and precipitation of uranyl-type colloids. The colloids produced in the fuel tests are at least partially stable for the durations monitored under this short program.

\section{FUTURE WORK}

The next phase in the testing of uranium metal fuel encompasses identical testing methodology for irradiated N-Reactor fuels. These tests have begun and will continue through the end of FY2001. Gas samples will be collected and analyzed as well to confirm the generation of $\mathrm{H}_{2}$ gas. As part of the irradiated fuel testing program, the colloid samples collected under the unirradiated program discussed in this report will continue to be monitored for stability and paragenesis, as will colloid fractions generated by the fully irradiated fuels. The stability of colloids will be explored as to the effects from $\mathrm{pH}$ change and dilution. Finally, the colloids generated during the blank test UUBB1 will be examined further as to characterization and stability.

\section{ACKNOWLEDGMENTS}

Modifications to the glovebox and Parr vessels were completed by J. Emery and M. Clark. The water analysis performed by S. Wolf and Y. Tsai was much appreciated. Also, thanks to J. Holly and J. Fortner for TEM and electron diffraction analysis, B. Finch for XRD analysis, and C. Mertz for sample preparation and assistance with DLS experiments. This work was supported by the U.S. Department of Energy, under contract W-31-109-ENG-38. 


\section{REFERENCES}

[BAKER-1966]

M. McD. Baker, L. N. Less, and S. Orman, Trans. Faraday Soc., 62, 2513, 1966.

[COLMENARES-1984]

C. A. Colmenares, Prog. Solid State Chem., 15, 257-364, 1984.

[MERTZ-2001a]

C. J. Mertz, personal communication with C. Mertz on the laser light scattering intensity for filtrate from MOX drip test at ANL, July 2001.

[MERTZ-2001b]

C. J. Mertz, personal communication with C. Mertz on the laser light scattering intensity for filtrate from commercial $\mathrm{UO}_{2}$ fuel drip test at ANL, July 2001.

[FORTNER-2001]

J. A. Fortner, C. J. Mertz, M. M. Goldberg, and C. V. Shelton-Davis, "Corrosive Alteration of N-Reactor Fuel Exposed to Simulated Groundwater," Proceedings of the $9^{\text {th }}$ International High-Level Radioactive Waste Management Conference, Las Vegas, NV, April 29-May 3, 2001.

[HASCHKE-1998]

J. M. Haschke, J. Alloys Comp., 278, 149-160, 1998.

[KAMINSKI-2001]

M. D. Kaminski and M. M. Goldberg, "Corrosion of Breached Aluminide Fuels Under Potential Repository Conditions," Proceedings of the $9^{\text {th }}$ International High-Level Radioactive Waste Management Conference, Las Vegas, NV, April 29-May 3, 2001.

[MCGILLIVRAY-1994]

G. W. McGillivray, D. A. Geeson, and R. C. Greenwood, J. Nucl. Mat., 208, 81-97, 1994.

[MERTZ-1999]

C. Mertz, "Colloid-Associated Radionuclide Concentration Limits," Office of Civilian Radioactive Waste Management Analysis Model Report, ANL-EBS-MD-000020 REV 00 ICN 01, June 20, 1999.

[ORMAN-1964]

S. Orman, Uranium, Compatibility Studies, Part 2: The Effect of Water Vapour Pressure in an Oxygen Free Atmosphere on the Corrosion Rate of Uranium at $100^{\circ} \mathrm{C}$, Atomic Weapons Research Establishment Report No. O-25/64, 1964.

[RITCHIE-1981]

A. G. Ritchie, J. Nucl. Mater., 102, 170-182, 1981. 
[WABER-1952]

J. T. Waber, Review of the Corrosion of Uranium and its Alloys, Los Alamos National Laboratory Report, LA-1524, 1952.

[WEIRICK-1984]

L. J. Weirick, The Oxidation of uranium in Low Partial Pressures of Oxygen and Water Vapor at 100 C, Report SAND-83-0618, Sandia National Laboratories, Albuquerque, NM, June 1984.

[WOLF-1998]

S. F. Wolf, J. Radioanal. Nucl. Chem., 235, 1-2, 207-212, 1998. 
APPENDIX A

Raw Data and Measurement Tables 


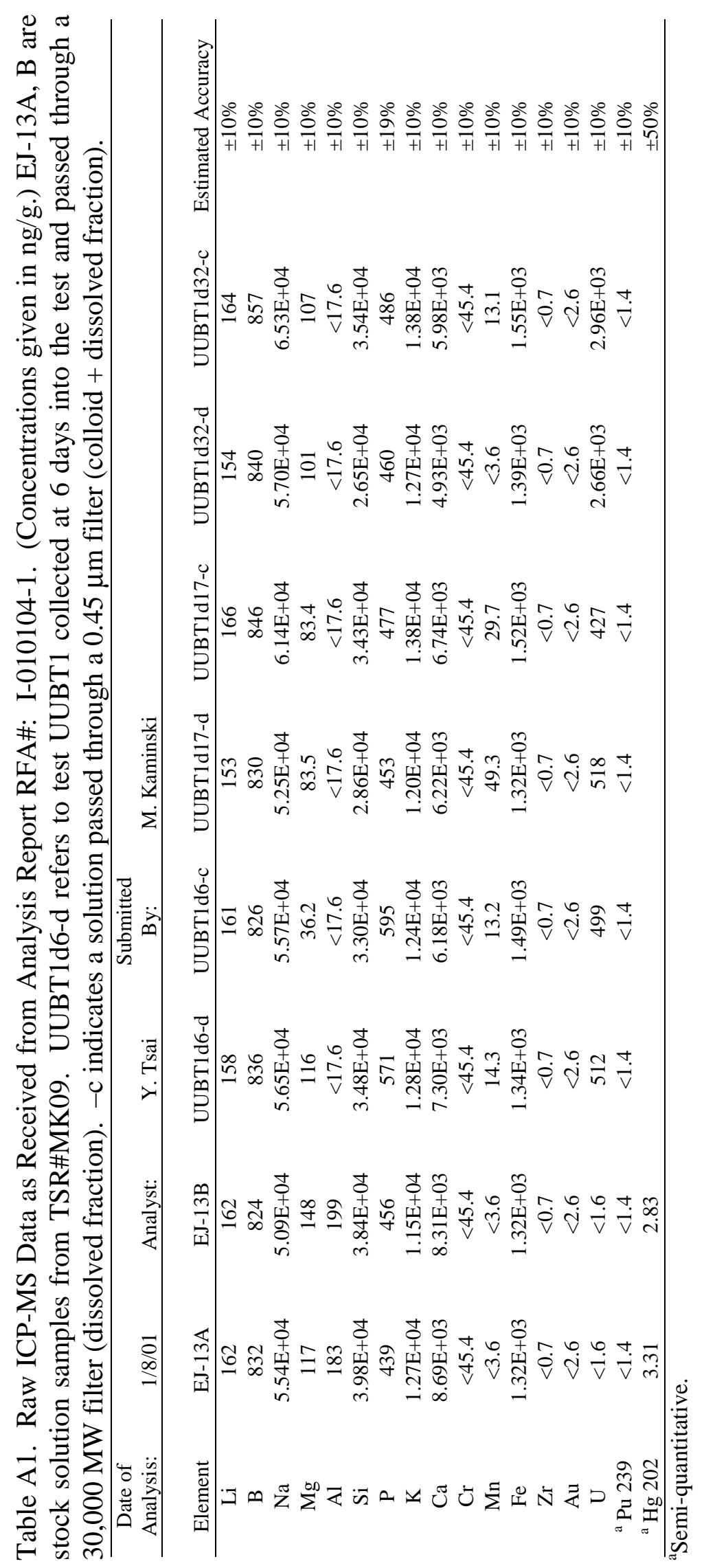


Table A2. Raw ICP-MS Data as Received from Analysis Report RFA\#: I-010327-3. (Concentrations given in $\mathrm{ng} / \mathrm{g}$, stock bottle TSR\#MDK09 were sparged with $\mathrm{N}_{2}$ gas and stored in the containment box. "EJ-D28" was sampled during the sampling of UUBT2 at day 28 on 2-22-01 and "EJ-13, 4-3-01" was sampled on 4-3-01.)

\begin{tabular}{|c|c|c|}
\hline $\begin{array}{c}\text { Date of Analysis: } \\
\text { Submitted by: } \\
\text { Analyst: }\end{array}$ & \begin{tabular}{l}
\multicolumn{1}{c}{$4 / 3 / 01$} \\
M. Kaminski \\
Y. Tsai
\end{tabular} & \\
\hline Element & EJ-D28 & EJ-13, 4-3-01 \\
\hline $\mathrm{Li}$ & $<8.3$ & $<8.3$ \\
\hline $\mathrm{B}$ & 445 & 385 \\
\hline $\mathrm{Na}$ & $4.12 \mathrm{E}+04$ & $4.06 \mathrm{E}+04$ \\
\hline $\mathrm{Mg}$ & 276 & 256 \\
\hline $\mathrm{Al}$ & 550 & 538 \\
\hline $\mathrm{Si}$ & $3.20 \mathrm{E}+04$ & $3.23 \mathrm{E}+04$ \\
\hline $\mathrm{P}$ & 358 & 438 \\
\hline $\mathrm{K}$ & $8.82 \mathrm{E}+03$ & $8.30 \mathrm{E}+03$ \\
\hline $\mathrm{Ca}$ & $7.58 \mathrm{E}+03$ & $7.60 \mathrm{E}+03$ \\
\hline $\mathrm{Cr}$ & 2.43 & 2.4 \\
\hline $\mathrm{Mn}$ & 2.1 & 1.91 \\
\hline $\mathrm{Fe}$ & $<338$ & $<338$ \\
\hline $\mathrm{Ni}$ & 17.7 & 4.38 \\
\hline $\mathrm{Sr}$ & 37.7 & 36.3 \\
\hline $\mathrm{Zr}$ & 1.07 & 1.73 \\
\hline $\mathrm{Ru}$ & $<0.4$ & $<0.4$ \\
\hline $\mathrm{Cs}$ & 1.57 & 1.56 \\
\hline $\mathrm{Au}$ & 1.09 & 1.04 \\
\hline $\mathrm{U}$ & 1.4 & 0.396 \\
\hline${ }^{\mathrm{a}}$ Tc 99 & $<0.1$ & $<0.1$ \\
\hline${ }^{\mathrm{a}} \mathrm{Np} 237$ & $<0.1$ & $<0.1$ \\
\hline${ }^{\mathrm{a}} \mathrm{Pu} 239$ & $<0.1$ & $<0.1$ \\
\hline${ }^{\mathrm{a}} \mathrm{Am} 241$ & $<0.1$ & $<0.1$ \\
\hline${ }^{\mathrm{a}} \mathrm{Cm} 244$ & $<0.1$ & $<0.1$ \\
\hline${ }^{\mathrm{a}} \mathrm{Cs} 137$ & 0.242 & 0.482 \\
\hline${ }^{\mathrm{a}} \mathrm{Sr} 90$ & 0.710 & 0.574 \\
\hline
\end{tabular}

${ }^{a}$ Semi-quantitative. 
Table A3. Raw ICP-MS Data as Received from Analysis Report RFA\#: I-010327-3. (Concentrations given in $\mathrm{ng} / \mathrm{g}$ ). Sample ID Coded as in Table A1.

Date of 4/3/01

analysis:

Submitted by: M. Kaminski

Dilution Factor

10

10

Analyst: $\quad$ Y. Tsai

Element UUBT2d28-c UUBT2d55-d UUBT2d55-c Estimated Accuracy

\begin{tabular}{ccccc}
\hline $\mathrm{Li}$ & $<8.3$ & $<8.3$ & $<8.3$ & $\pm 10 \%$ \\
$\mathrm{~B}$ & 397 & 363 & 348 & $\pm 10 \%$ \\
$\mathrm{Na}$ & $4.86 \mathrm{E}+04$ & $5.48 \mathrm{E}+04$ & $4.26 \mathrm{E}+04$ & $\pm 10 \%$ \\
$\mathrm{Mg}$ & 50.4 & 52.7 & 67.9 & $\pm 10 \%$ \\
$\mathrm{Al}$ & 145 & 124 & 195 & $\pm 10 \%$ \\
$\mathrm{Si}$ & $2.71 \mathrm{E}+04$ & $1.48 \mathrm{E}+04$ & $1.50 \mathrm{E}+04$ & $\pm 10 \%$ \\
$\mathrm{~K}$ & $1.01 \mathrm{E}+04$ & $1.14 \mathrm{E}+04$ & $1.28 \mathrm{E}+04$ & $\pm 10 \%$ \\
$\mathrm{Ca}$ & $1.43 \mathrm{E}+03$ & $1.19 \mathrm{E}+03$ & $1.02 \mathrm{E}+03$ & $\pm 10 \%$ \\
$\mathrm{Cr}$ & 4.79 & 5.16 & 6.67 & $\pm 10 \%$ \\
$\mathrm{Fe}$ & $<345$ & $<345$ & $<345$ & $\pm 10 \%$ \\
$\mathrm{Ni}$ & 180 & 38.1 & 178 & $\pm 10 \%$ \\
$\mathrm{U}$ & 361 & 8.21 & $3.83 \mathrm{E}+03$ & $\pm 10 \%$ \\
\hline
\end{tabular}




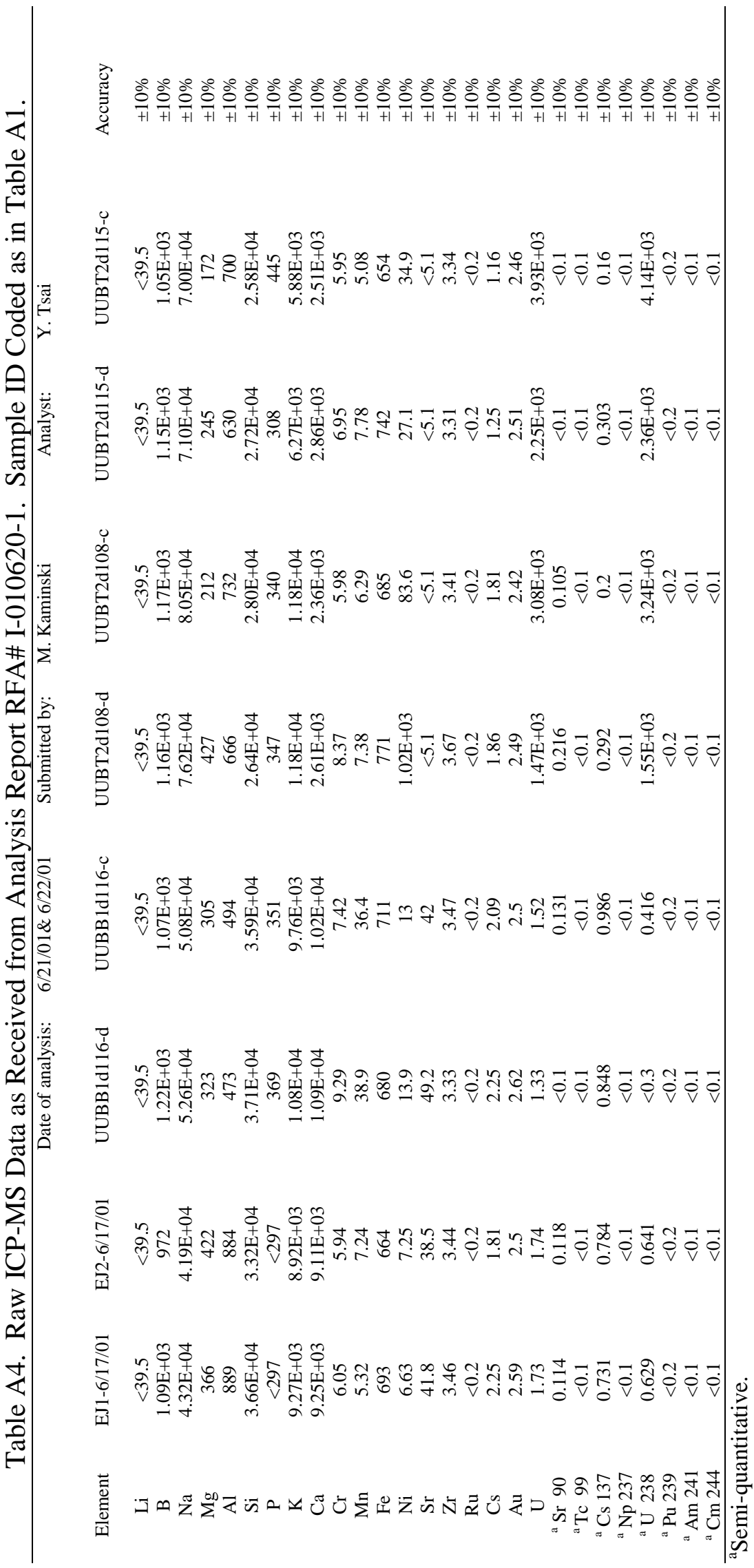


Table A5. Test Vessel Pressure Measurements Used to Estimate Uranium Oxidation Rates for Test UUBT1

\begin{tabular}{cccccc}
\hline Date & $\begin{array}{c}\text { Reading } \\
\text { (psig) }\end{array}$ & $\begin{array}{c}\mathrm{H}_{2} \text { Pressure } \\
(\mathrm{psig})\end{array}$ & $\begin{array}{c}\text { Elapsed \# } \\
\text { of Days }\end{array}$ & $\begin{array}{c}\mathrm{H}_{2} \text { Generated } \\
\text { (moles) }\end{array}$ & $\begin{array}{c}\text { Uranium Oxidized } \\
\text { (g of metal) }\end{array}$ \\
\hline 6-Nov & 11 & 0 & 0 & $0.0 \mathrm{E}+00$ & $0.0 \mathrm{E}+00$ \\
14-Nov & 16 & 5 & 8 & $1.2 \mathrm{E}-04$ & $1.5 \mathrm{E}-02$ \\
16-Nov & 18.5 & 7.5 & 10 & $1.8 \mathrm{E}-04$ & $2.2 \mathrm{E}-02$ \\
20-Nov & 22 & 11 & 14 & $2.7 \mathrm{E}-04$ & $3.2 \mathrm{E}-02$ \\
22-Nov & 23 & 12 & 16 & $3.0 \mathrm{E}-04$ & $3.5 \mathrm{E}-02$ \\
27-Nov & 25.25 & 14.25 & 21 & $3.5 \mathrm{E}-04$ & $4.2 \mathrm{E}-02$ \\
28-Nov & 25.1 & 14.1 & 22 & $3.5 \mathrm{E}-04$ & $4.1 \mathrm{E}-02$ \\
11-Dec & 25.25 & 14.25 & 35 & $3.5 \mathrm{E}-04$ & $4.2 \mathrm{E}-02$ \\
\hline
\end{tabular}

Table A6. Test Vessel Pressure Measurements Used to Estimate Uranium Oxidation Rates for Test UUBT2

\begin{tabular}{cccccc}
\hline Date & $\begin{array}{c}\text { Reading } \\
\text { (psig) }\end{array}$ & $\begin{array}{c}\mathrm{H}_{2} \text { Pressure } \\
\text { (psig) }\end{array}$ & $\begin{array}{c}\text { Elapsed } \\
\text { \# of days }\end{array}$ & $\begin{array}{c}\mathrm{H}_{2} \text { Generated } \\
\text { (moles) }\end{array}$ & $\begin{array}{c}\text { Uranium Oxidized } \\
\text { (g of metal) }\end{array}$ \\
\hline 25-Jan & 0 & 0 & 0 & 0 & 0 \\
31-Jan & 8 & 0 & 6 & 0 & 0 \\
1-Feb & 9 & 1 & 7 & $1.6016 \mathrm{E}-05$ & 0.0019059 \\
7-Feb & 9 & 1 & 13 & $1.6016 \mathrm{E}-05$ & 0.0019059 \\
8-Feb & 9.5 & 1.5 & 14 & $2.4024 \mathrm{E}-05$ & 0.00285885 \\
9-Feb & 10 & 2 & 15 & $3.2032 \mathrm{E}-05$ & 0.0038118 \\
12-Feb & 11 & 3 & 18 & $4.8048 \mathrm{E}-05$ & 0.00571769 \\
13-Feb & 8.5 & 0.5 & 19 & $8.008 \mathrm{E}-06$ & 0.00095295 \\
14-Feb & 12 & 4 & 20 & $6.4064 \mathrm{E}-05$ & 0.00762359 \\
15-Feb & 12 & 4 & 21 & $6.4064 \mathrm{E}-05$ & 0.00762359 \\
16-Feb & 13.5 & 5.5 & 22 & $8.8088 \mathrm{E}-05$ & 0.01048244 \\
19-Feb & 14.5 & 6.5 & 25 & 0.0001041 & 0.01238833 \\
20-Feb & 15 & 7 & 26 & 0.00011211 & 0.01334128 \\
21-Feb & 15 & 7 & 27 & 0.00011211 & 0.01334128 \\
22-Feb & 16 & 8 & 28 & 0.00012813 & 0.01524718 \\
22-Feb & 12 & 0 & 28 & 0, sampled & 0 \\
23-Feb & 12 & 0 & 29 & 0 & 0 \\
26-Feb & 14 & 2 & 32 & $3.2032 \mathrm{E}-05$ & 0.0038118 \\
27-Feb & 15 & 3 & 33 & $4.8048 \mathrm{E}-05$ & 0.00571769 \\
28-Feb & 15 & 3 & 34 & $4.8048 \mathrm{E}-05$ & 0.00571769 \\
1-Mar & 16 & 4 & 35 & $6.4064 \mathrm{E}-05$ & 0.00762359 \\
2-Mar & 17 & 5 & 36 & $8.008 \mathrm{E}-05$ & 0.00952949 \\
5-Mar & 18.5 & 6.5 & 39 & 0.0001041 & 0.01238833 \\
6-Mar & 19 & 7 & 40 & 0.00011211 & 0.01334128 \\
7-Mar & 18.5 & 6.5 & 41 & 0.0001041 & 0.01238833 \\
20-Mar & 23 & 11 & 54 & 0.00017618 & 0.02096487 \\
\hline
\end{tabular}




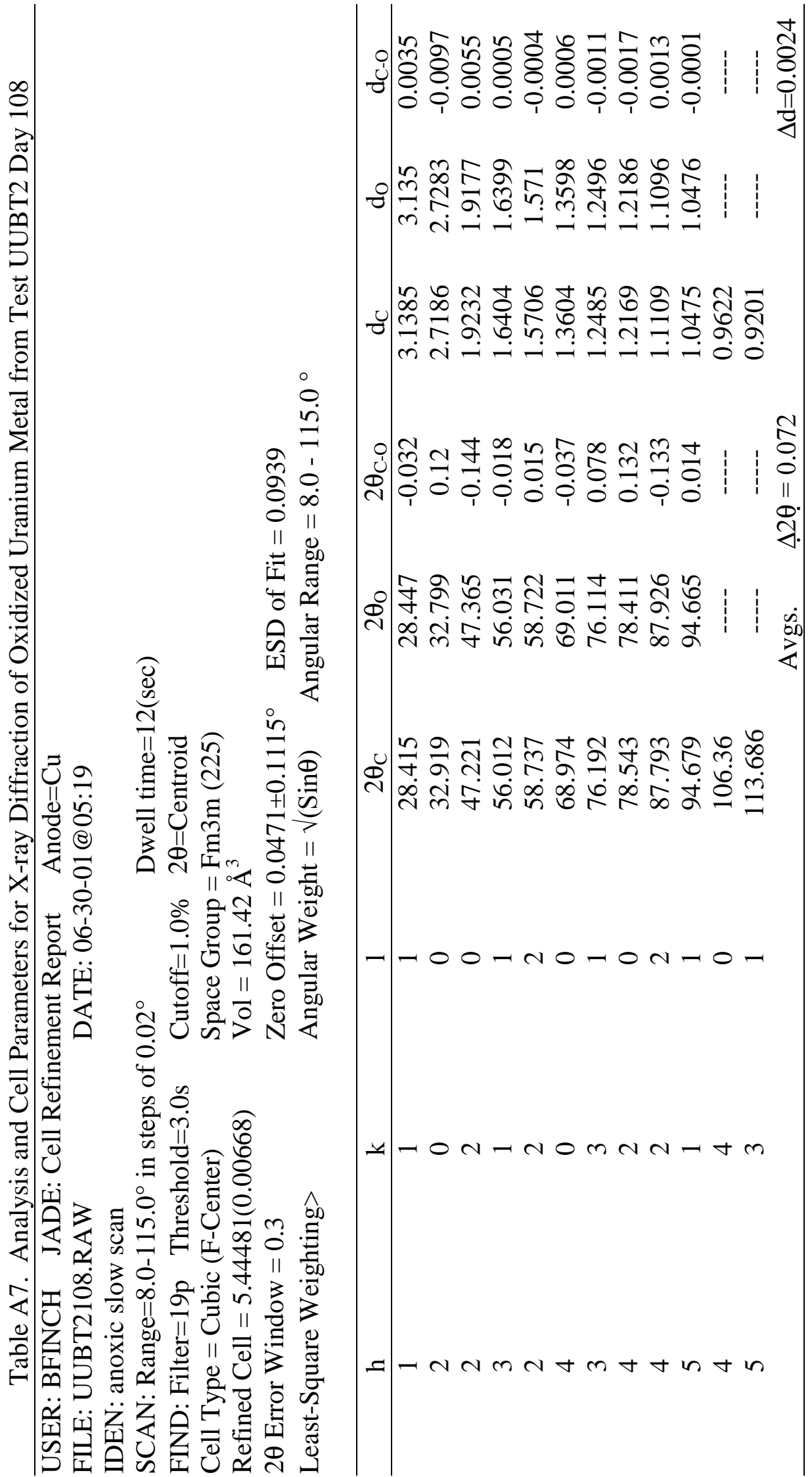




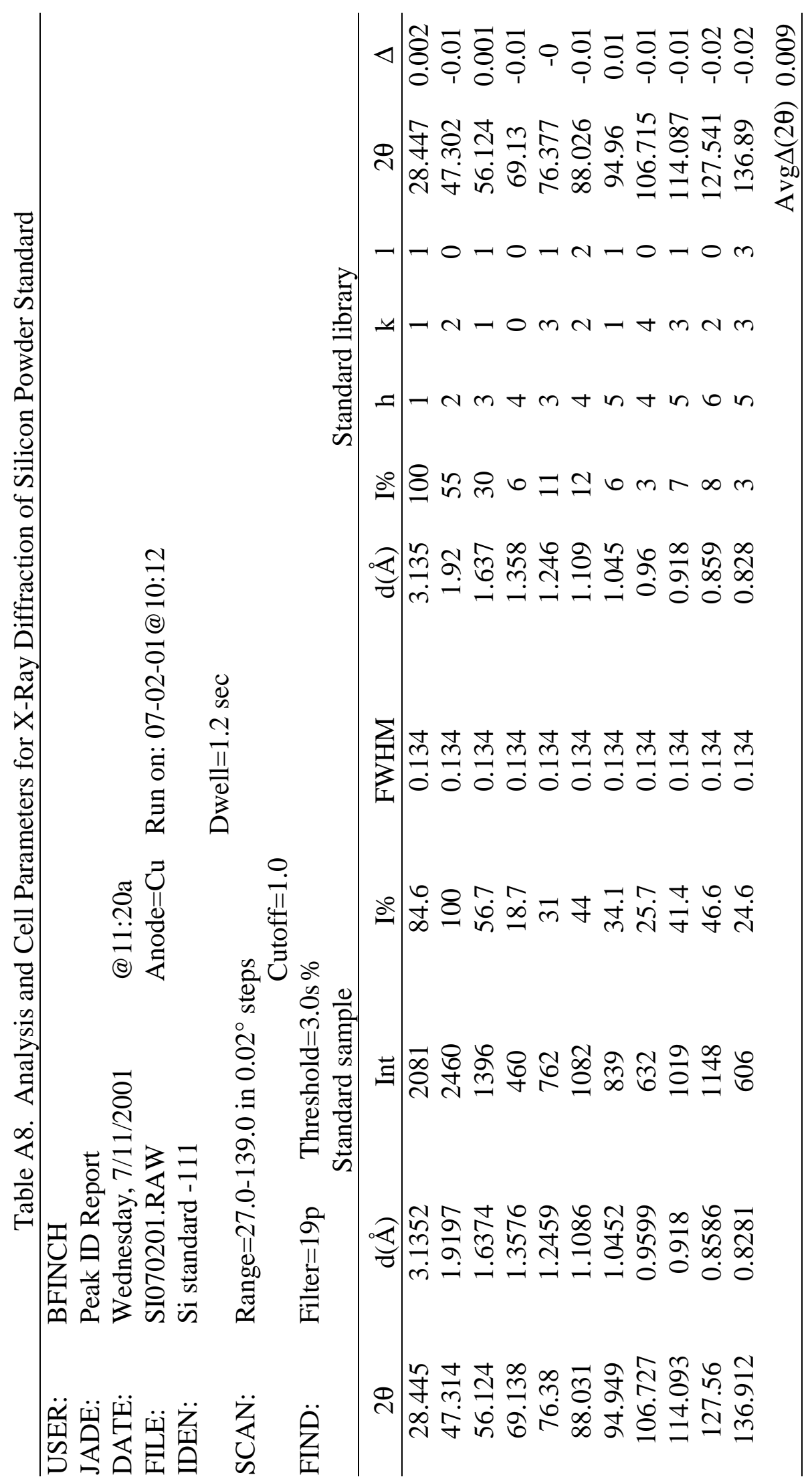




\section{APPENDIX B}

\section{TEM Reports}

This section reproduces the TEM Analysis Reports supplied by J. Holly et al. for samples UUBT2 collected at 55, 108, and 115 days. No additional annotations were incorporated except those provided by J. Holly et al. 
TEM Survey Report for Mike Kaminski

April 24, 2001

Microscopy Analyst: Jennifer Holly

Sample ID: UUBT2D55

Colloid sample \# C423

This sample was analyzed during the third week of April. There are nine images and nine EDS spectra in the pages that follow. The particles appear to be as small as $10 \mathrm{~nm}$. They are clustered into masses ranging in size from $200 \mathrm{~nm}$ down to $50 \mathrm{~nm}$. The images and spectra acquired are found in the pages that follow. All the copper peaks are artifacts due to the copper grid. A summary table lists the images and the EDS findings.

Sample ID: TEM Colloids Grid C423 from Sample UUBT2D55 for Mike Kaminski

$$
\text { Digital }
$$

Notebook Ref. Image Nos. Comments and Elements identified by EDS

SN1718:79 $\quad 1853 \quad$ Low magnification overview of several particles.
EDS was not performed.

SN1718:79 $\quad 1854 \quad$ Al, Si, S, Fe, Ti or Sc? As or Se and Uranium.

SN1718:79 $\quad 1855 \quad$ Large amounts of Si and Ni, Smaller amounts of $\mathrm{Fe}, \mathrm{Al}, \mathrm{S}, \mathrm{Cl}, \mathrm{Ca}$, and $\mathrm{Zn}$. There may also be Uranium present in a very small amount. The only peak visible for Uranium is at 3.171.

SN1718:79

SN1718:78

SN1718:80

SN1718:80

SN1718:80

SN1718:80
1856

1857

1858

1859

1860 $\mathrm{Al}, \mathrm{Si}, \mathrm{Cl}$, Ti or $\mathrm{V}$ ? $\mathrm{Fe}, \mathrm{Se}$ ? and Uranium. $\mathrm{Al}, \mathrm{Si}, \mathrm{S}, \mathrm{Cl}$, Ti or V?, Fe, Zn, Se?, and Uranium. $\mathrm{Al}, \mathrm{Si}, \mathrm{S}, \mathrm{Cl}$, , Ti or V?, Fe, Se?, and Uranium. CCD 1859 is a low magnification overview of three particles. EDS 1859 is of particle 1 in CCD 1859.

EDS spectrum identified Al, Si, S, Fe, Se?, and Uranium.

CCD 1860 is a high magnification image of particles 1 and 2 in CCD 1859. EDS 1860 is of particle 2 .

EDS spectrum identified Al, Si, S, Fe, Se?, and Uranium.

1861 CCD 1861 is a high magnification image of particle 3 in CCD 1859. The EDS is also of particle 3. EDS spectrum identified Al, Si, S, Fe, Se?, and Uranium. 


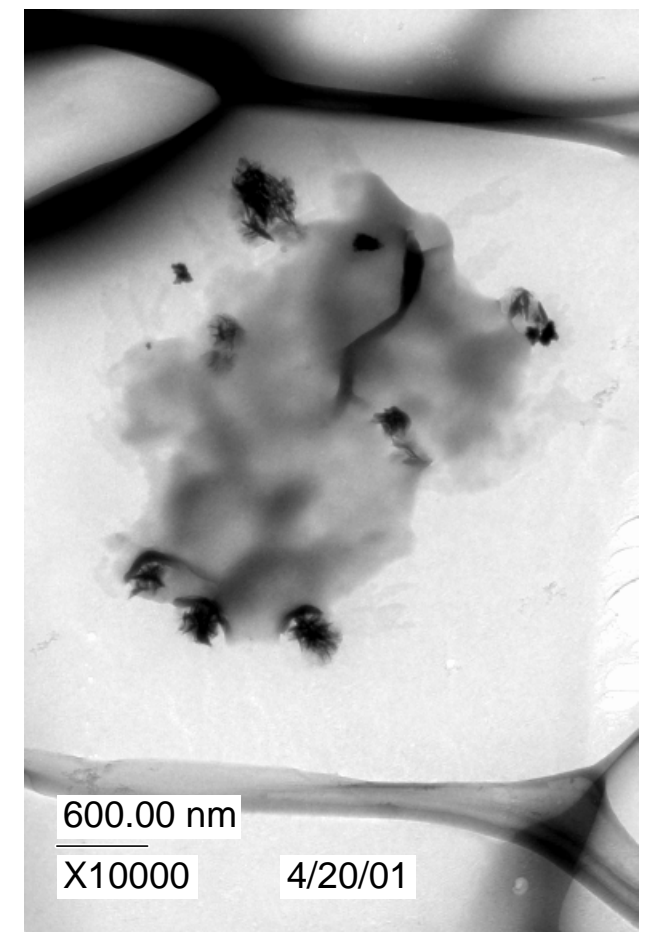

CCD 1853 - This is a low magnification overview of several particles. EDS was not performed. CCD images 1854-1857 are higher magnifications of particles in this image.

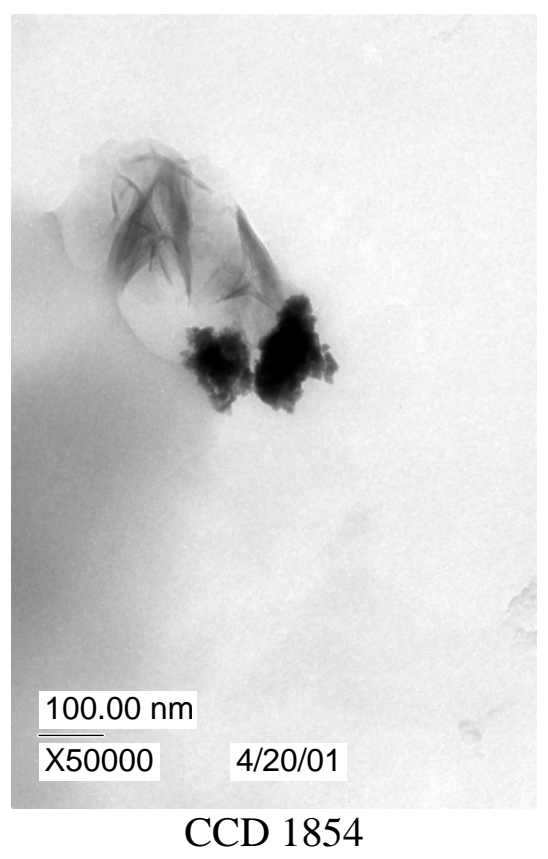

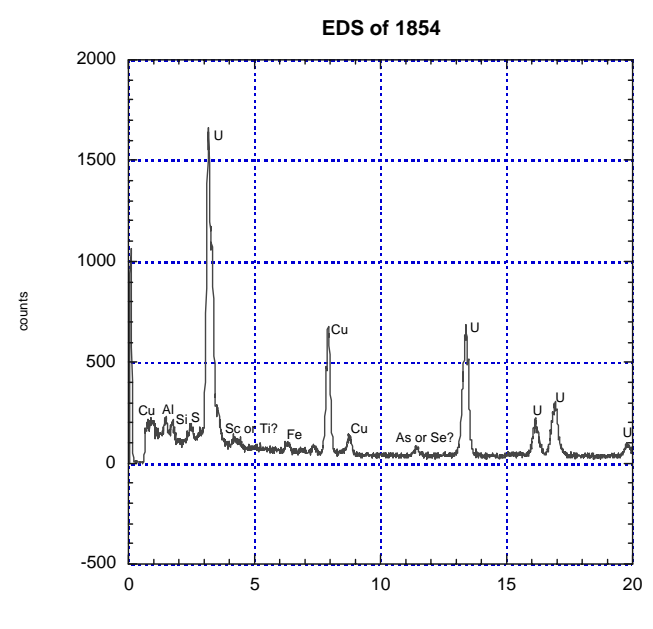

EDS of the Two Particles in CCD 1854

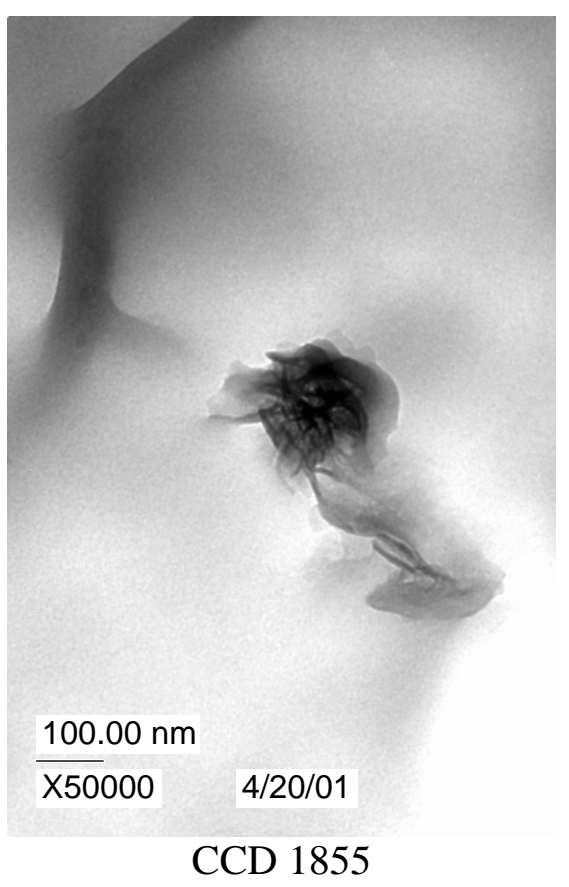




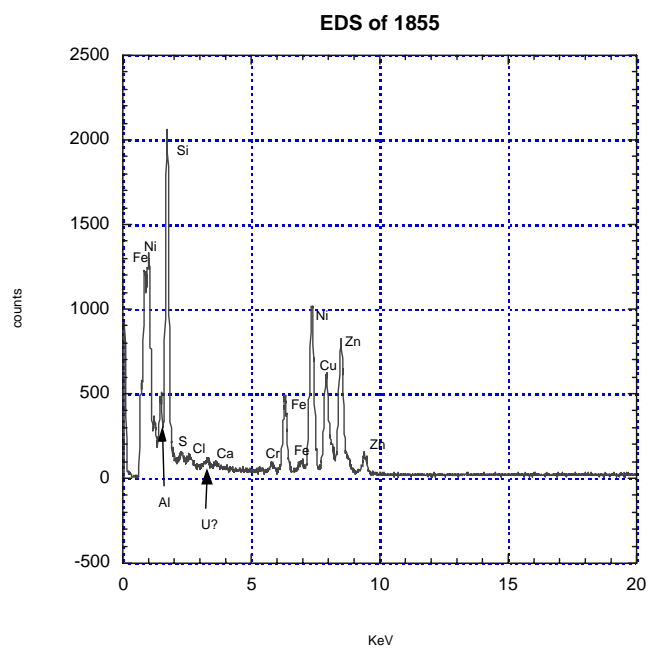

EDS of the Dark Area in CCD 1855

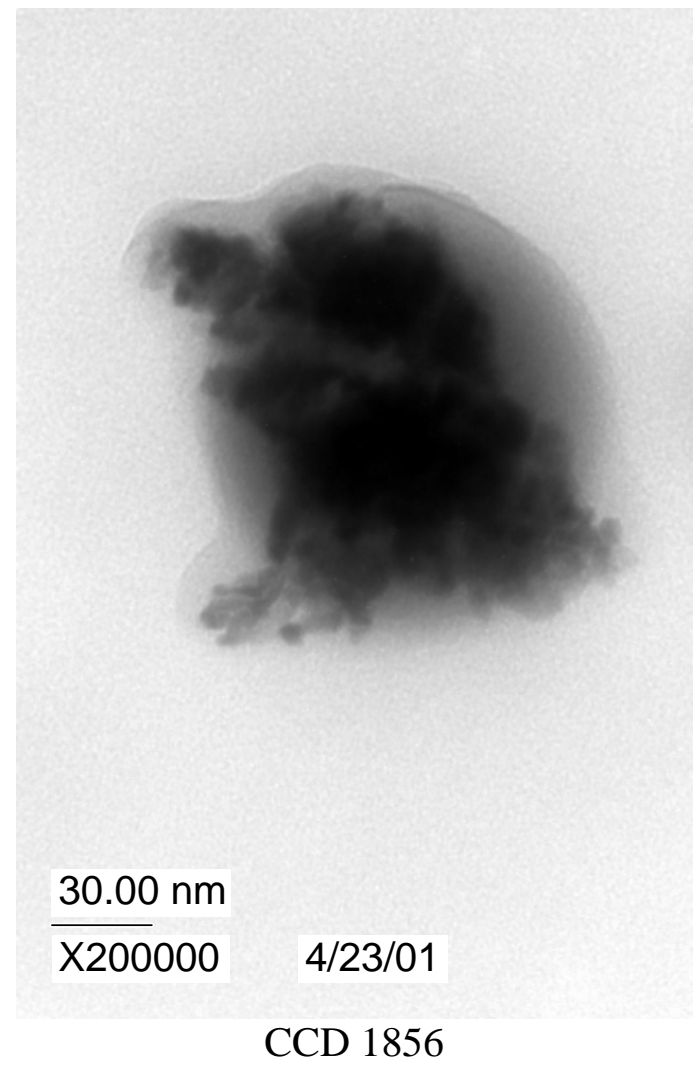

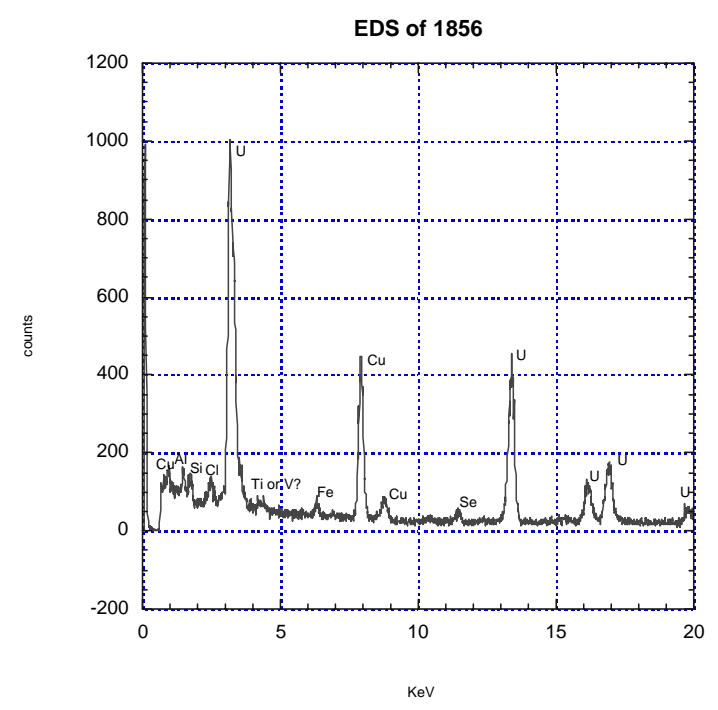

EDS of the Particle in CCD 1856

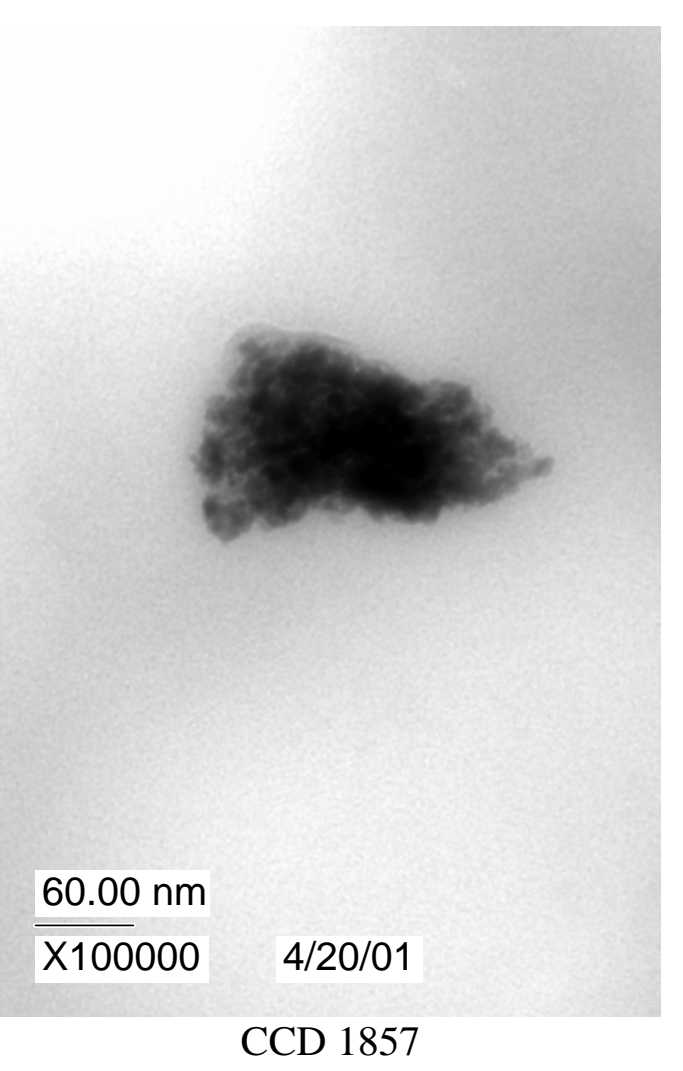




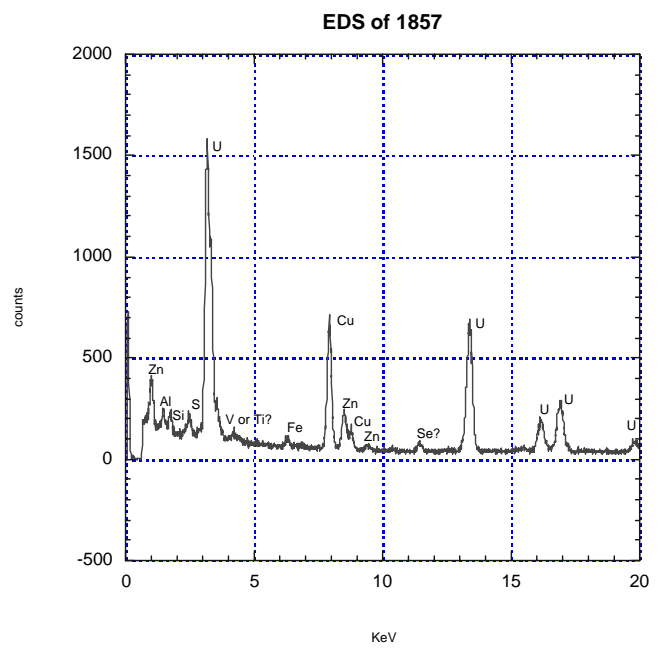

EDS of the Particle in CCD 1857

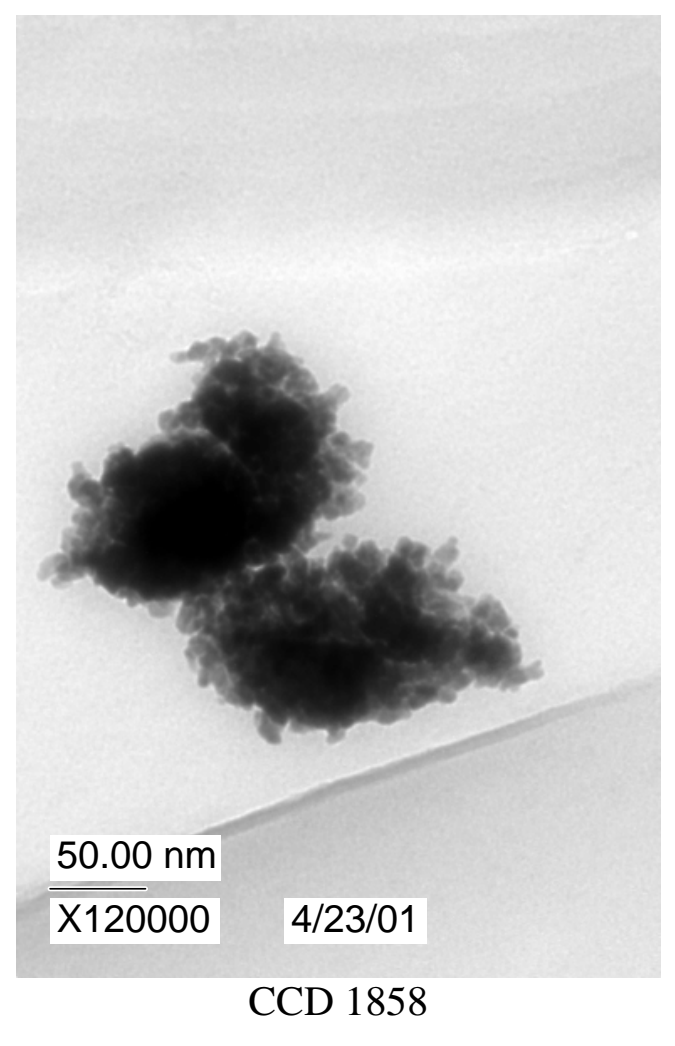

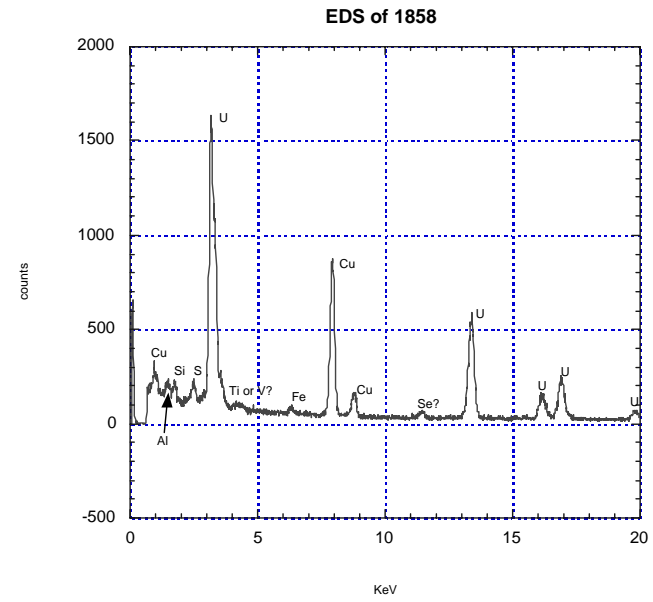

EDS of the Two Particles in CCD 1858

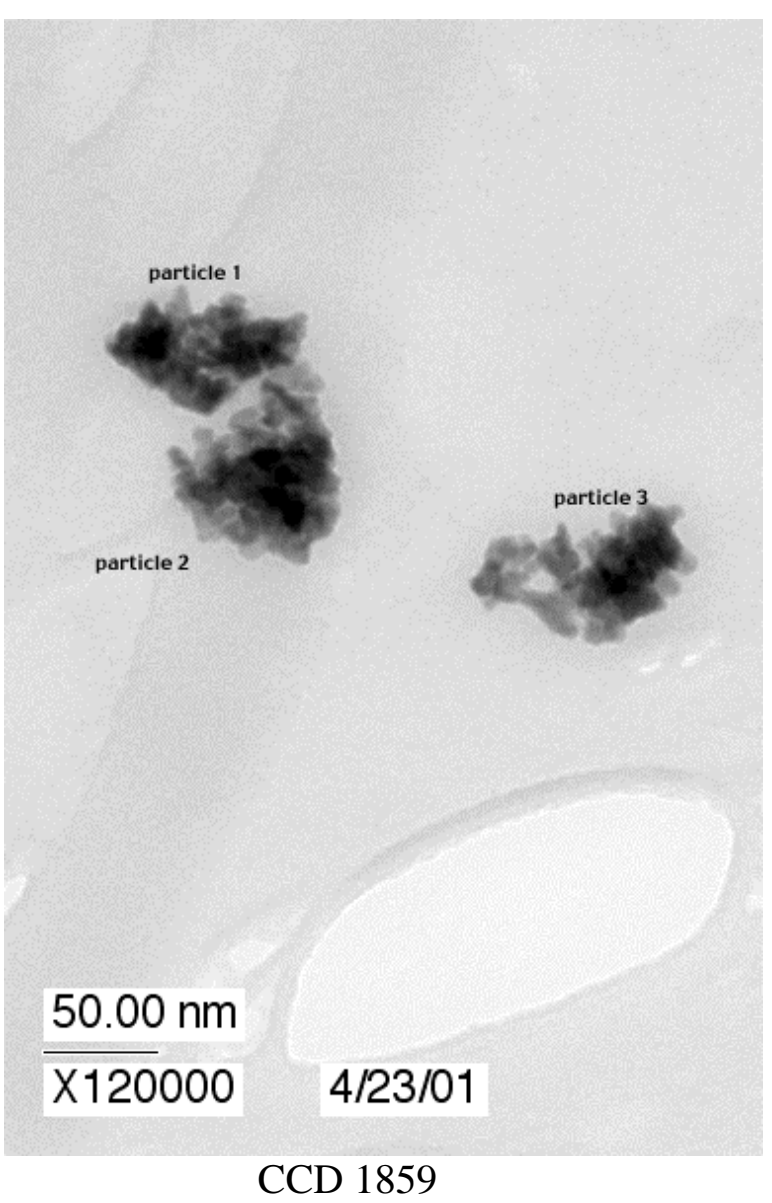




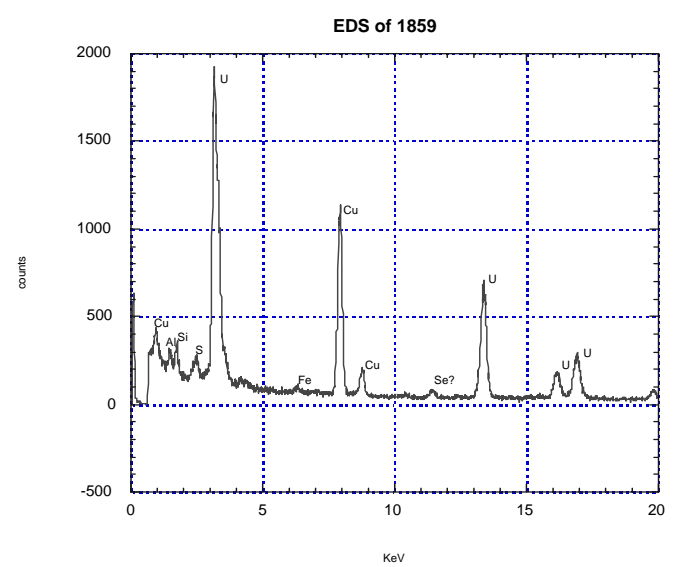

EDS of Particle 1 in CCD 1859

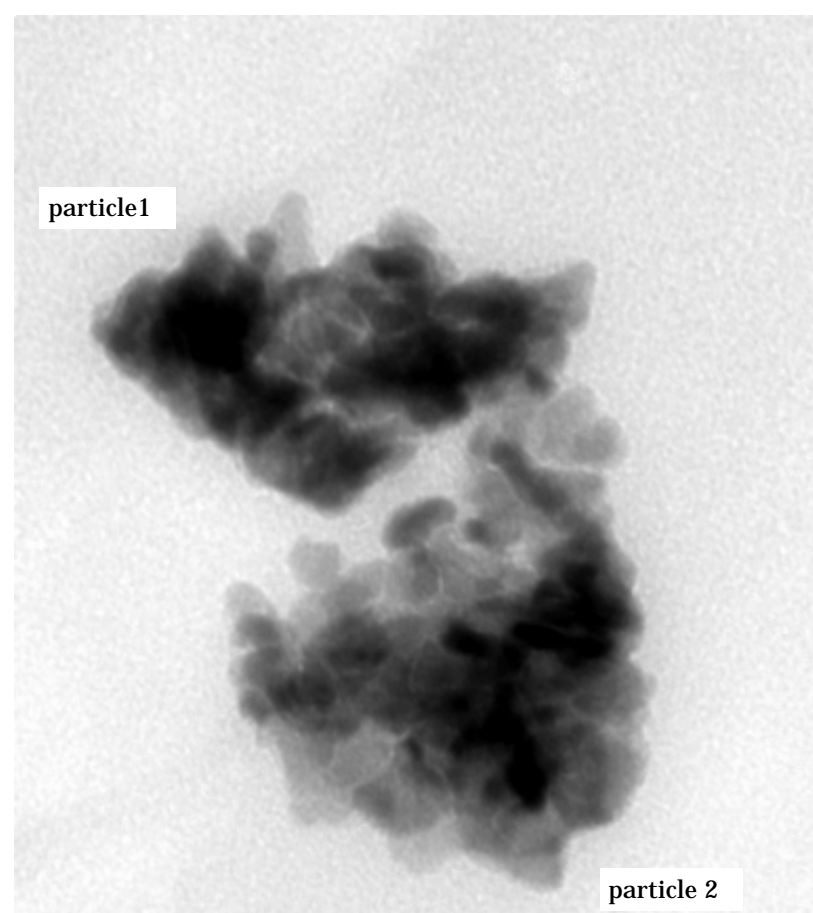

$20.00 \mathrm{~nm}$

X300000 4/23/01

CCD 1860 - This is a high magnification image of particles 1 and 2 from CCD 1859.

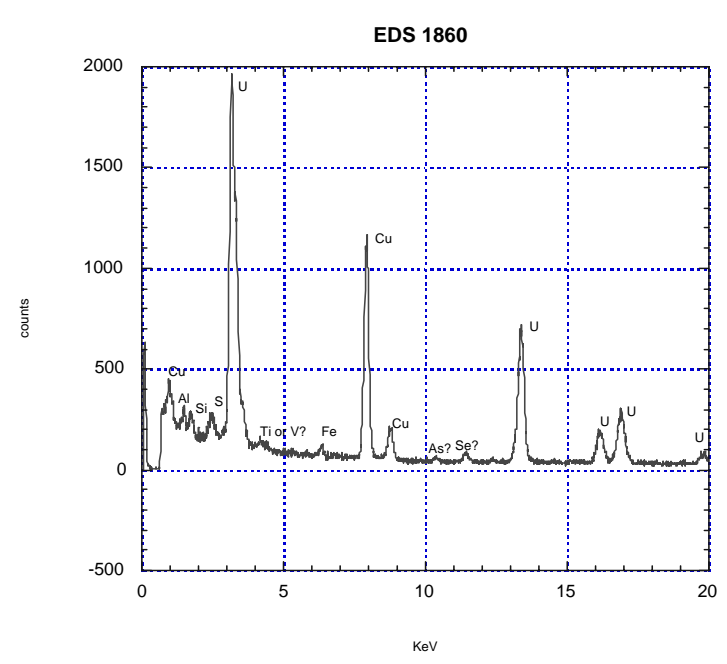

EDS of Particle 2 in CCD 1859 and in CCD 1860

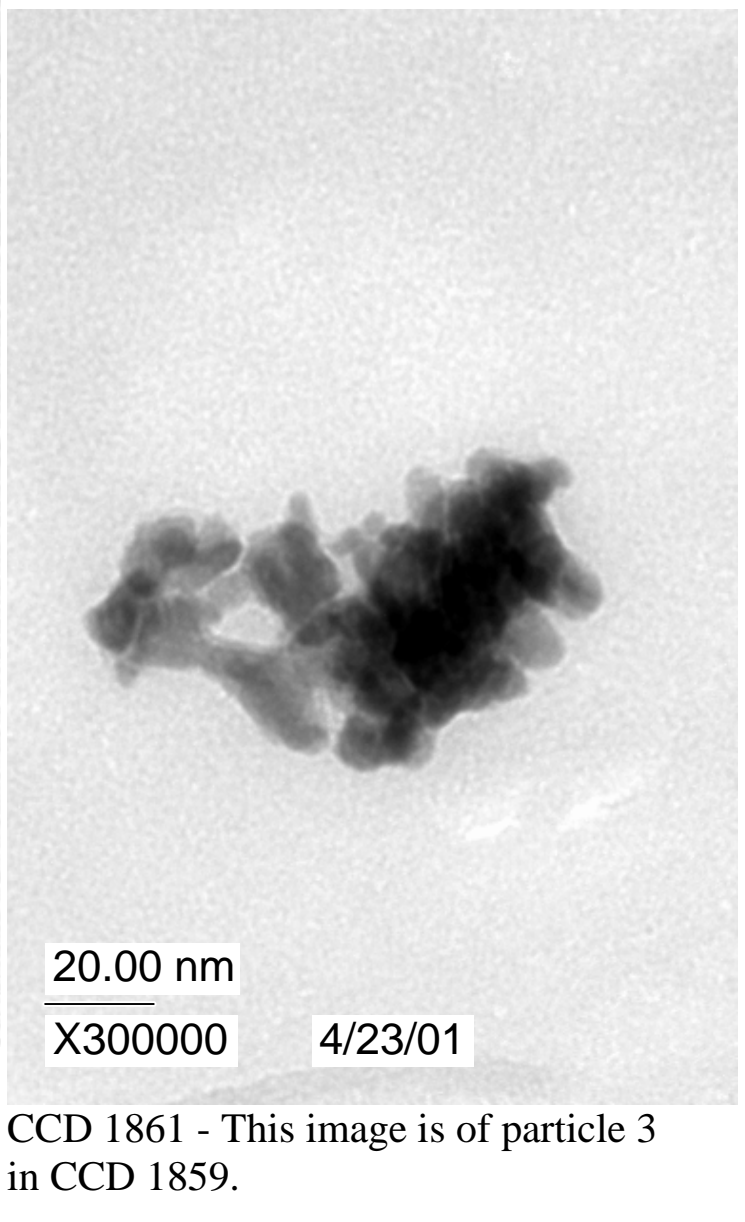




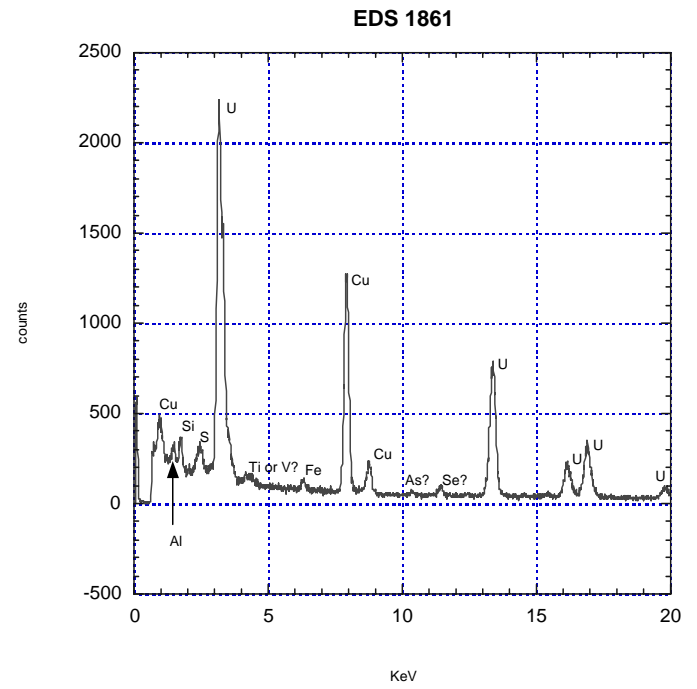

EDS of Particle 3 in CCD 1861 and 1859 
TEM Survey Report for Mike Kaminski

Microscopy Analyst: Jennifer Holly and Jeff Fortner

Sample ID: UUBT2-D108
October 1, 2001

Colloid sample grid \# C 448

This sample was analyzed during the last two weeks of September. This sample is of colloids that have been wicked through a lacey carbon grid. There are 9 images, 1 diffraction pattern and 7 EDS spectra in the pages that follow. The images and spectra acquired are found in the pages that follow. All the copper peaks are artifacts due to the copper grid. A summary table lists the images and the EDS findings. The low magnification images were taken to show relative concentration of particles per grid square. A true analysis of concentration is nearly impossible using a TEM. An approximate analysis of concentration could be obtained with several days of TEM imaging and extrapolation, if necessary.

Table 1. Sample ID: TEM Colloids-Grid CC448, of Sample UUBT2-108 for Mike Kaminski

\begin{tabular}{|c|c|c|c|c|}
\hline Block \# & Grid \# & Notebook Ref. & $\begin{array}{l}\text { Digital Image or } \\
\text { EDS File Numbers }\end{array}$ & $\begin{array}{l}\text { Comments and Elements } \\
\text { Identified by EDS }\end{array}$ \\
\hline NA & $\mathrm{C} 448$ & SN1718: 107 & 2009 & $\begin{array}{l}\text { Large amount of } \mathrm{U} \text { and smaller } \\
\text { amounts of } \mathrm{Al}, \mathrm{Si}, \mathrm{S}, \mathrm{Ni} \text { and } \mathrm{Fe} \text {. }\end{array}$ \\
\hline NA & C448 & SN1718: 107 & 2010 & $\begin{array}{l}\text { NO EDS -This is a low } \\
\text { magnification overview image. }\end{array}$ \\
\hline NA & C448 & SN1718: 107 & 2011 & $\begin{array}{l}\text { NO EDS-This is a low } \\
\text { magnification overview image. }\end{array}$ \\
\hline NA & C448 & SN1718: 107 & 2012 & $\begin{array}{l}\text { Large amount of } \mathrm{U} \text { and smaller } \\
\text { amounts of } \mathrm{Al}, \mathrm{Si}, \mathrm{S}, \mathrm{Ni} \text { and } \mathrm{Fe} \text {. }\end{array}$ \\
\hline NA & C448 & SN1718: 107 & 2013 & $\begin{array}{l}\text { NO EDS - This image is a low } \\
\text { magnification overview. }\end{array}$ \\
\hline NA & C448 & SN1718: 107 & 2014 & $\begin{array}{l}\text { Large amount of } \mathrm{Ti} \text { and smaller } \\
\text { amounts of } \mathrm{Si}, \mathrm{Fe} \text {, and maybe } \\
\text { Co. }\end{array}$ \\
\hline NA & C448 & SN1718: 107 & 2015 & $\begin{array}{l}\text { Large amount of } \mathrm{U} \text { and smaller } \\
\text { amounts of } \mathrm{Al}, \mathrm{Si}, \mathrm{S}, \mathrm{Ni} \text { and } \mathrm{Fe}\end{array}$ \\
\hline NA & C448 & SN1718: 107 & 2016 & $\begin{array}{l}\text { Large amount of } \mathrm{U} \text { and smaller } \\
\text { amounts of } \mathrm{Al}, \mathrm{Si}, \mathrm{S}, \mathrm{Ni} \text { and } \mathrm{Fe}\end{array}$ \\
\hline NA & C448 & $\begin{array}{l}\text { SN1718:107\& } \\
108\end{array}$ & 2017 & $\begin{array}{l}\text { CCD image only. The two EDS } \\
\text { form this image have been } \\
\text { assigned different file numbers. }\end{array}$ \\
\hline NA & C448 & SN1718: 107 & EDS 2018 & $\begin{array}{l}\text { EDS of the light material in CCD } \\
2017\end{array}$ \\
\hline NA & C448 & SN1718: 107 & EDS 2019 & $\begin{array}{l}\text { EDS of the dark material in CCD } \\
\text { 2017. Large amount of } \mathrm{U} \text { and } \\
\text { smaller amounts of } \mathrm{Al}, \mathrm{Si}, \mathrm{S}, \mathrm{Ni} \text {, } \\
\mathrm{Zn} \text { and } \mathrm{Fe} \text {. }\end{array}$ \\
\hline NA & C448 & SN1718: 107 & $\begin{array}{l}2020 \text { diffraction } \\
\text { composite }\end{array}$ & $\begin{array}{l}\text { Diffraction of dark material in } \\
\text { CCD } 2017 .\end{array}$ \\
\hline
\end{tabular}



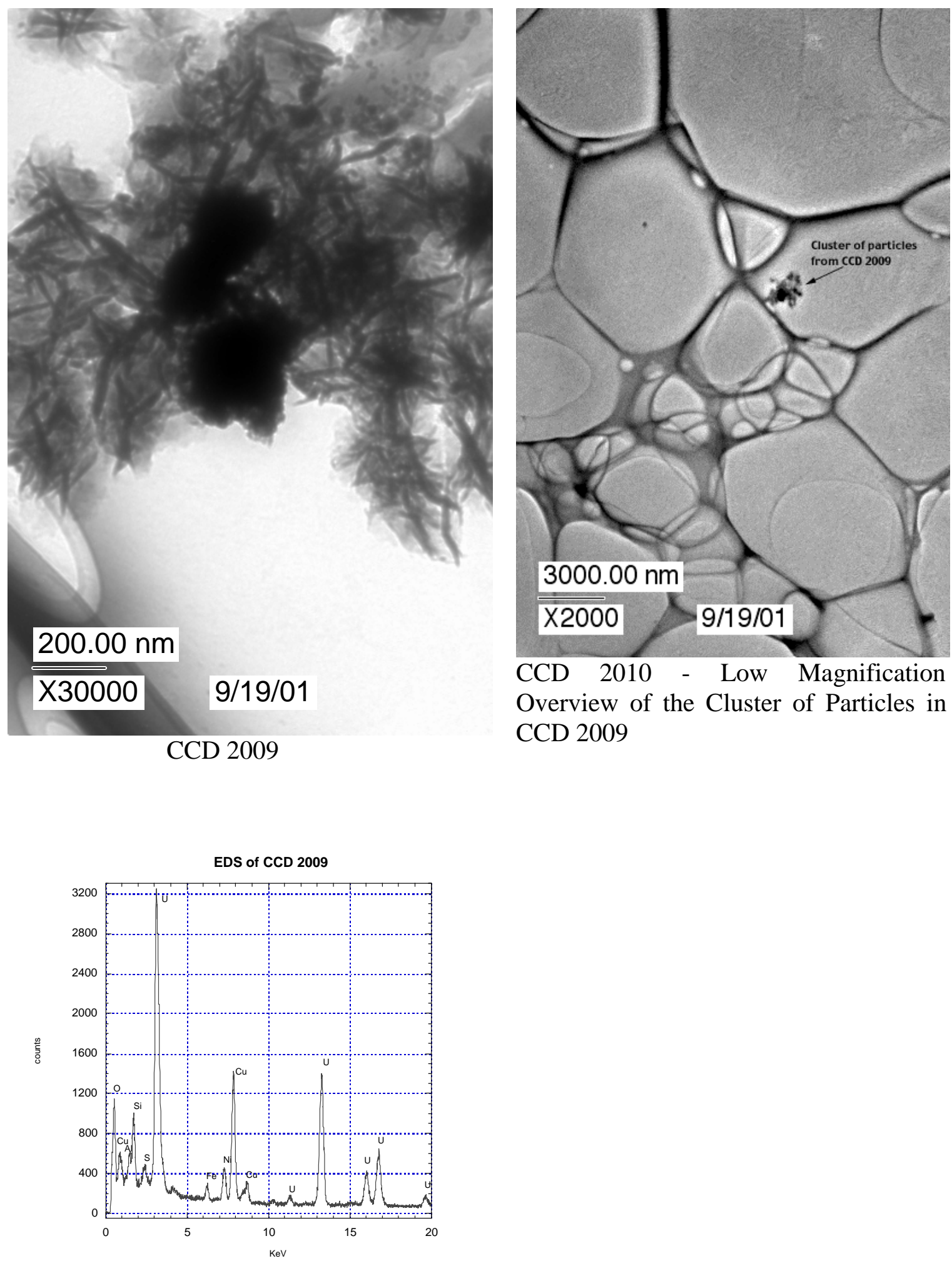

EDS of the Dark Particles in the Center of CCD 2009 


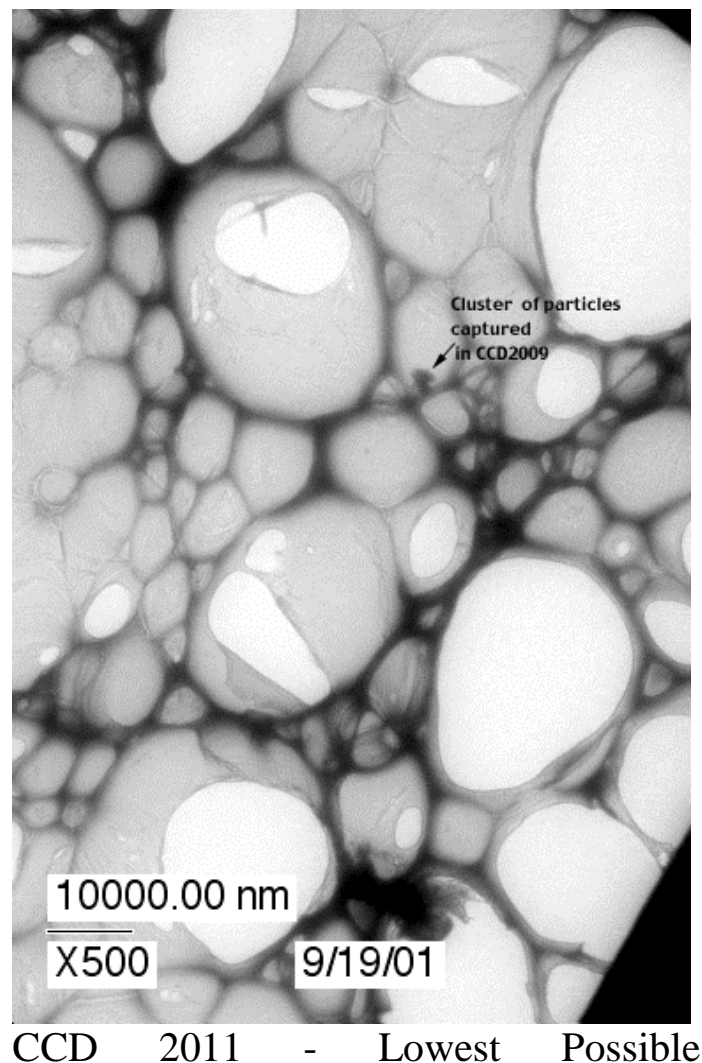

Magnification Image Where the Particles Captured in CCD 2009 Still Remain Visible
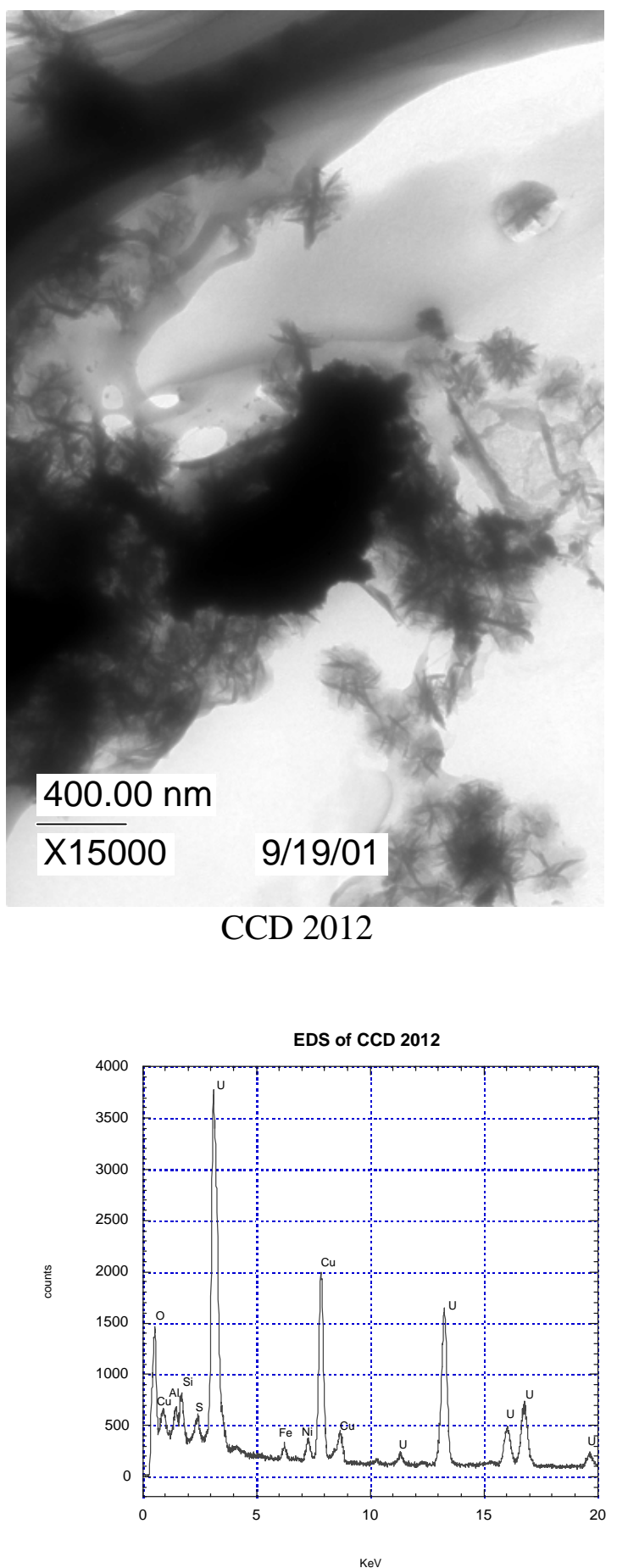

EDS of the Dark Particle in the Center of CCD 2012 


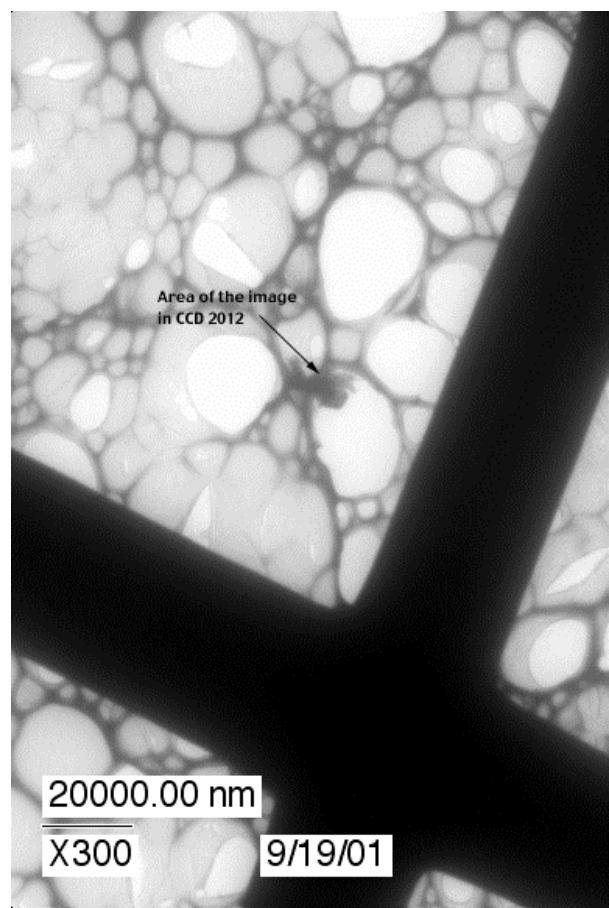

CCD 2013 - Low Magnification Overview of the Area Where CCD 2012 Was Captured

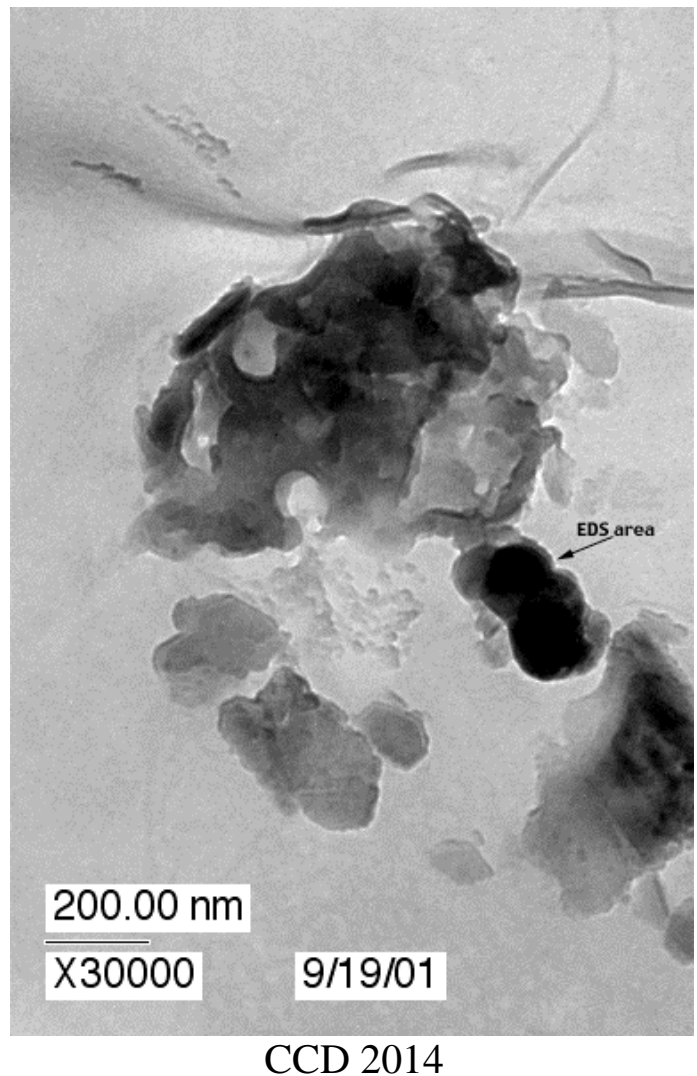

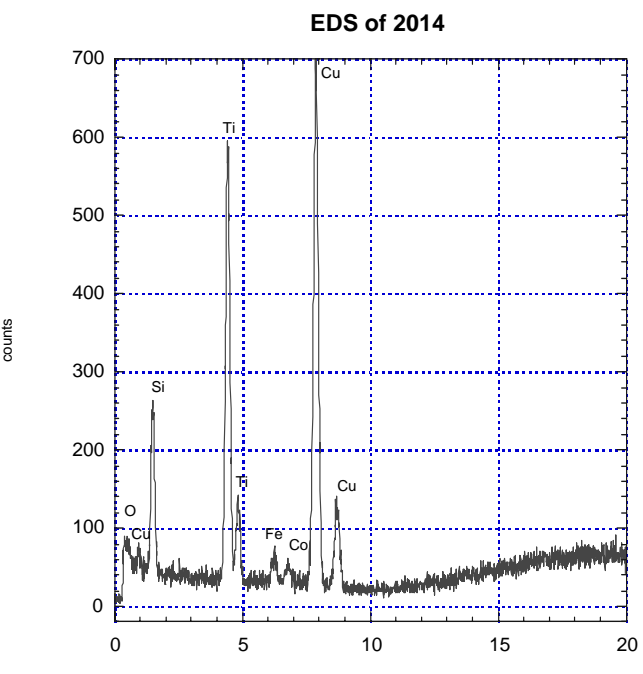

$\mathrm{KeV}$

EDS of the Indicated Area in CCD 2014

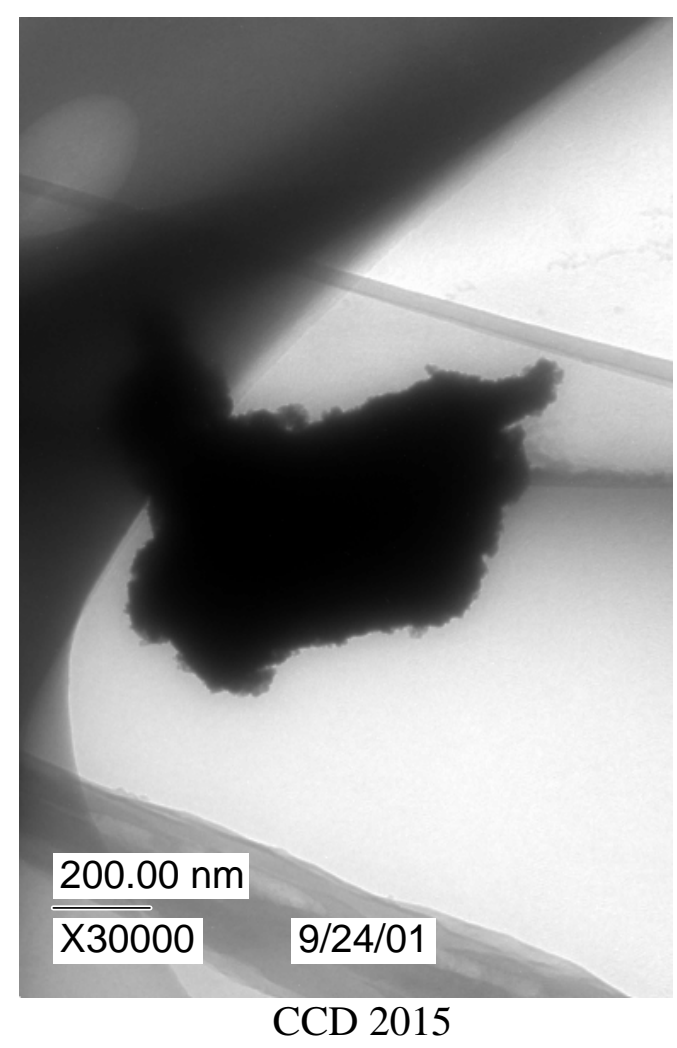




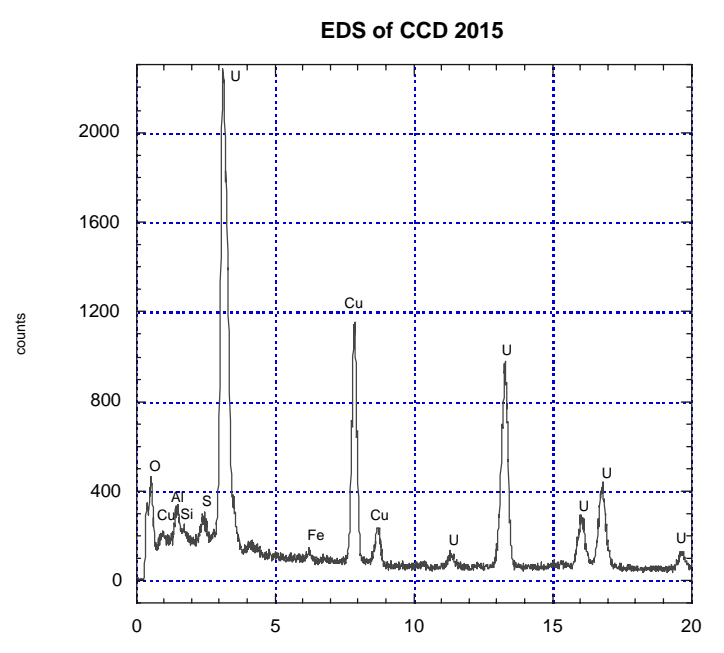

$\mathrm{KeV}$

EDS of the Indicated Area in CCD 2015

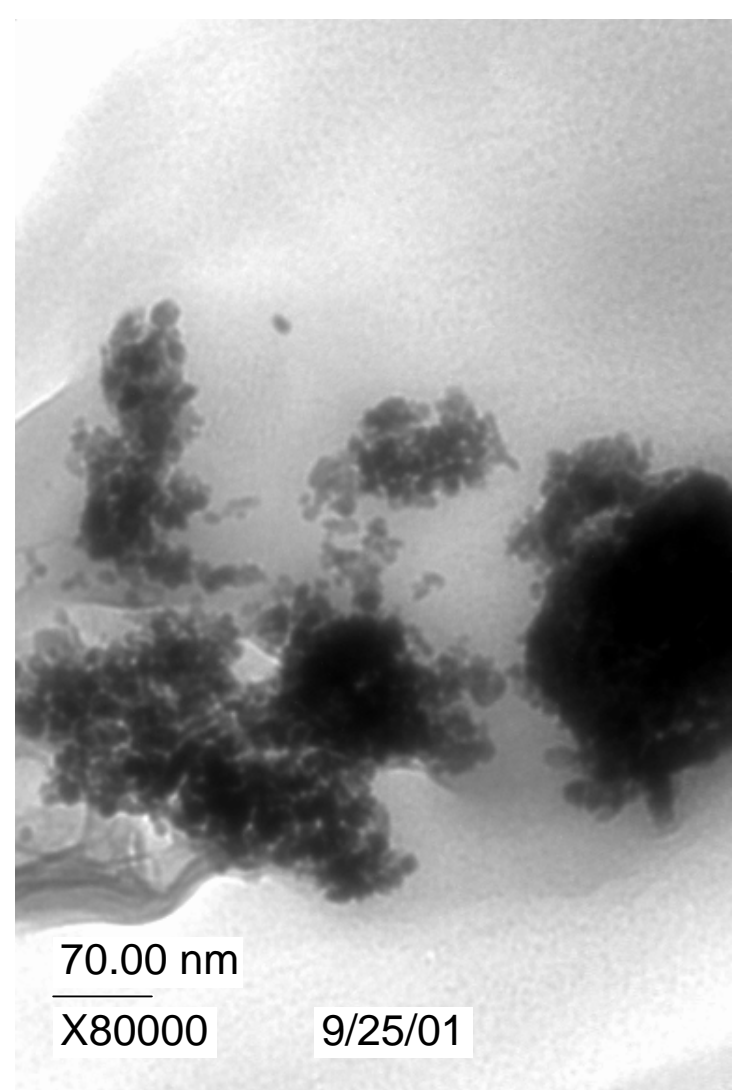

CCD 2016 - Unfortunately, this area became unstable in the beam and the carbon film ripped before I was able to obtain a diffraction pattern.

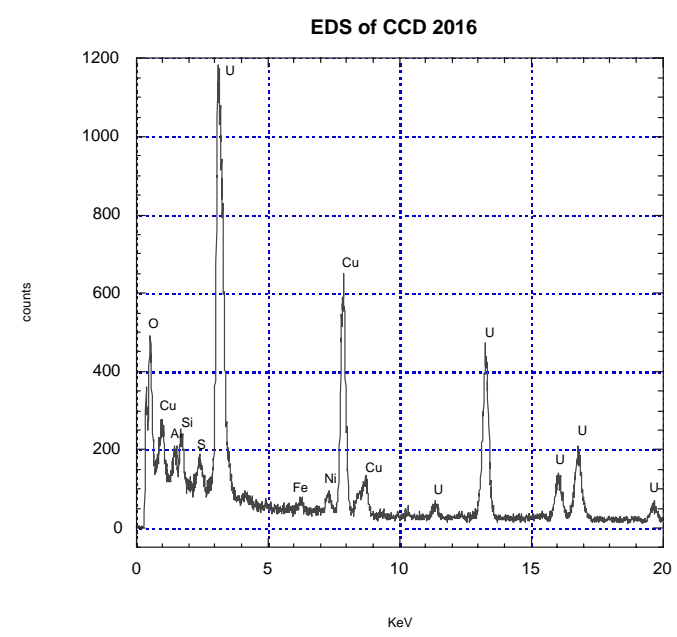

EDS of the Dark Particle in the Center of CCD 2016

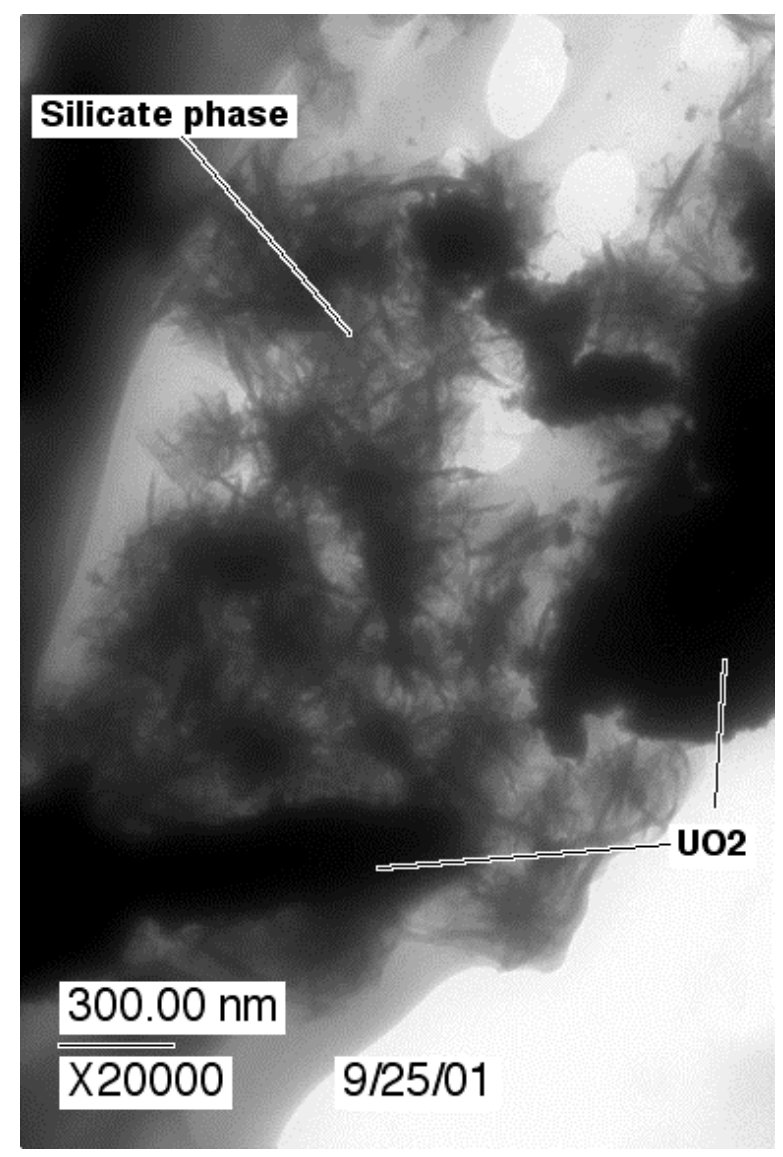

CCD 2017 - This image has two corresponding EDS spectra. EDS 2018 is of the $\mathrm{UO}_{2}$ and EDS 2019 is of the silicate material. The diffraction pattern 2020 is of the dark material labeled as $\mathrm{UO}_{2}$. 


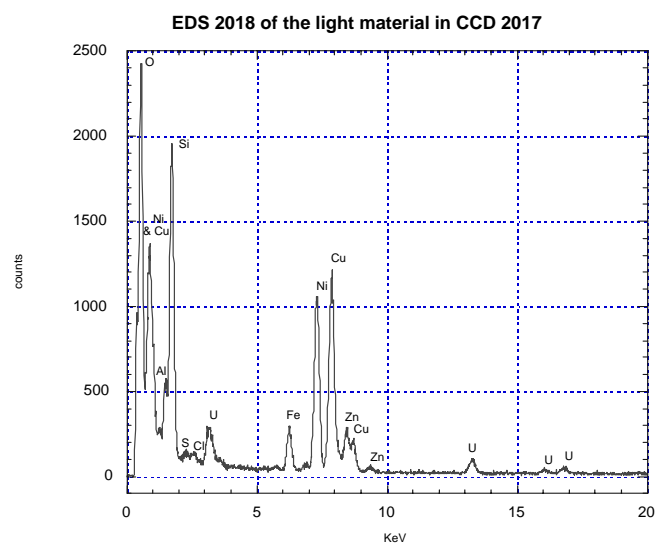

EDS of the Lighter Material (Labeled as Silicate) in CCD 2017

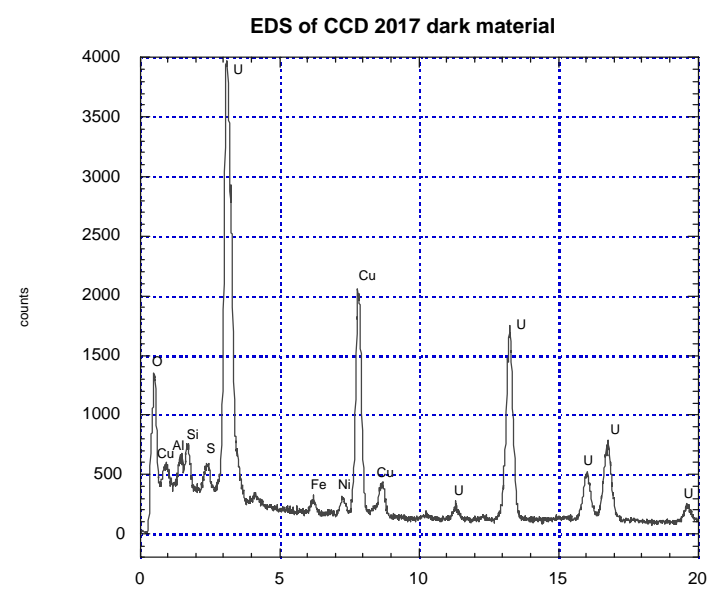

Diffraction 2020 - This composite diffraction pattern is from the dark material in CCD 2017 (labeled as $\mathrm{UO}_{2}$ ) See diffraction analysis on the following page.

EDS of the Dark Material in CCD 2017

(Labeled as $\mathrm{UO}_{2}$ ) in the Image 
Diffraction Image 2020-Composite $(\mathrm{R}=100 \mathrm{~cm})^{\mathrm{a}}$

\begin{tabular}{cccccc}
\hline & & & & $\mathrm{UO}_{2}$ & $\mathrm{UO}_{1.96}$ \\
Pixels & $\mathrm{Q}(1 / \AA)$ & d-spacing $(\AA)$ & error $( \pm \AA)$ & 78-0725) & $\begin{array}{c}\text { 75-0413) } \\
\text { (JCPDS-ICDD }\end{array}$ \\
\hline 49 & 1.328 & 4.732 & \pm 0.09 & & \\
72 & 1.951 & 3.220 & \pm 0.04 & 3.155 & 3.159 \\
88 & 2.385 & 2.635 & \pm 0.03 & 2.733 & 2.736 \\
119 & 3.225 & 1.948 & \pm 0.02 & 1.933 & 1.935 \\
138 & 3.740 & 1.680 & \pm 0.01 & 1.680 & 1.65 \\
151 & 4.092 & 1.535 & \pm 0.01 & 1.578 & 1.58 \\
\hline
\end{tabular}

${ }^{\mathrm{a}}$ Likely sub-stoichiometric $\mathrm{UO}_{2}$. 
TEM Survey Report for Mike Kaminski

Microscopy Analyst: Jennifer Holly

Sample ID: UUBT2-D115
July 2, 2001

Colloid Sample Grid \# C 433

This sample was analyzed during the second week of June. There are 9 images and 8 EDS spectra in the pages that follow. The particles appear to be as small as $5 \mathrm{~nm}$. Some particles are clustered into masses ranging in size from $1500 \mathrm{~nm}$ down to $90 \mathrm{~nm}$. The images and spectra acquired are found in the pages that follow. All the copper peaks are artifacts due to the copper grid. A summary table lists the images and the EDS findings.

Table 1. Sample ID: UUBT2-D115 for Mike Kaminski

\begin{tabular}{|c|c|c|c|c|}
\hline Block \# & Grid \# & Notebook Ref. & $\begin{array}{l}\text { Digital Image } \\
\text { Nos. }\end{array}$ & $\begin{array}{l}\text { Comments and Elements } \\
\text { Identified by EDS }\end{array}$ \\
\hline NA & $\mathrm{C} 433$ & SN1718:89 & 1930 & $\begin{array}{l}\text { Large amounts of } \mathrm{Si} \text {, and } \mathrm{Ni} \text { with } \\
\text { smaller amount of } \mathrm{Al}, \mathrm{S}, \mathrm{Cl}, \mathrm{Ca} \text {, } \\
\mathrm{U}, \mathrm{Fe} \text {, and } \mathrm{Zn} \text {. }\end{array}$ \\
\hline NA & C433 & SN1718:89 & 1931 & $\begin{array}{l}\text { Large amounts of } \mathrm{Si} \text {, and } \mathrm{Ni} \text { with } \\
\text { smaller amount of } \mathrm{Al}, \mathrm{S}, \mathrm{Cl}, \mathrm{Ca} \text {, } \\
\mathrm{U}, \mathrm{Fe} \text {, and } \mathrm{Zn} \text {. }\end{array}$ \\
\hline NA & C433 & SN1718:89 & 1932 & Ca-rich material. \\
\hline NA & $\mathrm{C} 433$ & SN1718:89 & 1933 & $\begin{array}{l}\text { A low magnification overview } \\
\text { image of the area in CCD } \\
1934,1935 \text {, and } 1936 . \text { No EDS } \\
\text { was performed. }\end{array}$ \\
\hline NA & C433 & SN1718:89 & 1934 & $\begin{array}{l}\text { A high magnification image of } \\
\text { the light round material in CCD } \\
\text { 1933. EDS results: Large } \\
\text { amount of } \mathrm{Ca} \text { and smaller amount } \\
\text { of } \mathrm{Mg}, \mathrm{Si}, \mathrm{S} \text { and } \mathrm{U} \text {. }\end{array}$ \\
\hline NA & C433 & SN1718:89 & 1935 & $\begin{array}{l}\text { Large amount of } \mathrm{U} \text { and smaller } \\
\text { amounts of } \mathrm{Cl}, \mathrm{Si}, \mathrm{Al} \text {, and } \mathrm{S} \text {. }\end{array}$ \\
\hline NA & $\mathrm{C} 433$ & SN1718:89 & 1936 & $\begin{array}{l}\text { Large amounts of } \mathrm{Si} \text {, and } \mathrm{Ni} \text { with } \\
\text { smaller amount of } \mathrm{Al}, \mathrm{S}, \mathrm{Cl}, \mathrm{Ca} \text {, } \\
\mathrm{U}, \mathrm{Fe} \text {, and } \mathrm{Zn} \text {. }\end{array}$ \\
\hline NA & C433 & SN1718:90 & 1937 & $\begin{array}{l}\text { Large amount of } \mathrm{U} \text { and smaller } \\
\text { amounts of } \mathrm{O}, \mathrm{Si}, \mathrm{Al} \text {, and } \mathrm{S} \text {. }\end{array}$ \\
\hline NA & C433 & SN1718:90 & 1938 & $\begin{array}{l}\text { Large amount of } \mathrm{U} \text { and smaller } \\
\text { amounts of } \mathrm{O}, \mathrm{Si}, \mathrm{Al}, \mathrm{Fe} \text {, and } \mathrm{S} \text {. }\end{array}$ \\
\hline NA & C433 & SN1718:90 & 1956 & $\begin{array}{l}\text { Large amount of } \mathrm{U} \text { and smaller } \\
\text { amounts of } \mathrm{O}, \mathrm{Si} \text {, and } \mathrm{Al} \text {. } \\
\text { Unfortunately, this particle was } \\
\text { too thick for diffraction. }\end{array}$ \\
\hline
\end{tabular}


Table 1. Cont.

\begin{tabular}{|c|c|c|c|c|}
\hline Block \# & Grid \# & Notebook Ref. & $\begin{array}{l}\text { Digital Image } \\
\text { Nos. }\end{array}$ & $\begin{array}{l}\text { Comments and Elements } \\
\text { Identified by EDS }\end{array}$ \\
\hline NA & C433 & SN1718:93 & $\begin{array}{l}1957 \\
1957 \text { diff } \\
1957 \text { center spot }\end{array}$ & $\begin{array}{l}\text { Large amount of } \mathrm{U} \text { and smaller } \\
\text { amounts of } \mathrm{O}, \mathrm{Si} \text {, and } \mathrm{Al} \text {. The } 2 \\
\text { additional files are diffraction } \\
\text { patterns. Diffraction data } \\
\text { suggests the particles are } \mathrm{UO}_{2} \text {. }\end{array}$ \\
\hline NA & C433 & SN1718:93 & $\begin{array}{l}1958 \\
1958 \text { diff } \\
1958 \text { center spot } \\
1958 \text { combined }\end{array}$ & $\begin{array}{l}\text { The diffraction data has been } \\
\text { discarded due to using a camera } \\
\text { length and exposure time that } \\
\text { were too short. EDS shows a } \\
\text { large amount of U \& Si. }\end{array}$ \\
\hline NA & C433 & SN1718:93 & $\begin{array}{l}1959 \\
1959 \text { diff } \\
1959 \text { center spot } \\
1959 \text { combined }\end{array}$ & $\begin{array}{l}\text { Large amount of } \mathrm{U} \text { and smaller } \\
\text { amounts of } \mathrm{O}, \mathrm{Cl} \text {, and } \mathrm{Si} \text {. The } \\
\text { additional } 3 \text { files are diffraction } \\
\text { patterns. Diffraction data } \\
\text { suggests the particles are } \mathrm{UO}_{2} \text {. }\end{array}$ \\
\hline
\end{tabular}



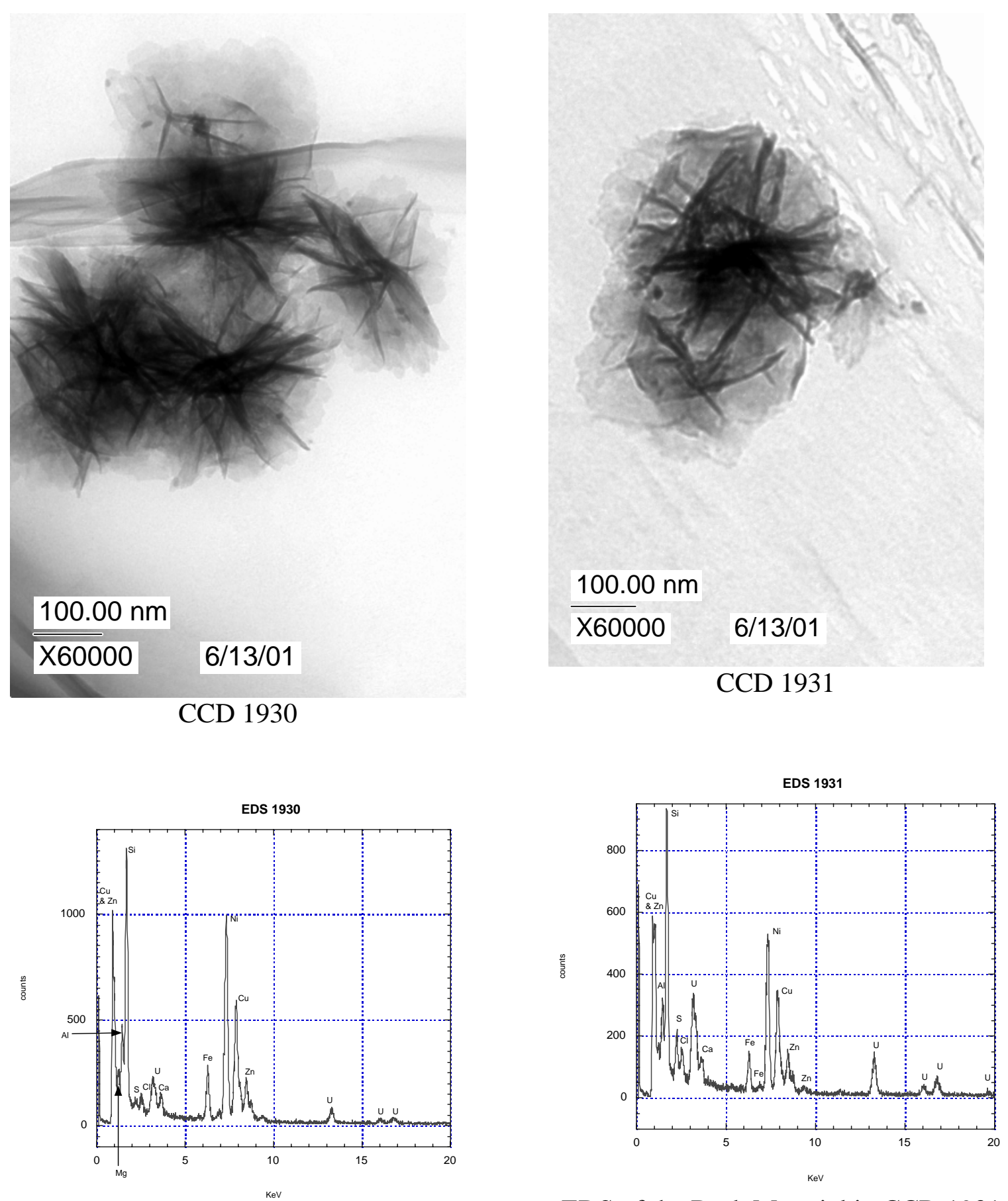

EDS of the Dark Material in CCD 1930

EDS of the Dark Material in CCD 1931 

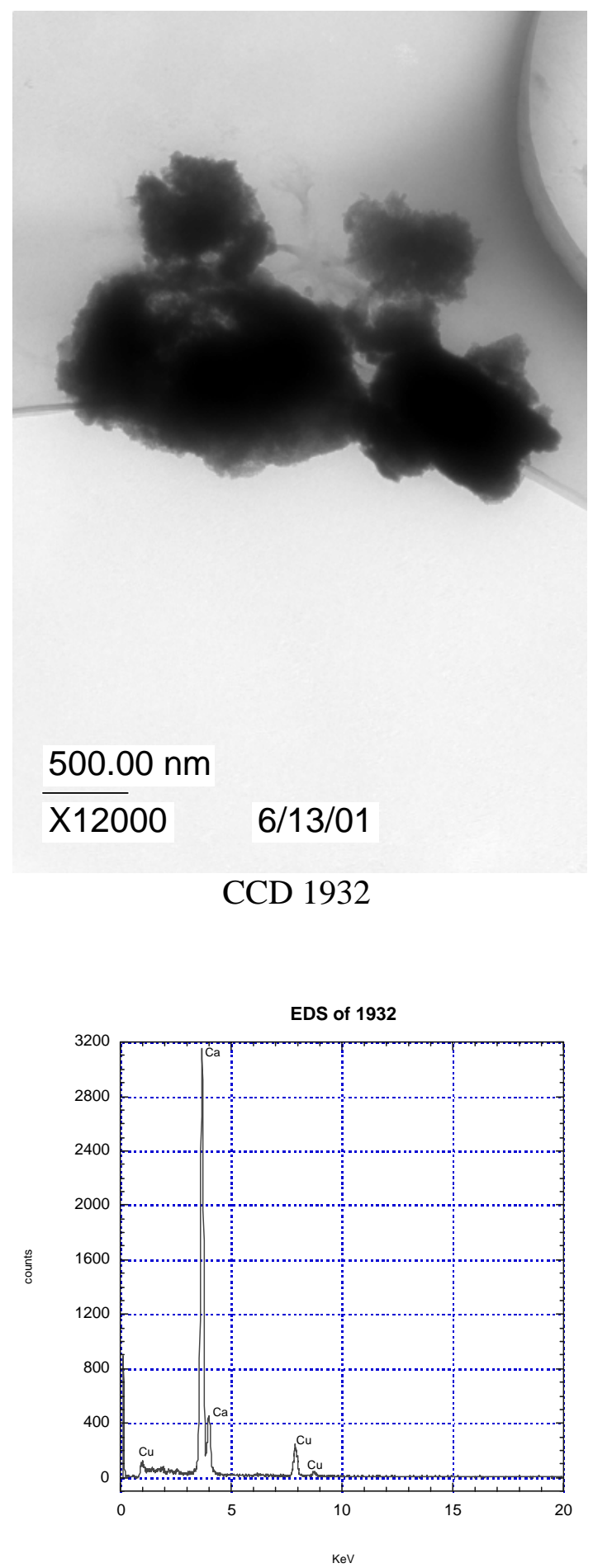

EDS of the Dark Particle in CCD 1932

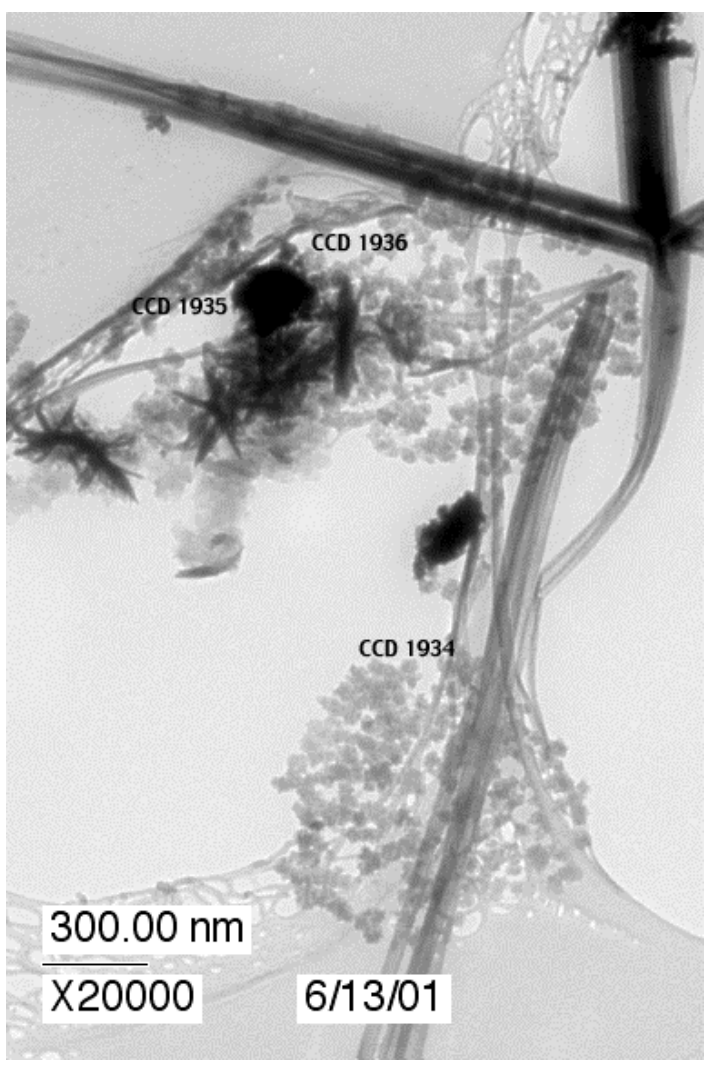

CCD 1933 - This is a low magnification overview image of the areas in CCD 1934, 1935 and 1936. 


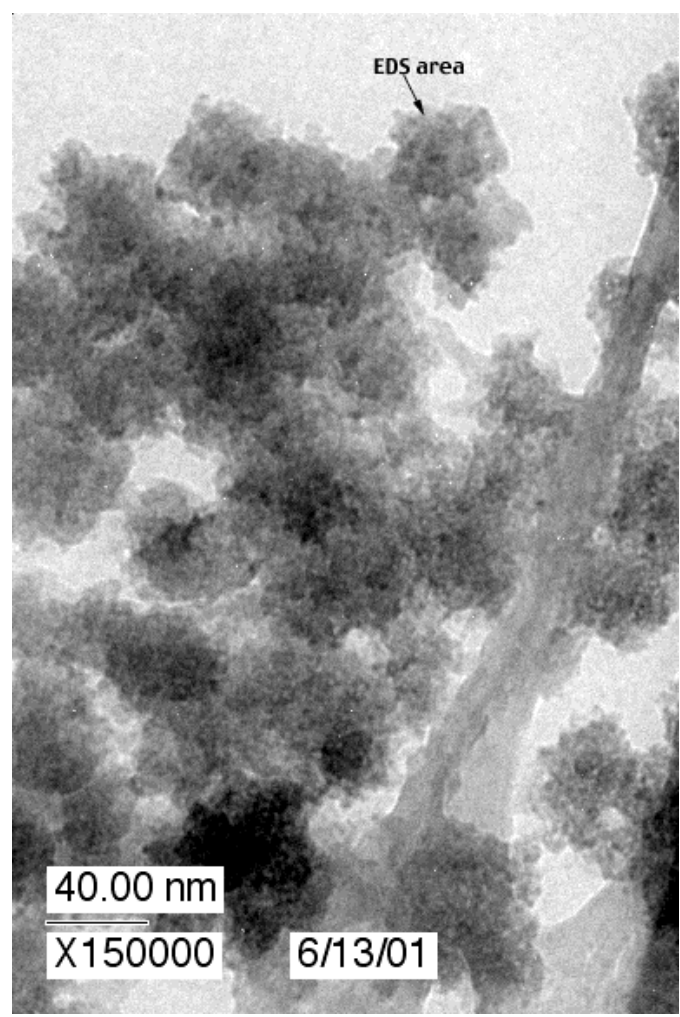

CCD 1934 - A High Magnification Image of the Indicated Area (the Light Round Material) in CCD 1933

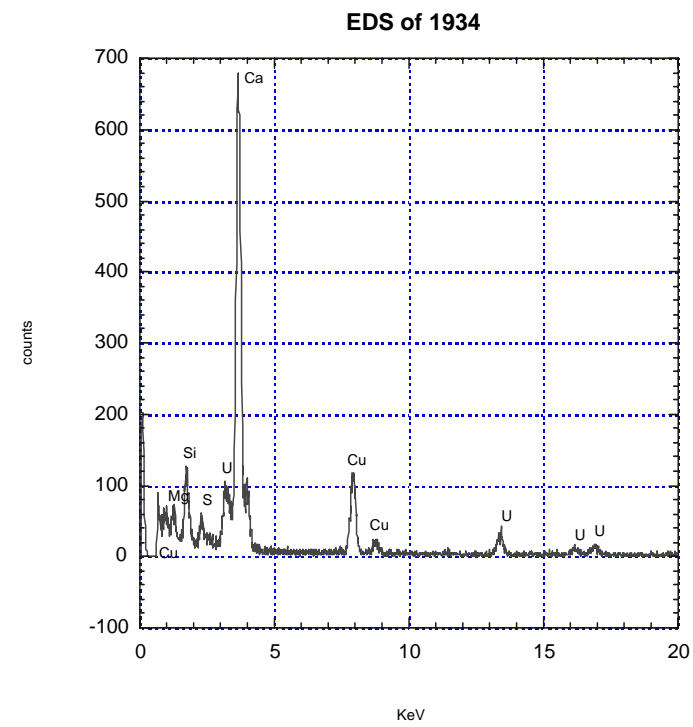

EDS of the Indicated Round Material in CCD 1934

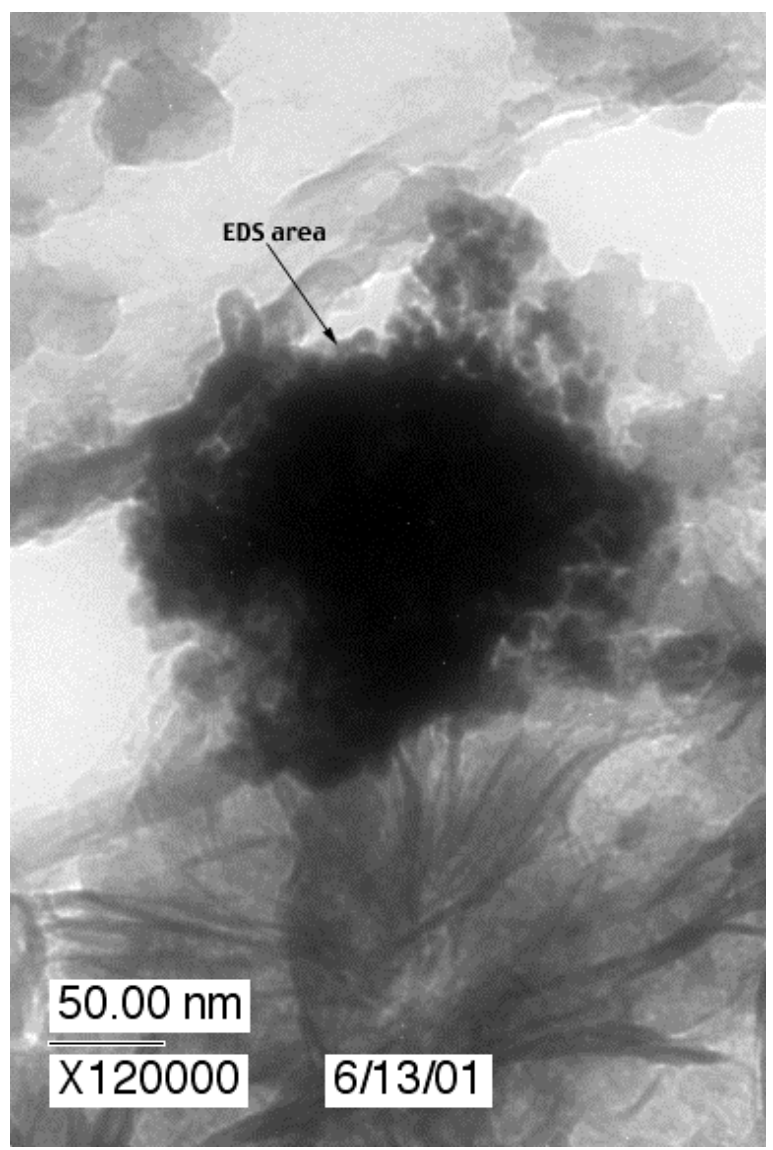

CCD1935 - A High Magnification Image of the Indicated Area (Dark Material) in CCD 1933

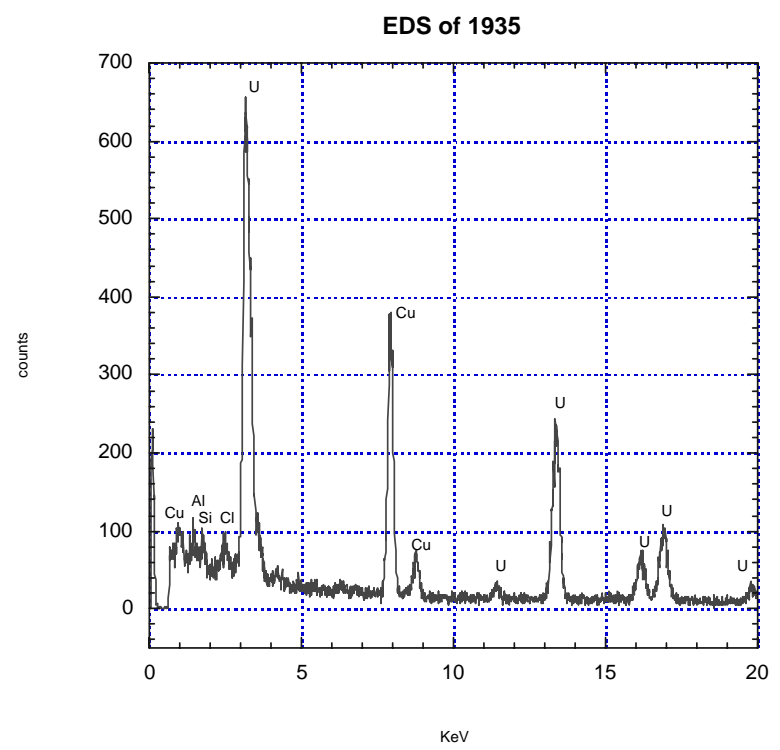

EDS of the Indicated Area in CCD 1935 (the Darkest Material) 


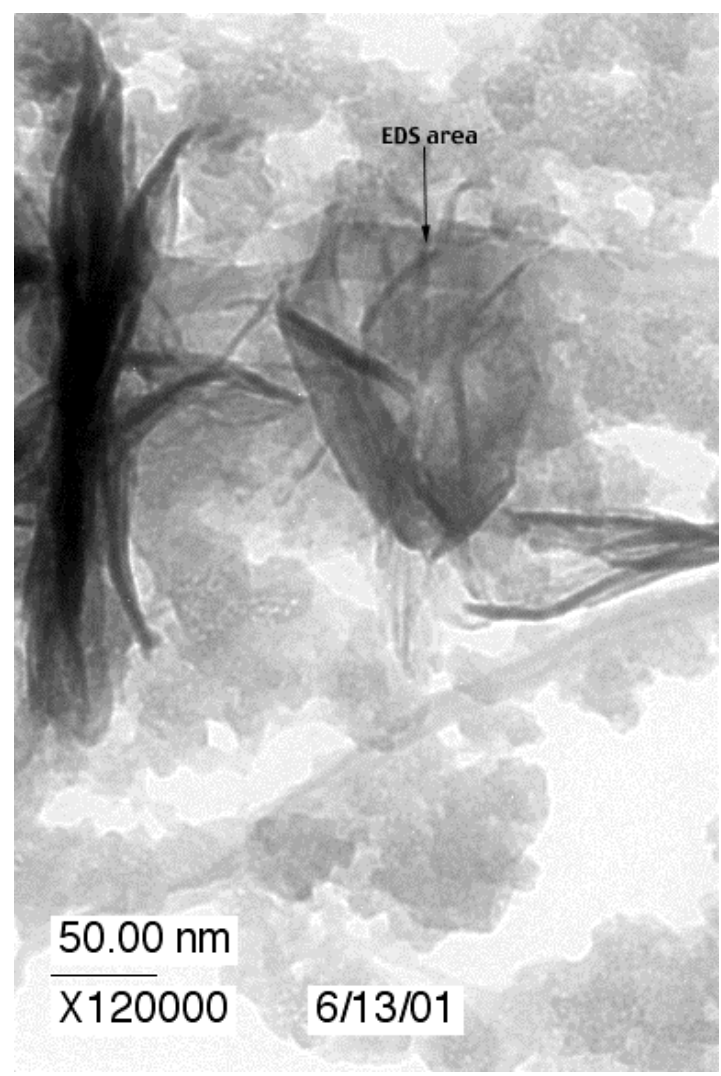

CCD 1936 - A High Magnification Image of the Indicated Area in CCD 1933

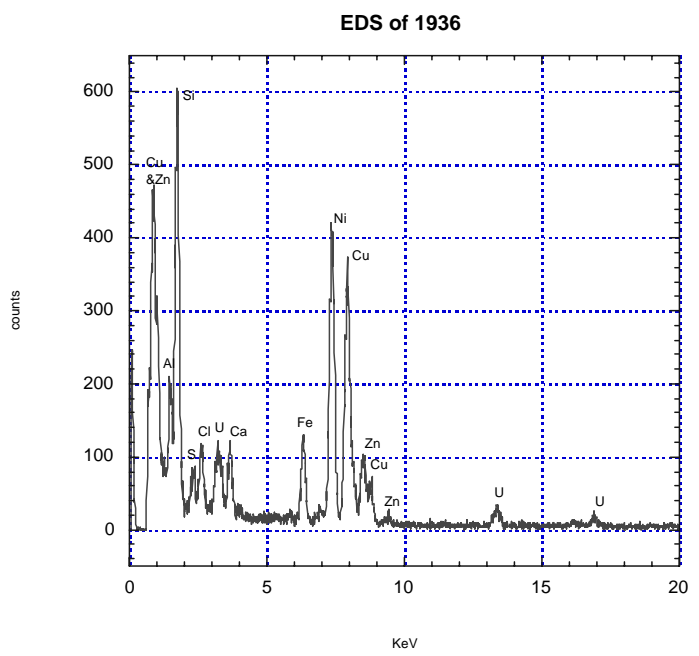

EDS of the Indicated Area in CCD 1936

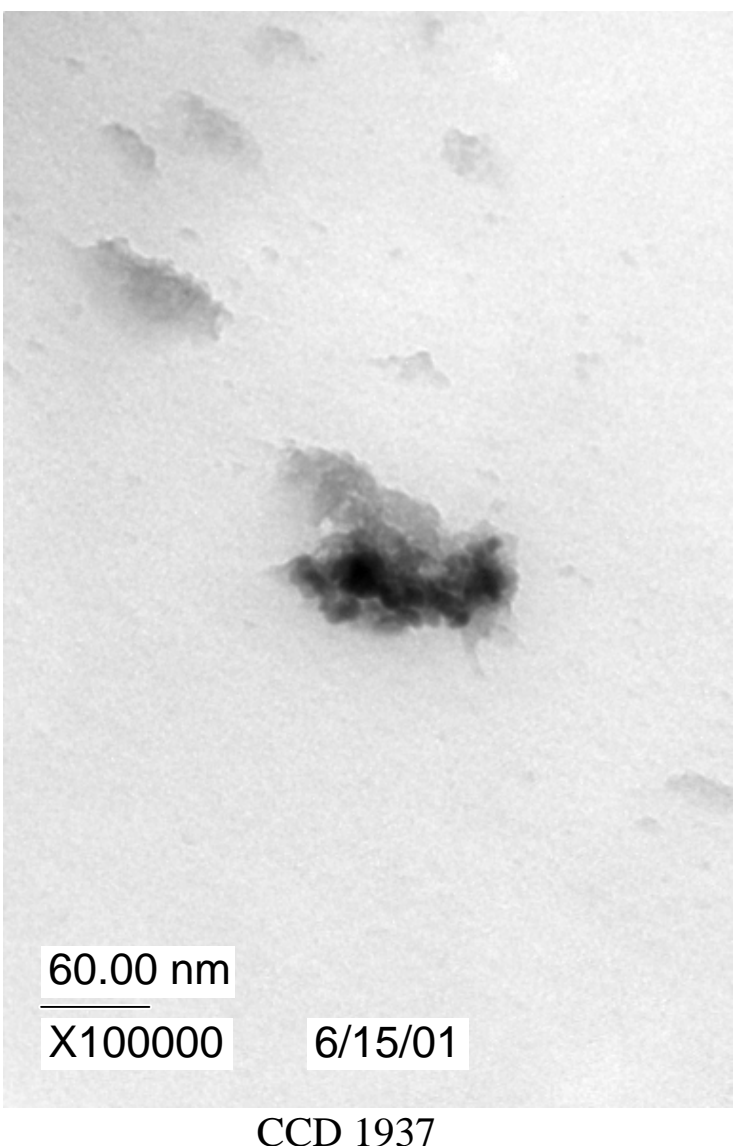

CCD 1937

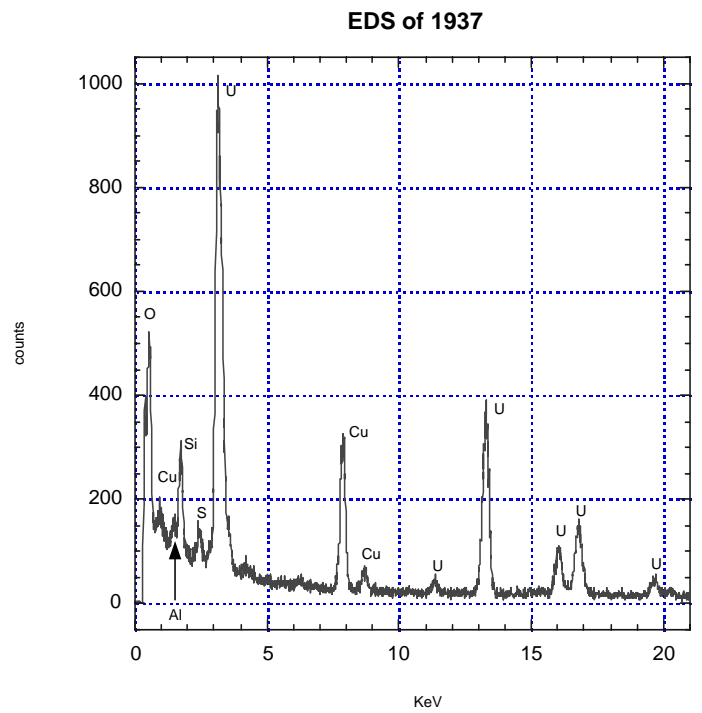

EDS of the Dark Material in the Center of CCD 1937 


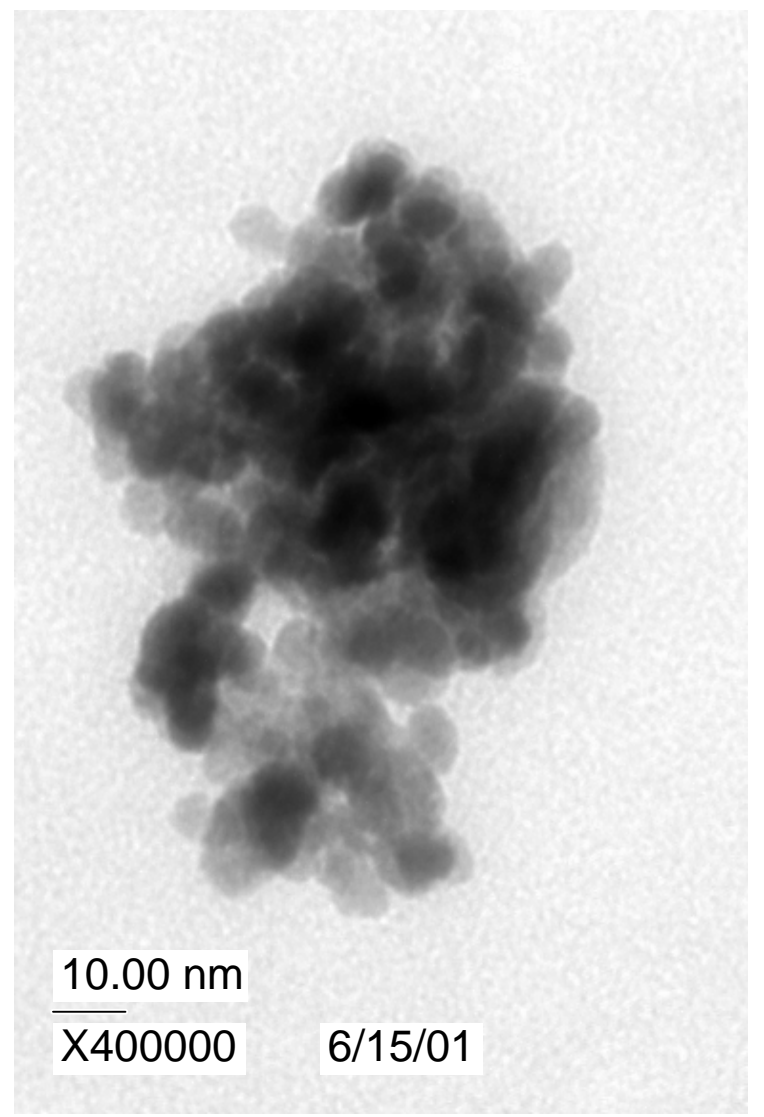

CCD 1938 - High Magnification Image Showing a Cluster of Particles in the 5$10 \mathrm{~nm}$ Size Range

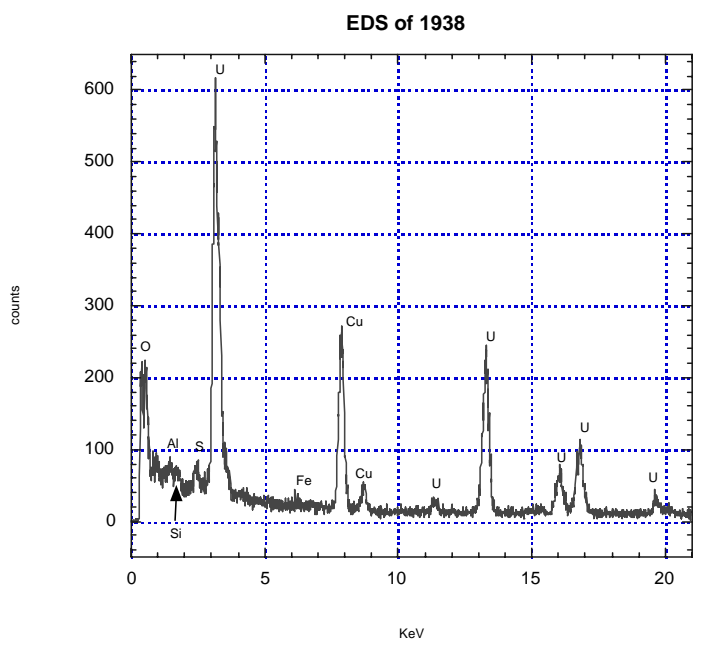

EDS of the Dark Round Material in CCD 1938
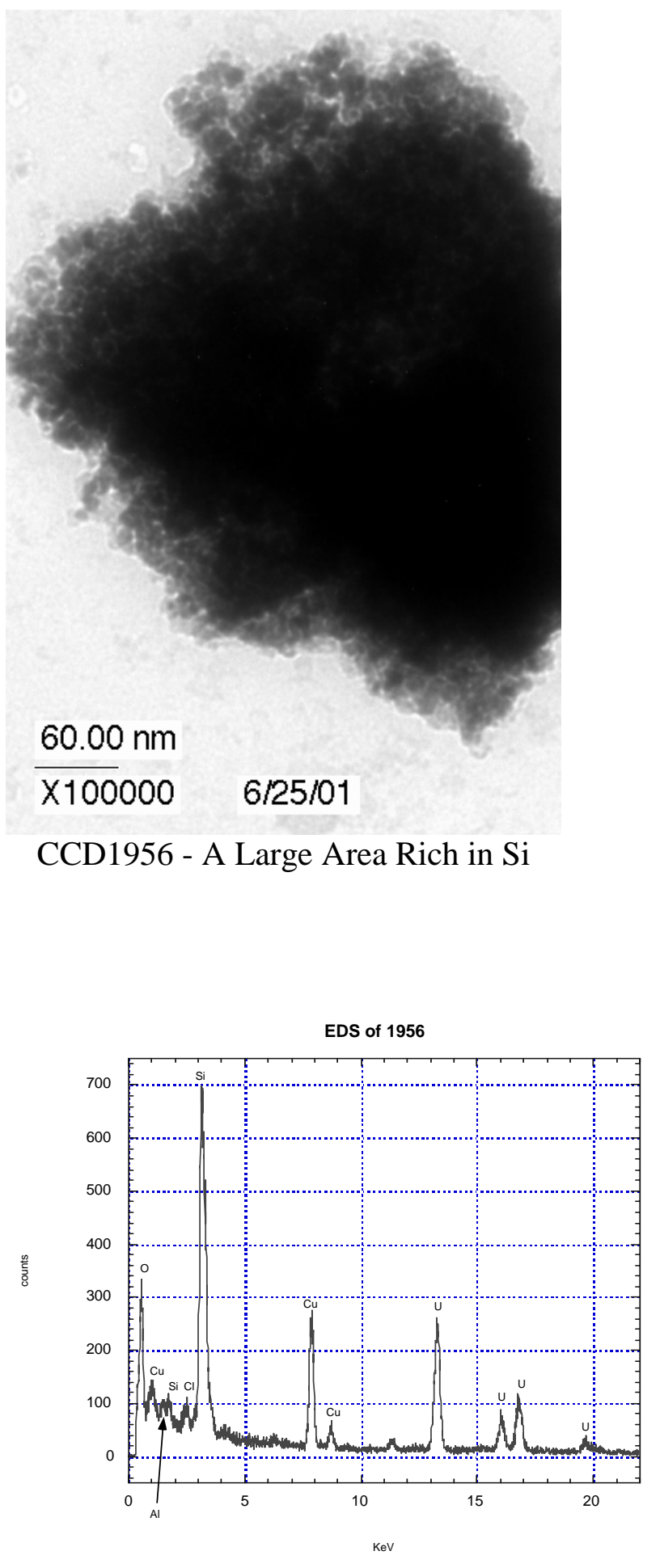

EDS of the Material in CCD 1956 

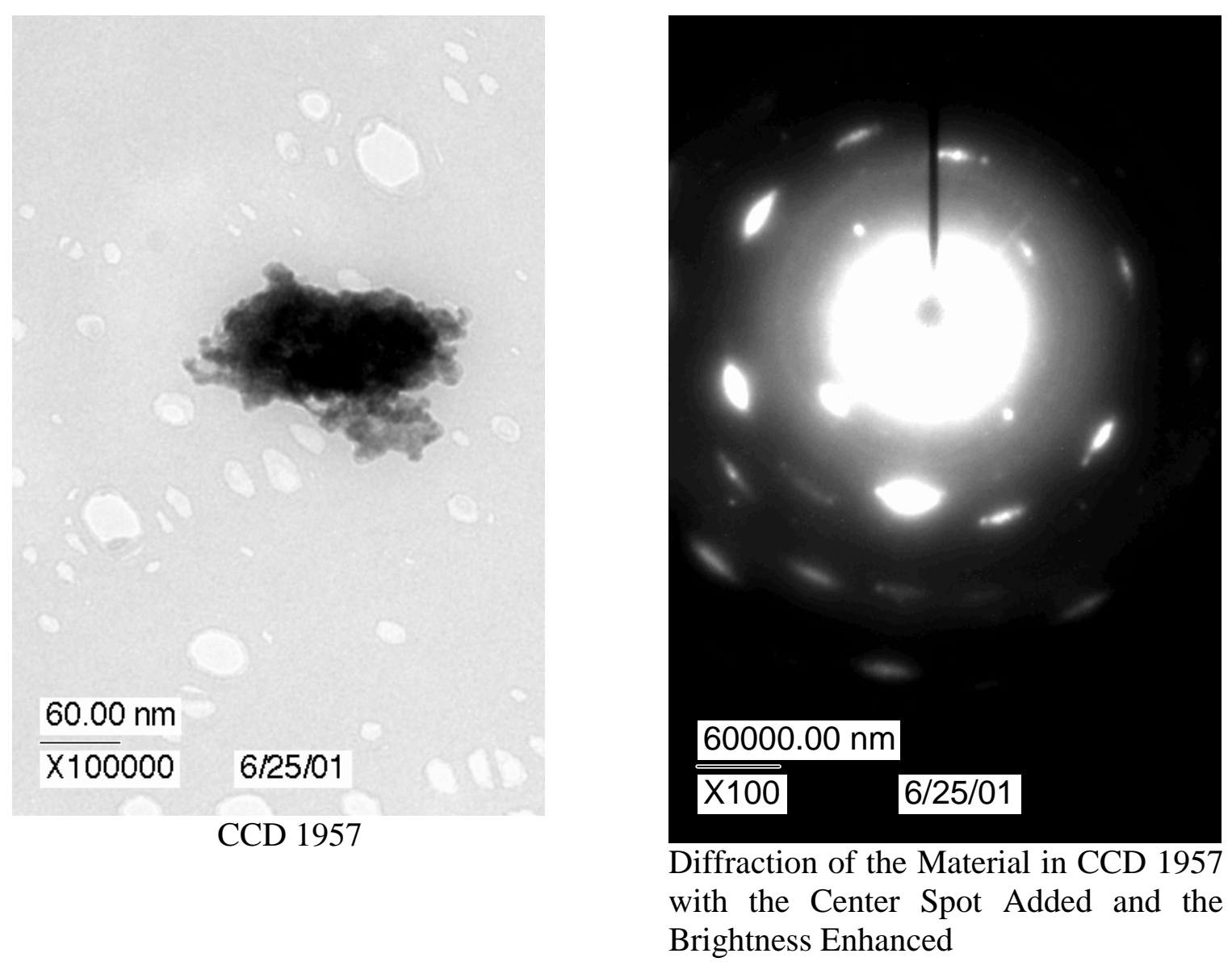

This diffraction data confirms that the material in CCD 1957 is $\mathrm{UO}_{2}$.

Diffraction from CCD Image k1957diff 100 Composite

\begin{tabular}{cccc}
\hline $\begin{array}{c}\text { Experimental } \\
2 \mathrm{Q}(1 / \AA)\end{array}$ & $\begin{array}{c}\text { Experimental } \\
\text { d-spacing }(\AA)\end{array}$ & $\begin{array}{c}\mathrm{UO}_{2} \\
\text { JCPDS-ICDD 5-550 } \\
\text { d-spacing }(\AA)\end{array}$ & $\begin{array}{c}\mathrm{UO}_{2.25} \\
\text { JCPDS-ICDD 9-206 } \\
\text { d-spacing }(\AA)\end{array}$ \\
\hline \multirow{2}{*}{4.5} & & 3.157 & 3.12 \\
6.53 & 2.79 & 2.735 & 2.71 \\
& 1.92 & 1.934 & 1.918 \\
& & 1.649 & 1.636 \\
9.1 & 1.38 & 1.579 & 1.567 \\
10.01 & 1.26 & 1.368 & 1.359 \\
& & 1.255 & 1.247 \\
11.73 & 1.07 & 1.223 & 1.215 \\
12.9 & 0.97 & 1.1163 & 1.047 \\
\hline
\end{tabular}




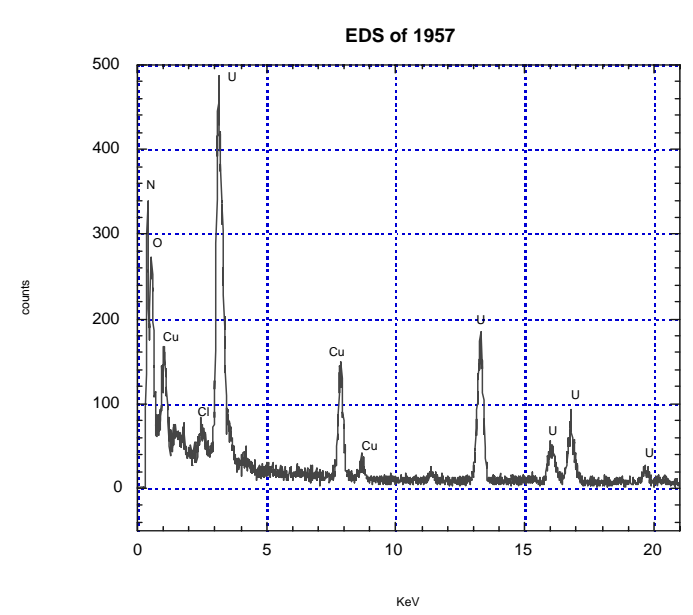

EDS of the Material in CCD 1957

Unfortunately, CCD 1958 and the associated diffraction patterns and EDS data was discarded due to excessively short exposure times and camera length.

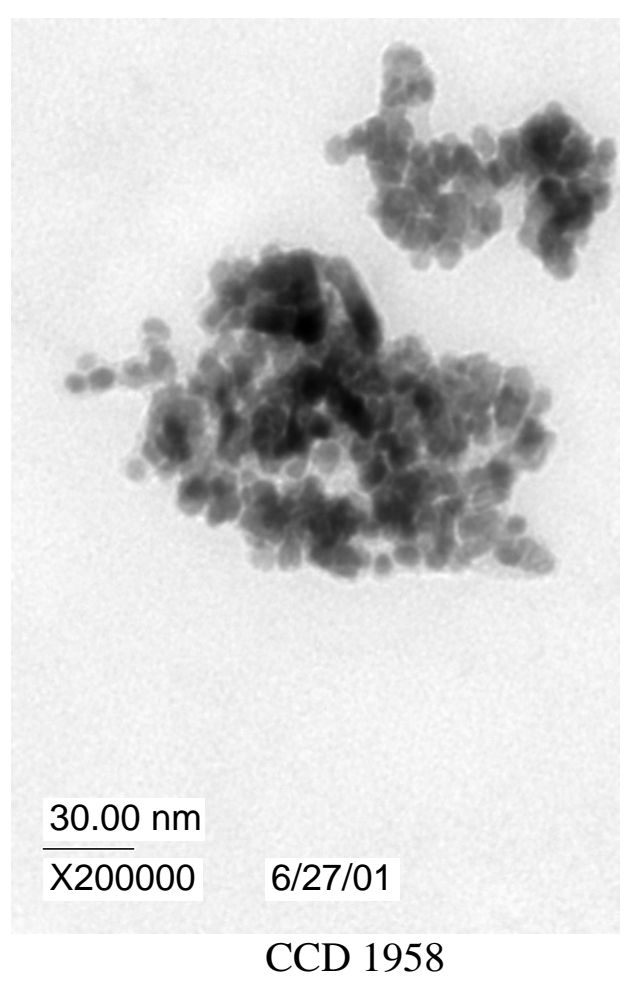

This is the diffraction pattern from the particles in CCD 1959 with the addition of the center spot to the pattern.

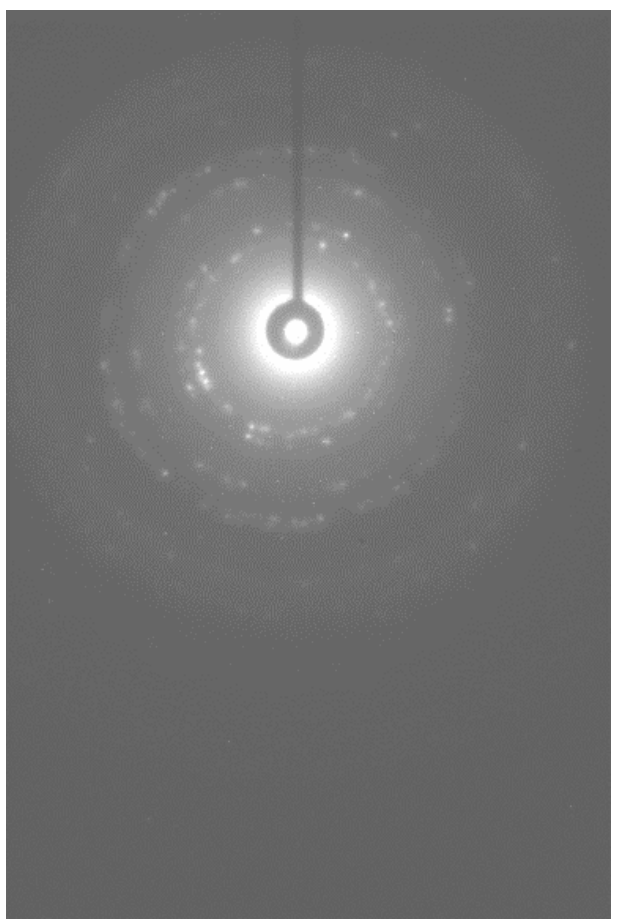


The diffraction data suggests a systematic shift but does confirm that the particles in CCD 1959 are $\mathrm{UO}_{2}$.

Diffraction from CCD Image k1957diff 100 Composite

\begin{tabular}{cccc}
$\begin{array}{c}\text { Experimental } \\
2 \mathrm{Q}(1 / \AA)\end{array}$ & $\begin{array}{c}\text { Experimental } \\
\text { d-spacing }(\AA)\end{array}$ & $\begin{array}{c}\mathrm{UO}_{2} \\
\text { JCPDS-ICDD 5-550 } \\
\text { d-spacing }(\AA)\end{array}$ & $\begin{array}{c}\mathrm{UO}_{2.25} \\
\text { JCPDS-ICDD 9-206 } \\
\text { d-spacing }(\AA)\end{array}$ \\
\hline 4.14 & 3.04 & 3.157 & 3.12 \\
4.93 & 2.55 & 2.735 & 2.71 \\
6.52 & 1.93 & 1.934 & 1.918 \\
& & 1.649 & 1.636 \\
7.99 & 1.57 & 1.579 & 1.567 \\
9.53 & 1.32 & 1.368 & 1.359 \\
10.59 & 1.19 & 1.255 & 1.247 \\
& & 1.223 & 1.215 \\
& & 1.1163 & 1.11 \\
11.79 & 1.06 & 1.0523 & \\
& & 0.9666 & \\
\hline
\end{tabular}

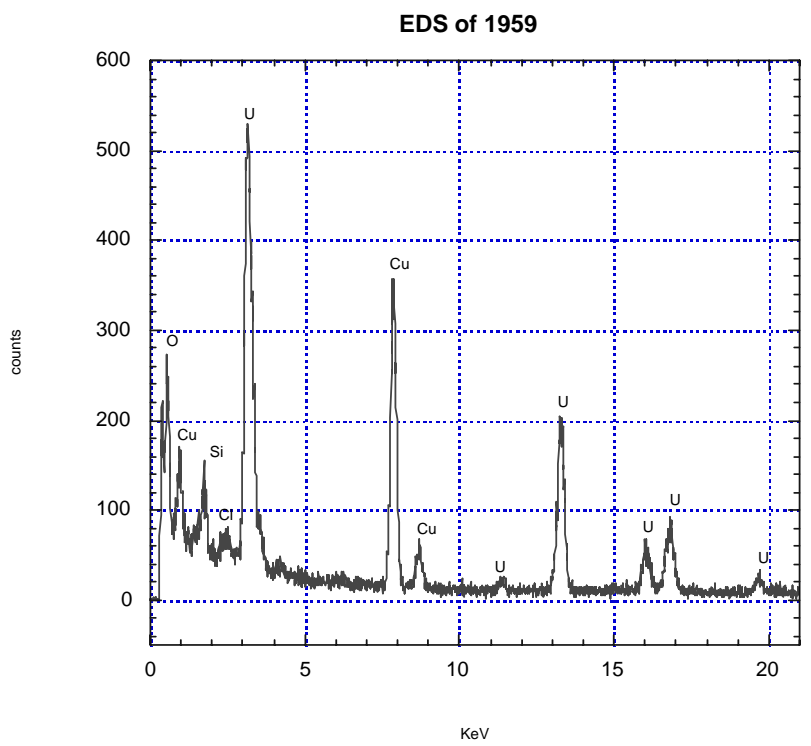

EDS of the Material in CCD 1959 


\section{Distribution for ANL-01/33}

Internal:

J. C. Cunnane

N. M. Dimitrijevic

W. L. Ebert

R. E. Einziger

P. A. Finn
J. A. Fortner

M. M. Goldberg

M. D. Kaminski (20)

D. Lewis

C. J. Mertz
R. T. Riel

Y. Vojta

TIS File

\section{External:}

DOE-OSTI

ANL-E-Library

ANL-W-Library

Chemical Technology Division Review Committee Members:

H. U. Anderson, University of Missouri-Rolla, Rolla, MO

A. L. Bement, Jr., Purdue University, West Lafayette, IN

R. A. Greenkorn, Purdue University, West Lafayette, IN

C. L. Hussey, University of Mississippi, University, MS

M. V. Koch, University of Washington, Seattle, WA

V. P. Roan, Jr., University of Florida, Gainesville, FL

J. R. Selman, Illinois Institute of Technology, Chicago, IL

J. S. Tulenko, University of Florida, Gainesville, FL

M. Ebner, Idaho National Environmental and Engineering Lab, Idaho Falls, ID

H. H. Loo, Idaho National Environmental and Engineering Lab, Idaho Falls, ID

C. Shelton-Davis, Idaho National Engineering and Environmental Laboratory, Idaho Falls, ID 